\title{
BALOGH ZOLTÁN
}

Személyes adatok gyưjtése és profilírozás az interneten 

Számítástudományi Tanszék

TÉMAVEZETŐ: RACSKÓ PÉTER, CSC

copyright (C) Balogh Zoltán 



\title{
BUDAPESTI CORVINUS EGYETEM
}

\author{
Gazdaságinformatika Doktori Iskola
}

Személyes adatok gyưjtése és profilírozás az interneten

Doktori értekezés

Balogh Zoltán

Budapest, 2017 



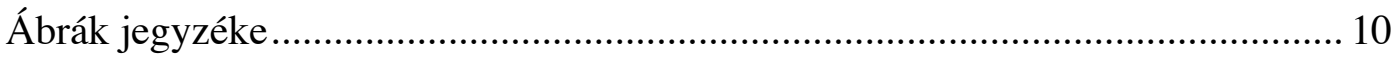

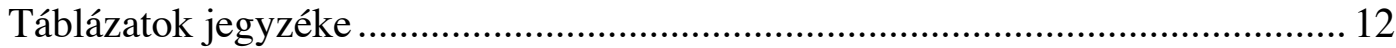

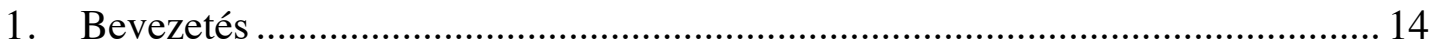

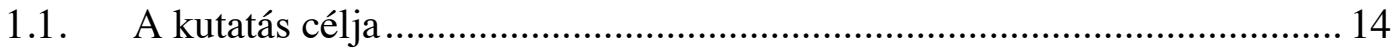

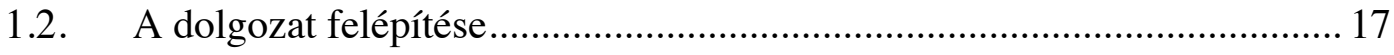

1.3. Az alkalmazott szemléletmód és az üzleti érték ........................................ 19

1.4. A szakirodalom áttekintése ...................................................................... 21

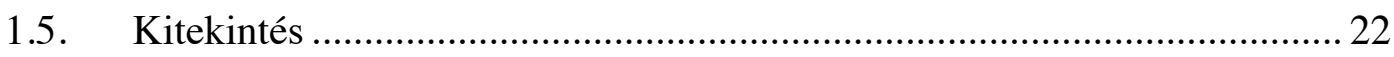

2. Anonimitás, adatvédelem …………………………………………………….... 24

2.1 Az anonimitás definíciója ........................................................................ 24

2.2 A személyes adatok védelme (privacy) ………………………………...... 25

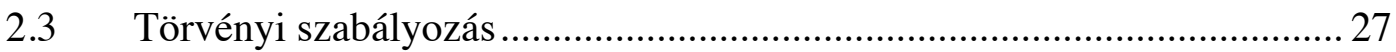

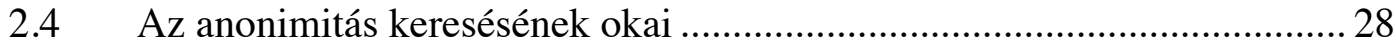

2.5 Az anonimitás elhagyásának következményei.............................................. 31

3. A látogatók azonosításának és követésének módszerei..........................................33

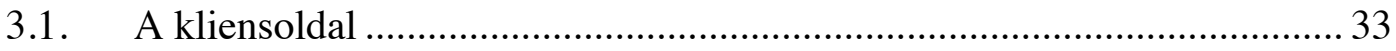

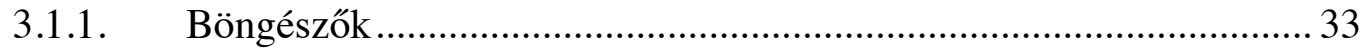

3.1.2. A munkamenet ............................................................................. 37

3.1.3. A kliens oldali adattárolás.................................................................. 38

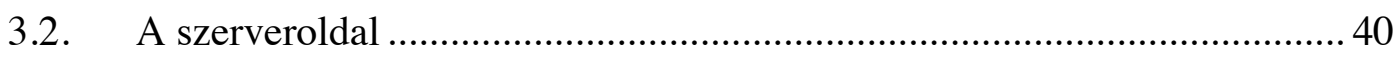

3.3. A böngészés folyamata ............................................................................ 42

3.3.1. A weblap megtekintése ………………………………………..... 42

3.3.2. A böngészés révén kinyerhetô adatok................................................. 42

3.3.3. A rendelkezésre álló adatok ............................................................. 45

3.3.4. A hozzáférhetố adatok …………………………………………...... 46

3.3.5. A felhasználói életút vizsgálata …………………………………....... 51 
3.4. Látogatók azonosításának és követésének módszerei.

3.4.1. A böngésző által szolgáltatott adatokból kinyert információ

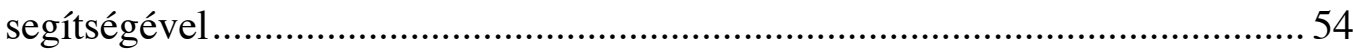

3.4.2. A viselkedés alapú nyomkövetés .................................................59

3.4.3. A látogató azonosítása és követése ................................................... 61

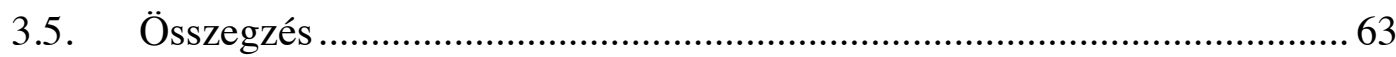

4. Az eszközböngészőkről begyújthető adatok jellemzői.................................... 65

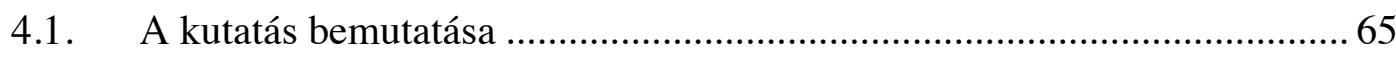

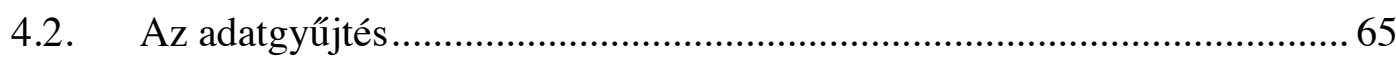

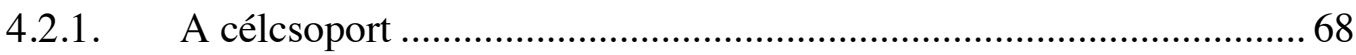

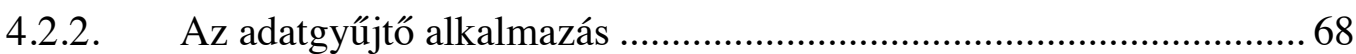

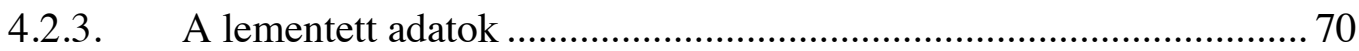

4.3. A bizonytalanság-csökkentő képesség mérőszáma ................................. 71

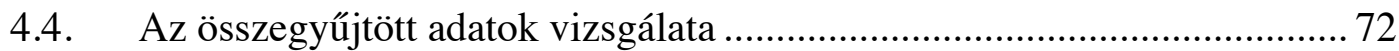

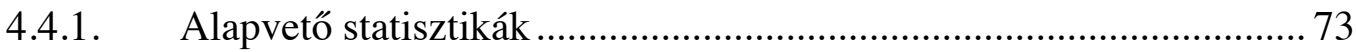

4.4.2. A lementett változók bizonytalanság csökkentő ereje ...................... 75

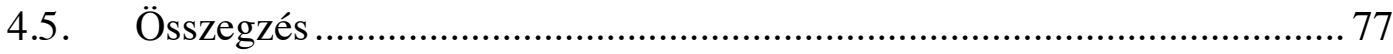

5. Az Egyetemi polgárok pszichológiai jellemzői adatvédelmi szempontból........ 79

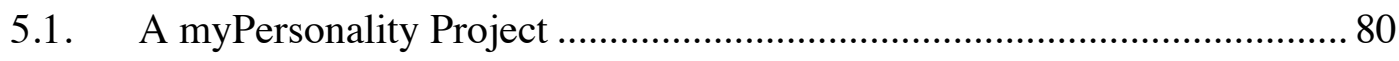

5.2. A Big 5 - személyiségi jellemzők …................................................ 81

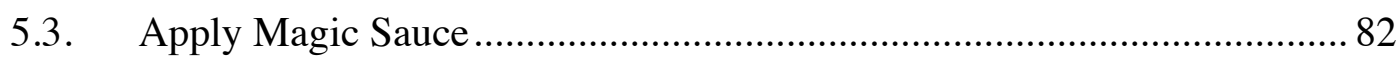

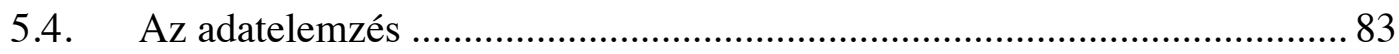

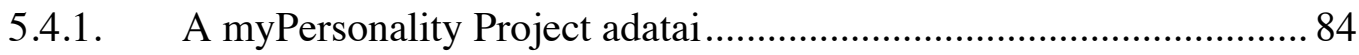

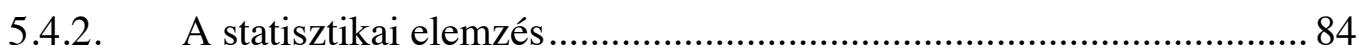

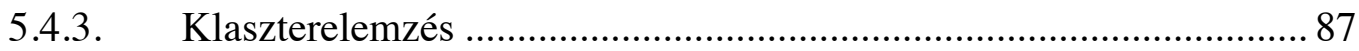

5.4.4. Az eredmények kiértékelése ........................................................ 95

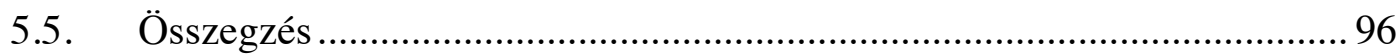


6. Személyes információ kinyerése webes adatokból .98

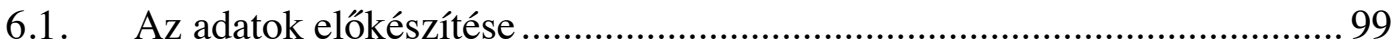

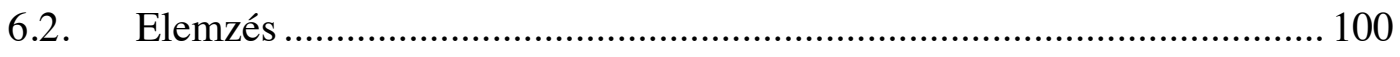

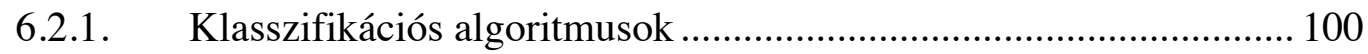

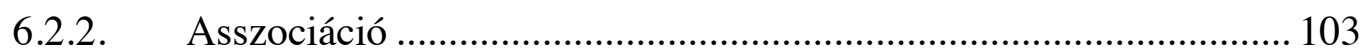

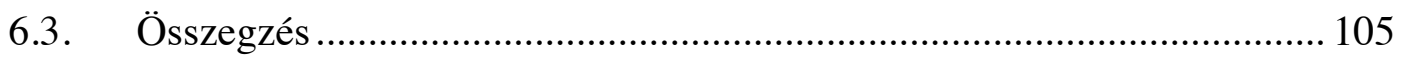

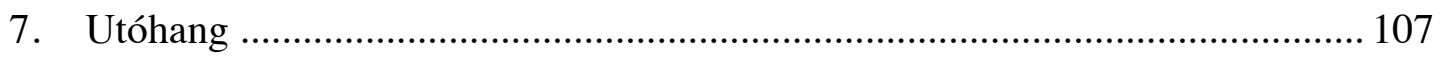

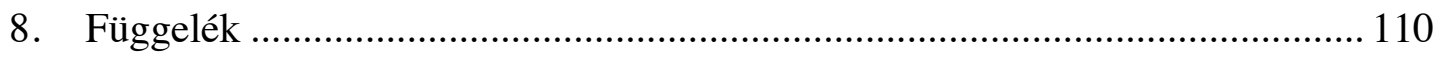

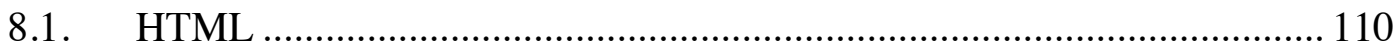

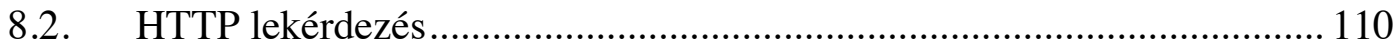

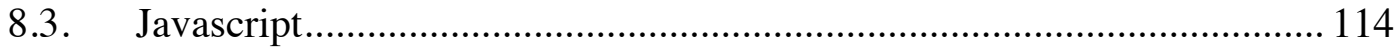

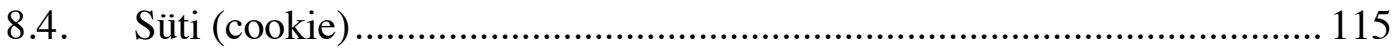

8.5. CSS3 és HTML5 képességek .............................................................. 118

8.6. Látogatók azonosításához használható kiemelt paraméterek elemzése ... 119

8.7. Adatgyưjtő alkalmazás ......................................................................... 124

8.7.1. Az alkalmazás múködése .......................................................... 125

8.7.2. Hozzáférhető adatok relevanciája és terhelése .............................. 127

8.7.3. A lementett adatok listája.......................................................... 132

8.7.4. A lementett adatok statisztikai jellemzői ..................................... 136

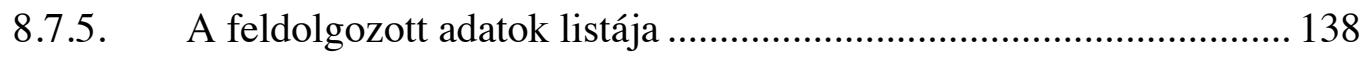

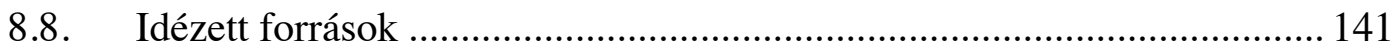

8.8.1. Tudományos szakirodalmi múvek ................................................. 141

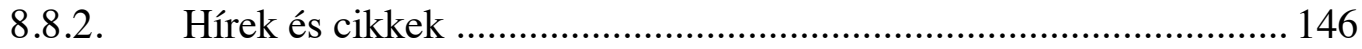




\section{Ábrák jegyzéke}

1. ábra: Filter bubble grafikus ábrázolása (Pariser, 2011) .................................... 31

2. ábra, az index.hu HTTP lekérdezés fejléce (saját felvétel) ................................... 36

3. ábra, A GMail nem múködik sütik használata nélkül (saját szerkesztés) .............. 38

4. ábra, követésre alkalmas technológiák fejlódése (saját) ........................................ 40

5. ábra: webszerver kapcsolata az adatbázissal és a böngészővel (Bhavin, 2014) ... 41

6. ábra, HTTP lekérdezés fejléce (saját felvétel) ..................................................... 41

7. ábra, Egy harmadik fél által írt alkalmazás engedélyeket kér a Facebook-tól (saját

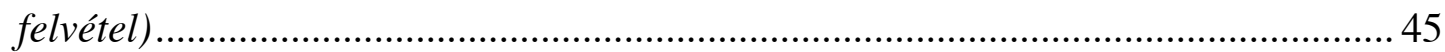

8. ábra, a látogató és az Internet közötti kapcsolat (saját szerkesztés) ..................... 46

9. ábra, a Chrome engedélyt kér a látogató földrajzi pozíciójához (saját felvétel)... 47 10. ábra, asztali operációs rendszerek piaci részesedése 2016-ban (NetMarketShare,

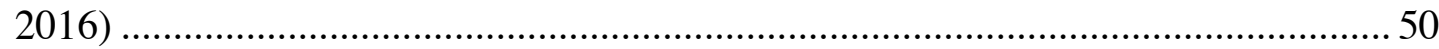

11. ábra, Egy webhely weblapjainak gráf formában történó ábrázolása (saját szerkesztés). 51

12. ábra, Azonosítás módszereinek egymáshoz való viszonya (saját szerkesztés)..... 53

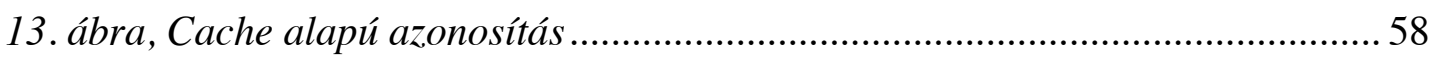

14. ábra: a földrajzi pozíciók város, utca és házszámra történó feloldása Pentaho-val

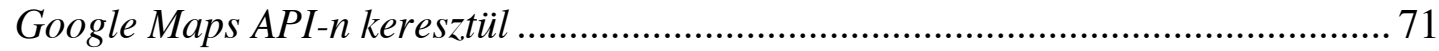

15. táblázat: Lementett változók bizonytalanság csökkentő ereje ............................ 76

16. táblázat: Lementett változók bizonytalanság csökkentő ereje ............................ 77

17. ábra: Apply Magic Sauce - Prediction API alcíme (The Psychometrics Centre,

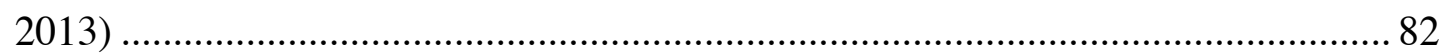

18.ábra: Facebook Like-okat személyiségi jegyekké feloldó Pentaho alkalmazás (saját szerkesztés). 84

19. ábra: Az intelligencia és az élettel való elégedettségét megjelenító scatterplot diagram 86

20. ábra: A klaszterek 3 dimenziós hisztogramja .................................................... 89

21. ábra: Hierarchikus klaszterelemzés dendrogramja ............................................ 94

22. ábra, URL szerkezete (saját szerkesztés) ......................................................... 110

23. ábra, A HTTP lekérdezés menete (Websiteoptimization.com, 2009) ................ 111

24. ábra, a WizzAir.hu föoldalának HTTP válasza (saját) .................................... 113

25. ábra, HTML DOM objektum kezelése Javascript-tel (saját szerkesztés) .......... 115 
26. ábra, szerver által küldött sütik (saját felvétel)

27. ábra, süti létrehozása Javascripttel és jQuery segítségével (saját) 116

28. ábra: Adatgyújtő alkalmazás megjelenése a Corvinus e-learning rendszerében (saját felvétel).

29. ábra: Adatgyújtó alkalmazás vázlatos múködése (saját szerkesztés)

30. ábra: Azonositásra használható eszközböngészóból kinyerhető paraméter és felvehetó értékei (saját szerkesztés) 


\section{Táblázatok jegyzéke}

1. táblázat: A Facebook különféle típusú hirdetéseinek átkattintási rátája............... 22

2. táblázat: 5 legelterjedtebb böngészö (W3Schools, 2017) .................................. 34

3. táblázat: Néhány ismertebb böngésző és megjelenítő motorja (Stanclift, 2008)... 35

4. táblázat: harmadik féltól lekérdezhetô paraméterek elönyei és hátránya .............. 48

5. táblázat: azonositásra használható paraméterek és azonosításuk tárgya ............. 55

6. táblázat: Apply Magic Sauce API-ja által visszaadott személyes adatok (The

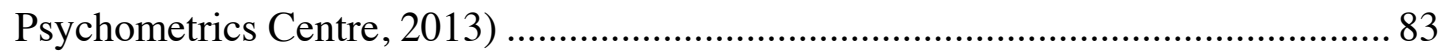

7. táblázat: A Big 5 jellemzóinek átlaga és 95\%-os konfidencia intervalluma ......... 85

8. táblázat: A Big 5 jellemzóinek átlaga és 95\%-os konfidencia intervalluma .......... 85

9. táblázat: A Big 5 jellemzóinek átlaga és 95\%-os konfidencia intervalluma ......... 85

10. táblázat: A Big 5 jellemzóinek átlaga és 95\%-os konfidencia intervalluma ....... 86

11. táblázat: A myPersonality Big 5 jellemzóinek ANOVA táblája ........................... 87

12. táblázat: A myPersonality politikai jellemzóinek ANOVA táblája ....................... 88

13. táblázat: A myPersonality családi állapot jellemzóinek ANOVA táblája............. 88

14. táblázat: A klaszter tagság kereszttáblája ......................................................... 88

15. táblázat: A Big 5 és a családi állapot klasztereinek ANOVA táblája .................. 89

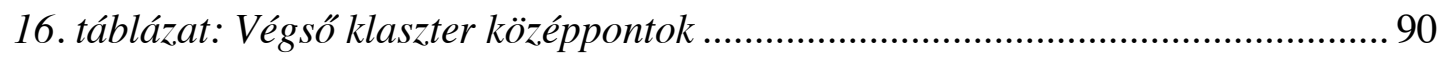

17. táblázat: Klaszterek kereszttáblája …................................................................ 90

18. táblázat: Big 5 klaszterek ANOVA táblája ........................................................ 91

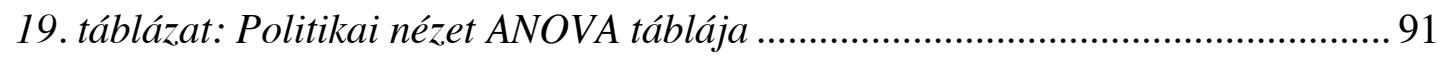

20. táblázat: Családi állapot ANOVA táblája ......................................................... 92

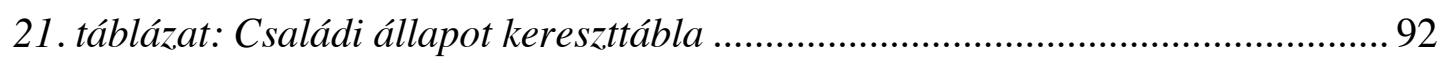

22. táblázat: A BIG5 és a családi állapot változóinak ANOVA táblája .................... 93

23. táblázat: Klaszter tagság ellenórzés ..................................................................95

24. táblázat: myPersonality Project adatainak K-középpontú klaszterei ................... 95

25. táblázat: a saját adatok K-középpontú klaszterei .............................................. 95

26. táblázat: az alkalmazott osztályozó algoritmusok által helyesen osztályozott változók százalékos aránya 102

27. táblázat: az intelligencia és az élettel való megelégedettség változókra alkalmazott klasszifikációs algoritmusok kimenete .... 103

28. táblázat: a talált szabályok bizonyossági (confidence) szintje rögzített bizonyosság és támogatottsági szint mellett 104 
29. táblázat: a talált szabályok bizonyossági (confidence) szintje rögzített bizonyosság és támogatottsági szint mellett ............................................................................... 105

30. táblázat: A GET és POST lekérdezés HTTP fejléce (saját) ............................... 113

31. táblázat: az SQL és a HTTP CRUD müveletei (Medic, 2014) .......................... 113

32. táblázat: kiemelt paraméterek elemzése …..................................................... 121

33. táblázat: a lementett paraméterek statisztikai jellemzói ................................... 137 


\section{BEVEZETÉS}

2013. március 12-én lett 25 éves az internet. Valószínúleg a HTTP protokoll és a HTML nyelv feltalálója Tim Berners-Lee sem gondolta akkoriban (Owen, 2014), hogy forradalmasítani fogja az emberi kommunikációt. Ő maga 2013. március 18-án megkapta az Erzsébet Királynő Mérnöki Díjat (Queen Elizabeth Prize for Engineering) találmányáért. A statisztikák szerint 2012-ben az emberiség több mint egyharmada használta az Internetet és 2016-re az éves forgalmazott adat mennyisége elérte az 1 zettabyte-ot is (Cisco, 2014). 2014-ben hozzávetőlegesen 600 millió weblap létezett, melyek végérvényesen megváltoztatták az emberi információszerzés és tartalommegosztás módját.

A web fejlődés egyik mérföldkövének a közösségi oldalak megjelenését tekinthetjük, a legjelentősebbnek számító közösségi háló, a Facebook megreformálta az információ elérésének módját. (Jeffrey, 2012) 2017 februárjában a közösségi hálónak több, mint 1 milliárd 860 millió felhasználója és több, mint 1 milliárd 150 millió látogatója volt naponta. (Zephora - Digital Marketing, 2017)

\subsection{A kutatás célja}

Egy 2015-ös felmérés szerint a britek többsége a mindenki számára hozzáférhető, cenzúramentes és anonim internet mellett teszi le a voksát. (Healy, 2015) Ahogy az internet a hétköznapjaink részévé vált, a weboldalakat megjelenítő alkalmazások - a böngészők - fejlődése is felgyorsult. Ez lehetővé tette a weboldalak számára, hogy egyre több adatot érjenek el a látogatóikról. Az online tartalmak megtekintésével megismerhetővé vált a látogatók fogyasztóinak preferenciái és böngészési szokásai. Ezen adatok elemzésével a látogató személyre szabott tartalmat kaphat és ezzel egyidejúleg felfedhetôvé válnak a személyes jellemzői is. A személyre szabott tartalmak következtében megjelent a „filter bubbles” jelensége, amely során a felhasználó az észlelt tulajdonságaihoz illő tartalmakhoz fér hozzá, viszont nincs kontrollja afelett, hogy mi az, amit fogyaszthat és mi az, amit nem. A felhasználók profilozása miatt a kezdeti anonim web ma már nem az.

A látogatók preferenciáinak megismerését követően megjelentek az online ajánlórendszerek. Például, az amerikai online músorszóró vállalat, a Netflix ajánlórendszere hozzávetőlegesen az esetek 80\%-ban befolyásolja a látogatókat a tartalmak fogyasztásában. (Carlos \& Neil, 2015) Emiatt nem meglepó, hogy a cég 
igencsak érdekelt az általuk használt algoritmusok hatékonyságának növelésében. Emiatt 2006 és 2009 között 1 millió dolláros Netflix Díjjal ösztönözték vállalkozó szellemú vállalkozókat az ajánlórendszer hatékonyságának javítására. A győztes csapat által kidolgozott algoritmus hatékonyságában 10,06\%-kal múlta felül a Netflix által használtat. (Lohr, 2009) Az internetes szolgáltatók komoly erőfeszítéseket tesznek ügyfeleik profiljának minél pontosabb meghatározására, mert ez számukra versenyelőnyt, sokszor pedig a pályán maradás feltételét jelenti. Nyugodtan kimondhatjuk, hogy ami az interneten megismerhető, azt a szolgáltatók meg is fogják ismerni. A dolgozatban azt kutattam, hogy melyek az interneten egy-egy felhasználóról legális eszközökkel kibányászható adatok és az adatokból levonható következtetések határai.

Az információszerzés és felhasználás területén jelenleg paradigmaváltás figyelhető meg: amíg korábban a felhasználók pusztán a korszerű keresőmotorok képességeit kihasználva találták meg a számukra releváns információt, mára a keresőmotor használatán felül az online szolgáltatások a látogatók preferenciájának megismerésével képesek eldönteni, hogy egy adott tartalom a látogató számára érdekes lehet-e, azaz a tartalom jellemzőit és a látogató preferenciáit összevető algoritmus dönti el, hogy az a látogató számára érdekes-e. A preferenciákat összeállító, profilozó algoritmust használó oldalak (keresőoldalak, hírportálok és közösségi oldalak) használatával a látogatók implicit módon hozzájárulnak a detektálható jellemzőik gyưjtéséhez, majd ezen adatok alapján az oldal tartalmakat ajánl számukra fogyasztásra. A weboldalak által használt ajánlórendszerekről a látogatók sok esetben nem tudnak és használatuk mellőzésére az esetek többségében nincs mód.

Kutatásaim során arra kerestem a választ, hogy a weboldalak számára mely hozzáférhető adatokból lehetséges a látogató tulajdonságaira következtetni, mely adatok alkalmasak a profilok összeállítására és ez hogyan történik. Kutatásaimat az alábbiak szerint építem fel:

Az első kutatási cél a nem professzionális, egy domain alól elérhető weboldalak $^{1}$ vizsgálata. Exploratív kutatás keretében az internetezéshez használt

\footnotetext{
${ }^{1}$ Általában az egy domain alatt elérhetô weboldalak képesek hozzáférni a böngészéshez használt eszköz, a rajta lévő operációs rendszer és a böngésző valamennyi tulajdonságához (céges weboldak, hírportálok, blogok, webáruházak), feltétel, hogy nincs az oldalnak más weboldalakba beépüló adatgyújtő modulja, amellyel a látogatók preferenciáit vagy böngészési jellemzőit lehetséges feltérképezni, a látogatók nem regisztrálják magukat az oldalra, amely esetben a beazonosítás triviálissá válna
} 
böngészőkből, valamint az internetezéshez használt hardverről és annak szoftverkörnyezetéből kinyerhető adatokat elemezve következtettem a felhasználó személyes jellemzőire. Az elemzési fázisban a felhasználók és személyes paramétereik között csak triviális kapcsolatot sikerült kimutatni, a magukat szándékosan felfedni nem kívánó látogatók esetében nem sikerült személyes jellemzőket megállapítani. Megvizsgáltam a böngészók számára hozzáférhető paraméterek bizonytalanságcsökkentő erejét is. Felmértem az egy domain alól elérhető weboldalak és közösségi oldalak látogatóikról elérhető adatok mennyiségét és minőségét. A látogatókról összegyújtött adatok bizonytalanság-csökkentő képessége megmutatja, hogy a mintán belül mekkora valószínúséggel található meg egy egyed, és összehasonlíthatóvá válik a kinyert paraméterek különböző csoportosításainak információhordozó ereje.

A második kutatási cél a Budapesti Corvinus Egyetem közösségi oldalak által összegyújtött, kinyilvánított preferenciákból kinyert személyes tulajdonságok alapján a látogatók csoportosítása, majd a kapott csoportok összevetése a myPersonality Project (Stillwell \& Kosinski, 2012) során összegyújtött adatokból készített klaszterekkel. Azt mutatom be, hogy a felhasználók által önként szolgáltatott adatokból hogyan lehet személyiségre vonatkozó következtetéseket levonni. Természetesen az adatokat felhasználás előtt anonimizáltam. A kutatás során a Facebook-tól letöltött egyénekhez köthető „Like” adatbázist elemeztem.

A közösségi hálózatok aktív tagjai az online tartalmakról alkotott tetszésüket a „Like” ${ }^{2}$ gombra történő kattintással is kifejezhetik. Ez a látogatókhoz köthetô információ az közösségi hálózatokon elérhető. A kutatás során a Budapesti Corvinus Egyetem polgárainak „Facebook Like”-jait elemeztem pszichológiai API segítségével (Kielczewski, 2017), majd az egyéneket a kapott személyes jellemzőik alapján nem felügyelt tanulási módszerekkel klasztereztem. A kutatás szintén feltáró jellegú, a Budapesti Corvinus Egyetem polgárainak és a myPersonality Project résztvevőinek a pszichológiai API által visszaadott személyes tulajdonságokból képzett látogatói klaszterek közötti különbségeket mutatja be.

A harmadik kutatási célom annak kikísérletezése volt, hogy hogyan lehet a látogatók nem személyes jellemzőiből következtetni személyes jellemzőikre. Az Apriori algoritmus (Gautam, Ghodasara, \& Parsania, 2014) használatával a Budapesti

\footnotetext{
${ }^{2}$ Facebook Like gomb (2010 második negyedév): a felhasználók kifejezhetik a tetszésüket egy weben található tartalom iránt. Ezzel a lépéssel azokról a weboldalakról is képes a Facebook adatokat gyújteni a felhasználóiról a közösségi oldal meglátogatása nélkül
} 
Corvinus Egyetem polgárainak e-learning környezetbeli viselkedését elemezve arra kerestem a választ, hogy a látogatók mely személyes tulajdonságaikra lehetséges online viselkedésükből következtetni.

A dolgozat további, a kutatás technikai részét tartalmazó részében bemutatom a különböző típusú weblapok által hozzáférhető adatokat és a belőlük kinyerhető, a látogatókra vonatkozó személyes jellemzőket. Amíg az egy domain alól elérhető weboldalak a látogatókról csekély személyes információt képesek kinyerni, egy kiterjedt, beépülő modulokkal rendelkező oldal ${ }^{3}$ átfogó profilt képes építeni a látogatói preferenciáiról, érdeklődési körükről és szokásairól. (Szommer, Balogh, \& Racskó, 2014).

A látogatók személyes tulajdonságuk alapján történő csoportokba rendezése üzletileg jól hasznosítható eredményt hoz, ui. az egyes csoportoknak célzott reklámok küldhetőek. A kezdetek óta a Facebook egyik üzleti stratégiai alappillére a közösségi hálózatokban rejlő hirdetési felület adta lehetőség kiaknázása. (Jeffrey, 2012) A weboldalak látogatói az üzlet szempontjából meghatározó tulajdonságaik alapján csoportosíthatóak.

Az üzleti szempontból megfelelő minőségû felhasználói profilok kialakításához elengedhetetlen a látogatókról gyűjtött adatok időközönkénti frissítése. Emiatt és a felhasználók megtartása érdekében a Facebook folyamatosan fejleszti termékeit ${ }^{4}$ és azon dolgozik, hogy a felhasználóiról egyre több és pontosabb információt szerezzen be be $^{56}$ (Zuckerberg, 2015).

\subsection{A dolgozat felépítése}

A dolgozatom központi témáját - a kibertér szereplőiről elérhető információk minőségi jellemzését - három saját kutatás segítségével mutatom be a következő bekezdésekben bemutatott vezérfonal mentén.

\footnotetext{
${ }^{3}$ A kiterjedt hálózattal rendelkező weblapok csoportja (közösségi hálózatok, hirdetési ügynökök stb.) olyan weboldalakat foglal magában, amelyek vagy a moduljait más webloldalakba beépítették és amelyek képesek az oldalt látogatókról adatokat küldeni a beépülő modulok gazdáinak, amelyek révén lehetséges a látogatók preferenciáinak feltérképezése.

${ }^{4}$ Facebook Home (2013 első negyedév) alkalmazás/operációs rendszer kiegészítő modul megjelenése Androidra, melynek segítségével egy átlagos weblap vagy okostelefon alkalmazáshoz képes jóval több mélyebb szinten ágyazódik lesz része a mobil operációs rendszernek és több adathoz is hozzáfér a felhasználóról

${ }^{5}$ Egérmozgás figyelés (2013 október): bizonyos felhasználók csoportjának egérmozgásának figyelése (Rosenbush, 2013) amelyből kinyert adatok segítségével értéknövelt szolgáltatás nyújtása

${ }^{6}$ Fejlődő országok területén Internet szolgáltatása drónok segítségével (2015. március) Mark Zuckerberg bejelentette, hogy a fejlődő országokba drónok segítségével fogja az Internetet szolgáltatni (Camilla, 2015)
} 
Az empirikus, irodalmakat áttekintő részben az online anonimitás témakörének fogalmait definiálom, elemzem az elhagyásának következményeit, végül meghatározom a dolgozatban alkalmazott személeletmódomat. (Xu, Dinev, \& Smith, 2011)

A technikai bevezetô részben a látogatók azonosításának és követésének módszereit a webes böngészés alapjaitól kezdve strukturált formában foglalom össze, ezt követően a látogatókról a böngészőn keresztül kinyerhető tulajdonságokat rendszerezve közlöm, majd azok hozzáférhetőségének módját vizsgálom.

Az elméleti felvezetés után következik a saját kutatásaimat leíró rész, amelyekben a magukat felfedó és a magukat felfedni nem kívánó látogatókat egyaránt vizsgálom. Mindhárom kutatás közös jellemzője az közös adatgyújtés, amelynek részletes leírása a $4.2 \mathrm{Az}$ adatgyújtés részben olvasható.

A látogatók beazonosíthatóságának elemzése igen aktuális téma. Rengeteg publikáció született a témában, amelyeknek jelentős részének szerzői a HTTP szerver log-okban kutatva keresi a látogatóhoz tartozó munkameneteket minták után kutat. A Myriam Abramson és David W. Aha User Authenticaion from Browsing Behaviour címú publikációjában leírt algoritmus a szerver log-okban keresi az egyes felhasználóra jellemző mintákat. (Abramson \& Aha, 2013). Dominik Herrmann, Christoph Gerber, Christian Banse és Hanness Federrath „Analyzing Characteristic Host Access Patterns for Re-Identification of Web User Sessions" írásában Bayes osztályozó algoritmus segítségével keresi a különböző felhasználókhoz tartozó munkameneteket, hasonlóan az Iváncsy Renáta és Juhász Sándor által írt „Analysis of Web User identification Methods" múben elemzett cookie nyomkövetés elemzéshez. (Iváncsy \& Juhász, 2007) A 4. Az eszközböngészókről $l^{7}$ begyújithetô adatok jellemzối fejezetben leírt szintén a weboldalak számára hozzáférhető adatokból táplálkozva igyekeztem a felhasználókat beazonosítani és tulajdonságaikra következtetni, valamint a felhasznált paraméterek bizonytalanság-csökkentő erejét vizsgáltam.

A Budapesti Corvinus Egyetemi polgárok pszichológiai jellemzóinek átlagtól való eltérései címú kutatás során az egyetemi polgárok összegyújtött Facebook Likejait elemeztettem a myPersonality Project pszichológiai API-jával, majd a kapott

\footnotetext{
${ }^{7}$ Az eszközböngésző egy általam bevezetett fogalom egy konkrét böngésző alkalmazás egy példánya, amelyet az egyén a weboldal eléréséhez használt egy internetképes eszközén. Ezáltal lehetséges a különböző internetezésre alkalmas eszközökön található böngésző fajta és egy konkrét eszközön található konkrét böngésző megkülönböztetése.
} 
eredményeket összevetettem más országok eredményeivel. A kutatás kiegészíti Dr. Michal Kosinski és Dr. David Stillwell myPersonality Project-tel kapcsolatos kutatásait.

Az Egyetemi polgárok pszichológiai jellemzói címú kutatásban a látogatók nem személyes jellemzőiből következtetek a személyes jellemzőikre.

A kutatásaim során átfogó képet mutatok be a különböző méretű és kiterjedésú weboldalak látogatói adataihoz való hozzáférésről, valamint ezen adatokból kinyerhető információ minőségéről. Az eszközböngészőkről begyújthető adatok fejezetben felmérem az egy domain alól elérhető weboldalak képességeit, a Budapesti Corvinus Egyetem polgárainak pszichológiai jellemzői fejezetben a kiterjedt hálózattal rendelkező oldalak (pl: közösségi hálózatok) képességeit elemzem.

\subsection{Az alkalmazott szemléletmód és az üzleti érték}

A webet használó közösség tagjai előszeretettel használják a mindenki számára hozzáférhető „ingyenes” online szolgáltatásokat: „ingyenes” tartalmakat fogyaszthatnak, kommunikálhatnak ismerőseikkel vagy tartalmakat oszthatnak meg. Ezen szolgáltatások használatával a felhasználók önként fedik fel sokszor felelőtlenül magánéletük minden egyes mozzanatát, de elvárják az online szolgáltatásoktól, hogy védve legyenek a rosszakarók ellen. Az üzleti érdekek azonban az online anonimitás felszámolását sürgetik, emiatt az elmúlt néhány a jelentősebb online informatikai szolgáltatók sorra jelentették be, hogy nem támogatják többé az anonim felhasználókat.

Mark Zuckerberg a Facebook alapítójának testvére Randi Zuckerberg, a Facebook marketing igazgatójának nyilatkozata szerint az anonim felhasználókból nem lehet pénzt csinálni (Chen, 2011) és a jövőben folytatni fogják a harcot az online anonimitás felszámolásáért. A közösségi oldalak ilyen mértékú terjedésének kétségkívül vannak hátrányai is: külön-külön többet tudnak rólunk, a felhasználókról, mint az FBI és a CIA együttvéve.

2012. januárjában a Google bejelentette az új adatvédelmi irányelveit, amelynek értelmében a Google által birtokolt online szolgáltatások ezt követôen megoszthatják a felhasználókról gyújtött adatokat egymás között. ${ }^{8}$ Ezzel a lépéssel a

8 Ez a gyakorlatban azt jelentheti, hogy a délután egykor Budapesten tartózkodó személyt figyelmeztetheti a Google, hogy induljon el a délután 16:00-kor kezdődo debreceni megbeszélésére egy fél órával korábban, mert az M3-as autópályán baleset történt, amennyiben a találkozót felvette a Google Naptárába. 
Google emelt szintű szolgáltatást képes nyújtani a felhasználói számára, de többet is fog tudni a használói cselekedeteiről és szokásairól.

„It will be very hard for people to watch or consume something that has not in some sense been tailored for them."

Eric Schmidt, Google

Az anonimitás témakörében az informatikával foglalkozó óriások állásfoglalása mára többé-kevésbé eldőlt. Az utóbbi években egymást követően jelentették ki, hogy a jövő igenis a személyre szabott tartalmaké lesz. Ez pedig azt vonja maga után, hogy az általuk üzemeltetett oldalakon szükséges a látogatók azonosítása és követése. Ezáltal személyre szabott tartalmakat és reklámokat küldhetnek számukra.

„A squirrel dying in front or your house may be more relevant to your interests right now than people dying in Africa."

Mark Zuckerberg, Facebook

Az üzleti érdekek következtében tehát nem az anonimitásra való törekvés a fó elv a weboldalak kialakítása során, hanem az, hogy a felhasználókról minél több információt érjenek el. Emiatt egyre jelentősebb különbség van az közösségi hálók felhasználói által szándékosan közzétett adatok és a róluk ténylegesen az interneten elérhető adatok között.

Egyes vélemények szerint az anonim kommunikáció jelenléte veszélyezteti a társadalom alappillérét: az elszámoltathatóságot és a felelősségre vonhatóságot. (Davenport, 2002)

Évente egyre több időt töltünk az online világban, emiatt a nekünk szóló reklámok is követnek minket oda. Az online világban feladott hirdetések abban különböznek a valós életbeli, hogy a hirdetés feladójának bővebb lehetôsége van információt szerezni a hirdetést megtekintő személyéről. A hirdetők célja az, hogy minél több és relevánsabb információkat érjenek el a hirdetés megtekintőjével kapcsolatban. Minél több adat elérhető a látogatókról, annál pontosabb képet kapnak róluk, feltárulnak a szokásaik, vágyaik és ízlésük.

Kutatásaim során nekem is az a célom, hogy a látogatókról minél több és értékesebb információt nyerjek ki. A dolgozatom hangvétele magán hordozza a tanulmányaim során felvett gazdaságinformatikusi szemléletmódot, amelyet Cser László az alábbi módon definiált: 
„A gazdaságinformatika a közgazdasági és az informatikai tudományok ismereteinek egyfajta kombinációja. A fogalom az üzleti szférában és a gazdálkodási területeken kezelt szociotechnikai rendszereket, az emberek és gépek által fejlesztett, illetve kezelt információ- és kommunikációrendszereket jelenti. A középpontban a gazdasági/üzleti feladatok támogatása áll.” (Cser, Nagyné Polyák, \& Németh, Informatikai Alapok, 2007)

\subsection{A szakirodalom áttekintése}

„The 21 st century... when deleting history is more important than making it...?”

(Smart, 2013)

A feldolgozott irodalmat az irodalomjegyzékben először a tudományos jellegük szerint csoportosítva, ezen belül pedig szerző szerinti $\mathrm{ABC}$ sorrendben közlöm, az alábbi kategóriákba sorolva:

- tudományos szakirodalomi múvek: szakkönyvek, konferenciaközlönyökben vagy kiadványokban megjelent publikációk, cikkek

- hírek és cikkek: nem a nyomtatott sajtóban megjelent cikkek, közlemények vagy leírások

Az elméleti részek témája az online anonimitás és a privacy fogalmához kapcsolódik, a gyakorlati részhez pedig az adatgyújtés és az adatok feldolgozása során használt technológiák és algoritmusok szakirodalma tartozik. A feldolgozott irodalmak tehát az alábbi kategóriák valamelyikébe sorolhatók be:

- Anonimitás/privacy fogalmát

○ A törvényi hátterét érintő

- Közösségi hálózatokról szóló

- Webes technológiákat taglaló

- Adatbányászati algoritmusokkal foglalkozó

Az anonimitással foglalkozó irodalom feldolgozása során a definícióból kiindulva fejtegetem az anonimitás fenntartásának okait. A téma tárgyalása alkalmával kitérek a magyar, európai és az amerikai törvényi háttérre. Ezt követően áttekintem a különféle embertípusok anonimitáshoz való kapcsolatát és az anonimitás elhagyásának következményeit. 
A webes technológiákat taglaló irodalom fóként a 3. A látogatók azonositásának és követésének módszerei fejezetben jelenik meg, hiszen ez a fejezet foglalkozik a téma technológiai részével, az adatbányászati algoritmusokkal pedig a 6 . Személyes információ kinyerése webes adatokból fejezet.

\subsection{Kitekintés}

A bevezetés utolsó alfejezetében néhány - többségük a Facebook-kal kapcsolatos - az internetes anonimitás jövőjét befolyásoló cikket emelek ki.

Látva a Facebook sikerét az elmúlt években sok közösségi oldal látott napvilágot, amelyeknek alapvetôen nem az a célja, hogy a Facebook felhasználók zömét magukhoz csábítsák, hanem a már jelenlévő sikeres közösségi oldalak pozitívumait és az újonnan felmerült felhasználói igényeket szem előtt tartva fedjenek le egy-egy részpiacot. Az új beszállók célja, hogy kihasítsanak maguknak egy szeletet az online reklámpiaci tortából.

Az iparági átlagos átkattintási ráta $\left(\mathrm{CTR}^{9}\right)$ az összes hirdetési formátumra 0,06\% (Chaffey, 2015), ehhez képest a Facebook átkattintási rátája 2013-ban hirdetéstól függően $0,02 \%-3,20 \%$ is lehet (Salesforce, 2013).

\begin{tabular}{|l|c|}
\hline \multicolumn{1}{|c|}{ Hirdetés típusa } & CTR \\
\hline Külső weboldalon lévő hirdetés & $0,02 \%$ \\
\hline Alkalmazás & $0,04 \%$ \\
\hline A felhasználók idővonalán megjelenő írás & $2,03 \%$ \\
\hline $\begin{array}{l}\text { Szponzorált helyról történő felhasználói } \\
\text { bejelentkezés }\end{array}$ & $3,20 \%$ \\
\hline
\end{tabular}

\section{1. táblázat: A Facebook különféle típusú hirdetéseinek átkattintási rátája}

Ennek ellenére néhány statisztika szerint a fiatal korosztályban a Facebook már nem számít menőnek, mivel azon már a szüleik és nagyszüleik is regisztráltak. (Christina, 2013) Emiatt a Facebook elkezdte felvásárolni azokat az online szolgáltatásokat, amelyeket a fiatalok előszeretettel használnak, például az Instagram és a Whatsapp. Valamint 2015. márciusában Mark Zuckerberg bejelentette, hogy már tesztelik az internetet szórni képes drónokat, amelyeket a fejlődő országokban szeretnének bevetni a közeljövőben. (Camilla, 2015)

\footnotetext{
${ }^{9}$ click through rate - átkattintási ráta: kattintásra jutó megtekintések száma
} 
A trendek abba az irányba mutatnak, hogy a webes technológiák - HTML5 és Javascript API ${ }^{10}-\mathrm{k}$ - fejlődésével az online alkalmazások számára egyre több adatot képesek elérni a látogatók által használt eszközökről. Az összegyújtött felhasználóhoz rendelt adatok a közösségi oldalak API-jainak használatával harmadik fél számára kinyerhetô a felhasználók hozzájárulásával.

A közösségi hálózatok piacán kiélezett verseny zajlik a felhasználókért, a Facebook igyekszik a jelenlegi 1,8 milliárdos felhasználóbázisát még tovább duzzasztani, valamint a világ jelentős részén ${ }^{11}$ az egyeduralmát hosszútávon bebiztosítani, amihez a HTML nyelv és a futtató platformok fejlődése nagyban hozzásegít, mivel rajtuk keresztül egyre több adatot hozzáférhető a felhasználókról.

\footnotetext{
${ }^{10}$ Application Programmers Interface: egy program azon eljárásainak (szolgáltatásainak) és azok használatának dokumentációja, amelyet más programok felhasználhatnak

${ }^{11} \mathrm{Az}$ alábbi országokban az alábbi közösségi hálózatok a legnépszerúbbek: Kínában a QZone; Oroszországban, Kazahsztánban, Belorussziában, Ukrajnában, Fehéroroszországban a VK (VKontakte); Iránban a Facenama; Japánban a Twitter (Vincenzo, 2016)
} 


\section{ANONIMITÁS, ADATVÉDELEM}

Elsőként a releváns irodalmat ismertetem, amelyek az anonimitás fogalmával, a jelenlegi személyes adatainkat védő szabályozással, valamint az anonimitás keresésének és elvesztésének következményeivel foglalkoznak.

\subsection{Az anonimitás definíciója}

Ahogyan a valós életben, az emberek online is sok esetben burkolózhatnak anonimitásba (Rigby, 1995). Ilyen esetek lehetnek például, ha egy online fórumon valamilyen kényes témáról beszélgetnek (betegségek, kisebbségi kérdések, szexuális élet stb.) és a beszélgetés alanyai nem szeretnék felfedni valódi kilétüket, mert attól tartanak, hogy a valós életben az online tett kijelentésük miatt megbélyegeznék őket.

Gary Marx (Marx, 1999) definíciója szerint az anonimitás azt jelenti, hogy az általa meghatározott 7 azonosítási dimenzió egyik tulajdonsága sem ismert az azonosítandó illetőről. Az azonosítás 7 dimenziója:

- név

- helyzet

- álnév, amely utal a személy nevére vagy helyzetére

- álnév vagy becenév, amely egyértelmúen nem utal a személy nevére vagy helyzetére, de a kérdéses személy nyomára vezethet

- viselkedési minták

- társadalmi réteghez való tartozás

- információ vagy tudás, amely jellemző a személyre

A listában található elemek egy része teljesen konkrétan beazonosítja az adott személyt, a másik része olyan tudásra utal, amely segítségével kikövetkeztethetô az egyén személyazonossága. Tehát az anonimitást kereső személyek elkerülik a fentebb említett 7 kategória valamelyikébe sorolható személyes adataikat felfedjék. A felsorolásban a viselkedési minta kulcsfontosságú, hiszen a kutatásaim során a látogatókat az online környezetben kinyilvánított viselkedésük és preferenciáik alapján azonosítom be.

Andreas Pfitzmann és Marti Hansen szerint az anonimitás egy olyan állapot, amelyben nem lehetséges egyértelmúen beazonosítani egy tett végrehajtóját. A 
potenciális elkövetők halmazát az anonimitás készletnek (anonymity set) nevezi, amelyek közül bármi egyenlő eséllyel lehet az elkövető. (Andreas \& Marit, 2010)

Bizonyos esetekben, például pénzügyi tranzakciók esetében az egyének szintén anonimitásba burkolózhatnak, de a későbbiekben felfedhetik a kilétüket. Az egyén kiléte felfedését követően már nincs további lehetősége újból anonimitásba burkolózni.

\subsection{A személyes adatok védelme (privacy)}

Amíg az anonimitás az elkövető személyének felfedhetetlenségével, a személyes adatok védelme (privacy) pedig a (bún)elkövető által elkövetett cselekmények elrejtésével foglalkozik. (Mano, 2011)

A személyes adatok védelmének (privacy) definícióinak egy része az ember szükségleteit állítja a központba, míg mások a jelen korban is aktuális személyes információ feletti kontrollt. A személyes adatok védelmét az emberi szükségletekre visszavezető meghatározások:

- Az egyének a személyes adatainak védelmére való törekvése egy nem akaratlagos emberi szükséglet, melynek célja, hogy bizonyos tevékenységeinket egyedül végezhessük el, az anonimitás pedig az a fogalom, amikor egy mindenki számára látható cselekedet vagy tevékenység eredményéből harmadik fél számára nem lehet kideríteni az elkövető személyét. (Falkvinge, 2013)

- Xu, Dinev és Smith pedig gazdasági szemszögből írja le a fogalmat. Szerinte a titoktartás alapvető emberi jog: a személy joga az egyedülléthez. Nem abszolút jog abban az értelemben, hogy a mindenkori gazdasági elvek és a költséghaszon közötti kompromisszum. (Xu, Dinev, \& Smith, 2011)

Az egyén saját maga személyes adatai felett gyakorolt kontrollt középpontba helyező definíciók:

- France Bélanger és Robert E. Crossler meghatározása szerint az információs magánélet/titoktartás (information privacy) az egyén befolyásolási vagy irányítási képessége a saját adatai felett. (France \& Robert, 2011)

- Charles Fries a fogalmat szintén az egyén a saját adatai feletti irányítási képességként definiálja, Alan Westin meghatározása szerint pedig az információs magánélet/titoktartás (information privacy) az egyének, csoportok 
és intézmények joga afelett, hogy milyen információt közöljenek mások számára. (Rössler, 2004)

- Roger Clarke szintén hasonló módon definiálja a kérdéses fogalmat: az egyéni érdek, hogy irányíthassa vagy legalább jelentős befolyással bírjon a személyes adatai kezelésére. (Clarke, 1999) Majd az alábbi 4 kategóriába sorolta az információs magánéletet/titoktartást: személyi, viselkedési, kommunikációs és személyes adattal kapcsolatos.

Manapság igen aktuális témának számít az informatikai adatvédelem, ahogy az információ technológia a hétköznapi életünk részévé válik, ezzel együtt a minket körülvevő elektronikus készülékek száma folyamatosan nő, amelyek folyamatosan gyűjtik rólunk az elérhető adatokat. Emiatt - európai értelmezés szerint - az állam egyik feladata, hogy az állampolgárai számára megfelelő arányban biztosítsa az az adatvédelmi jogokat, de ezzel párhuzamosan biztosítsa védelmüket a terrorizmus ellen vagy lássa el a közterületek védelmét vagy a járványok terjedésének megelőzését. Az egyén érdekei egymással ellentétesek lehetnek. (Rössler, 2004)

Ezek miatt Robyn L. Raschke és társai által írt „Understanding the Components of Information Privacy Threats for Location-Based Services” a GPS képes eszközök veszélyeivel foglalkozó cikkében kiemeli, hogy mára a nem informatikai cégeknek is egyértelmúen kell kommunikálniuk és jelezniük, hogy miként kezelik és védik az ügyfeleik személyes adatait. Ez az igény annyira nagy, hogy a Szövetségi Hírközlési Bizottság (Federal Communications Commission) kiadott egy legjobb gyakorlatokat összefoglaló riportot a személyes adatok védelmével kapcsolatban. A személyes adatokkal foglalkozó rendszereket már azok tervezési szakaszában fel kell készíteni a lehető legmagasabb fokú védelemre (Robyn, Krishen, \& Kachroo, 2014)

Helen Kennedy „Beyond anonymity, or future directions for internet identity research” címú cikkében az előző gondolattól jóval tovább megy, a cikkében azt állítja, hogy eljött az idő, hogy az internetes identitás fogalma elmozduljon az „internetes identitás anonim, többszörös és több darabból álló” ténytől az „internetes identitások összeegyeztethetőek az offline énünkkel” tényig. Tehát az online énünk gyakran egybevág az offline-nal, nem pedig bizonyos valós énre jellemző tulajdonságok átformált változatai. (Kennedy, 2006)

Az emberek hozzáállása a magánélet/titoktartás (privacy)-hoz ellentmondásos, mivel szeretnek mások életébe belepillantani, de a sajátjukat már nem szeretik 
közzétenni. Érdekes, hogy a közösségi hálózatok megjelenésével a felhasználók tömegének egy újszerú viselkedése jelent meg: akár az életük jelentéktelennek számító vagy akár intim pillanatait is közé lehet tenni. Teszik ezt sokan, a tettük súlyának felmérése nélkül. Ezt hívják magánélet/titoktartás (privacy) paradoxonnak. Az egyének féltik a magánéletüket (privacy), de sokszor ezzel ellentétesen cselekszenek. A magánélet/titoktartás (privacy) rizikó az a mérték, amely az egyént éri, ha a személyes adatai kompromittálódnak. (Xu, Dinev, \& Smith, 2011)

A további fejezetekben kifejtett kutatásaimban leírom, hogy milyen személyes információk elérhetőek a weboldalak számára az internetes böngészés során. A közösségi hálózatok és kiterjedt hálózattal rendelkező weboldalak sok személyes adatot nyerhetnek ki az egyének online viselkedéséből, amelyeket ók nem feltétlenül explicit módon fedtek fel magukról.

Manapság az egyén személyes adata igen fontos jószággá vált, nincs megbízható kontrollunk afelett, hogy a megosztott vagy közzétett személyes adatok garantáltan eltüntethetőek vagy visszavonhatóak.

\subsection{Törvényi szabályozás}

Az egyes társadalmak az adatvédelem kérdéséhez különféleképpen viszonyulnak: az Európai Unió direktívái jóval szigorúbbak az Egyesült Államok hasonló tárgyú törvényeinél. Az USA jogszabályozása megengedi az akár már anonimizált számítógépes adatok újbóli személyekhez kötését, az összegyújtött személyes adatok harmadik fél számára történő átadását vagy az egyénre jellemző böngészőhasználat jellemzőinek gyújtését. (Rössler, 2004) A különbség abból eredeztethető, hogy a nyugati és az európai társadalmak különféleképpen értelmezik a magánéletet és a szabad akaratot, amelyet legkönnyebben a joggyakorlatokat vizsgálva érthetjük meg:

- Az Amerikai Egyesült Államok törvényei a fó hangsúlyt arra helyezi, hogy az állam az állampolgárokat „békén hagyja”. Itt legfontosabb az egyén szabad akarata.

- Németországban a fó hangsúly azon van, hogy az állam figyelheti-e, amit a polgárai csinálnak vagy mondanak és ha igen, akkor azt milyen szinten. Emiatt a privát szféra védelme akkor merül fel, amikor az emberek a mindennapi életük során már fenyegetve érzik magukat. (Rössler, 2004) 
Az uniós joggyakorlat szerint személyes adatok szigorú feltételek mellett gyűjthetőek, kizárólag célhoz kötötten, az adattulajdonos hozzájárulásával.

2016. május 4-én hirdették ki az EU 2018. május 25-én hatályba lépő 2016/679/EU Általános Adatvédelmi Rendeletét (General Data Protection Regulation - GDPR), amely az alábbiakról rendelkezik:

- a személyes adatok törléséhez való jog

- az adathordozáshoz való jog

- az adatvédelmi incidensről való értesülés joga

- a közérthető adatvédelmi magyarázathoz való jog. (Halász, 2016)

A rendelet a 1995-ben hatályba lépett 95/46/EK korszerúsített változata, (Személyes adatok feldolgozása vonatkozásában az egyének védelméről és az ilyen adatok szabad áramlásáról, 1995) és a technológiai fejlődés következtében kialakult új helyzet szabályozására szolgál. (Halász, 2014) Az új szabályozás az Európai Unió tagállamaiban alkalmazott egymástól eltérő adatvédelmi szabályokat igyekszik egységesíteni, ami által teszi lehetővé a szabályozott nemzetközi adatcserét. A szolgáltatókra szigorú előírások vonatkoznak, amelyeket azok kötelesek betartani. A személyes adatokat gyújtő és kezelő személyek vagy szervezetek kötelesek azokat megvédeni a visszaéléstől. A nem megfelelően eljáró szervezeteket a jövőben keményen szankcionálják. (Európai Bizottság, 2015)

\subsection{Az anonimitás keresésének okai}

Az online világot használók számára az anonimitás biztosítja, hogy az identitásuk harmadik fél számára ne legyen felfedhető. Az online anonimitásnak különböző szintjei léteznek a névtelen fórumhasználattól a biztonságos fizetésig. Amíg az előbbi esetben a cselekvés eredményét mindenki láthatja, csak a cselekvő személye nem felfedhetô, azaz pszeudonimitásról beszélünk, addig a második esetben harmadik fél számára a teljes tranzakció megtörténte titokban kell, hogy maradjon. (Andrews, Gilbert, Repper, Roth, \& Wear, 2011)

$\mathrm{Az}$ emberiség történelme tele van olyan történetekkel, amelyben szerepet játszott az anonimitás. Rick Falvinge „How Does Privacy Differ From Anonymity, And Why Are Both Important?” címú cikkében példaként említi az Amerikai Egyesült Államok kialakulását is. Az egykori angol gyarmat - a jelenlegi Amerikai Egyesült Államok - területén dokumentumokat és röpiratokat tűztek ki a fákra, amelyeken 
keresztül buzdították a lakosságot Angliától való elszakadásra. Abban az időben ezért a tettért halálbüntetés járt. Így nem volt kérdés, hogy a tettet végrehajtók miért maradtak anonimak. Így tehát nem létezne az Amerikai Egyesült Államok, ha nem létezett volna anonimitás a Függetlenségi Nyilatkozat aláírása előtt. A magánélet/titoktartás (privacy) és az anonimitás is szükséges a demokratikus közösségben. (Falkvinge, 2013)

Az anonimitás fogalomköréhez szorosan kötődik a pszeudonimitás azaz álnév használata. Érdekes gondolat, hogy tulajdonképpen a világon senki sem anonim, inkább pszeudonim. (Andreas \& Marit, 2010)

Az előbb említett példán kívül is több oka lehet, hogy az emberek miért nem akarják felfedni kilétüket. Ruogu Kang, Stephanie Brown és Sara Kiesler "Why do people seek anonymity on the Internet? Informing Policy and Design" cikkében az anonimitás használata az Internet használatából eredeztethető az alábbiak szerint (Kang, Brown, \& Kiesler, 2013):

- közérdekü bejelentők: a nyilvánosságot nem vállaló, de szabálytalanságot elsőként bejelentők

- megbélyegzett csoportok tagjai: kisebbségiek, betegek stb.

- érzékeny/kényes tartalmakat keresók: betegséggel, nemi hovatartozással vagy egyéb érzékeny témával kapcsolatos témájú tartalmakat keresők

- hackerek: számítástechnikai szakember, aki képes egy számítástechnikai rendszerből lehetetlennek hitt funkciókat előhozni

- besúgók/kémek: olyan emberek, akik mások számára információkat szolgáltatnak egy személyről

Tehát aszerint, hogy mi a célja az egyes személyeknek az online világban, változik az anonimitás keresésének módja is.

Azonban feltehetjük úgy is a kérdést, hogy miért osztják meg a felhasználók a közösségi hálózaton a személyes adataikat? Mi érdeke fűződik a közösségi hálózatoknak ahhoz, hogy a felhasználóik ezt az ő oldalukon tegyék? Talán a második kérdésre egyszerúbb megadni a választ: Racskó Péter (Szommer, Balogh, \& Racskó, 2014) szerint az emberek százmilliói használják az „ingyenes” közösségi hálózatokat, amiért lényegében a személyes adataikkal fizetnek. A közösségi oldalakon található felhasználókat a megadott személyes adataik alapján könnyen lehet profilozni és célzott reklámokat küldeni nekik. A reklámokból befolyt jövedelemből tartják fenn 
magukat a közösségi oldalak. A magánélet (privacy) alapvető emberi jog (Smith, Dinev, \& Xu, 2011), amiről a felhasználók dönthetnek, hogy milyen mértékben kívánnak élni. Az Internet és a széles körben használt közösségi oldalak miatt felmerülhet a kérdés a magánélet újraértékeléséről és újraértelmezéséről. Az személyes adatok védelme terén az internet fejlődéséhez képest a világ jelentősen le van maradva.

A New York Times - Customer Insight Group kutatócsoportja készített egy felmérést 2011-ben arról, hogy a felhasználók adatmegosztásának okairól. Maga az információ megosztása korántsem újszerû dolog, a 2500 fôs kutatás eredményéből kiderül, a közösségi hálózatok megjelenésével az információ megosztására való igény felgyorsult. (Brett, 2011)

A felhasználók információ megosztási kedvének több oka is lehet, az internetet böngésző személy személyiségétől függően változhat az információ megosztásának oka. A kutatás 6 különböző csoportba sorolják az internetezóket az alábbiak szerint:

- Az önzetlenek segítőkészek, megbízhatóak és figyelmesek. Többségük email-ben kommunikál és az információt csatolmányként vagy linkként küldik tovább.

- A karrieristák intelligens internethasználók, ők azok a közösségi hálózatokban rejlő potenciált elsőként felfedezték. Jellemzően a LinkedIn-t vagy a Facebook-ot használják a kapcsolataik építésére.

- A hipszterek fiatalok, népszerúek és szeretik a legújabb technológiát. Ők nem az e-mail-t részesítik előnyben, hanem a kommunikáció gyorsabb és korszerúbb fajtáit, mint az SMS, Twitter vagy a Skype.

- A bumerángok azért osztanak meg tartalmakat, hogy visszaigazolást nyerjenek, vagy valamilyen reakciót váltsanak ki. Főként a közösségi hálókat használják, mint a Twitter és a Facebook.

- A csatlakozók csoport tagjai kreatívak, figyelmesek és nyugodtak. Ők nagy valószínúséggel e-mail-t vagy Facebook-ot használnak, szeretik az ingyenes termékeket és a promóciókat.

- A válogatósok csoport tagjai leleményesek, gondolkodók és óvatosak a megosztott információval kapcsolatosan. E-mail vagy privát üzenet küldését részesítik előnyben a közösségi hálózatokhoz képest. Ezek a felhasználók 
tudatában vannak annak, hogy az Internetnek memóriája van, még akkor is, ha azt utólag letöröljük.

\subsection{Az anonimitás elhagyásának következményei}

Az anonimitás témakörének tárgyalása során említést kell tennünk az anonimitás felfedésének következményeirôl. Az internetezéshez használt eszközök, a szoftverkörnyezetük és a látogató online viselkedésének jellemzőinek egy jelentős része hozzáférhető a meglátogatott weboldalak számára. Az összegyújtött adatból sok hasznos információt lehet kinyerni adatbányászati módszerekkel. Az így kinyert információkból az oldal szolgáltatásait lehetséges fejleszteni vagy a látogatók számára célzott reklámok küldhetőek a webhely által kínált szolgáltatás használata közben.

A kinyert információk segítségével akár teljesen egyénre szabott felületet kaphatnak a személyes preferenciáik által kategorizált látogatók. Azonban a felhasználók elérhető jellemzőik alapján történő kategorizálásának okozata nem feltétlenül pozitív, mint ahogy arra Eli Pariser is felhívta a figyelmet a Beware online „Filter Bubbles” címú előadásában, ugyanis nem a vizsgált alany dönti el, hogy a tartalmat milyen megközelítésből szeretné megtekinteni és abba sincs beleszólása, hogy mi az a tartalom, amelyet nem fogyaszthat. Állítása szerint a különböző felhasználói csoportok különböző keresési eredményoldalakat láthatnak a földrajzi elhelyezkedésüknek megfelelően. (Pariser, 2011)

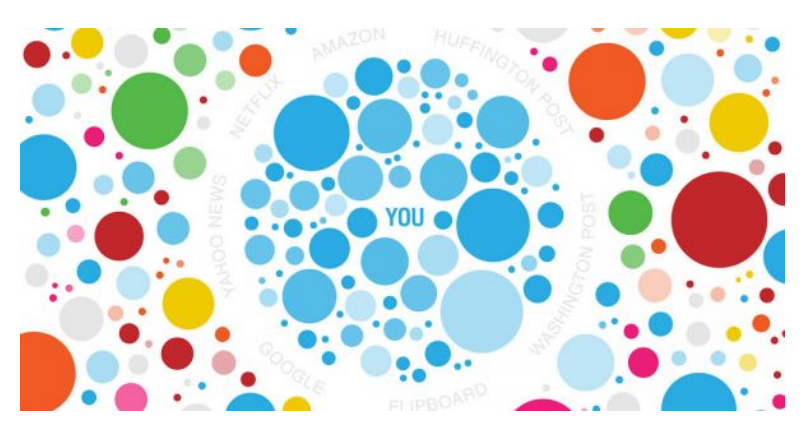

1. ábra: Filter bubble grafikus ábrázolása (Pariser, 2011)

Az információs technológiák fejlődésének következményeként az online világban a valós életünk egyre több aspektusa és a személyiségünk egyre több jellemzője válik hozzáférhetővé. A közösségi hálózatok térhódításával a felhasználók önként osztanak meg magukról tartalmakat, amely elősegítheti a róluk készített profilok pontosabbá tételét. Ezt a jelenséget az angolszász irodalom ,privacy 
paradox"-nak nevezi: a látogatók elvárják, hogy az adataik védve legyenek az illetéktelenek elől, azonban ezzel ellentétesen viselkednek és felelőtlenül tesznek közzé tartalmakat vagy a személyes adataikat elérhetővé teszik azt kérelmező harmadik felek számára. 


\section{A LÁTOGATÓK AZONOSÍTÁSÁNAK ÉS KÖVETÉSÉNEK MÓDSZEREI}

A látogatók azonosításához és követéséhez a webes böngészés átfogó ismerete szükséges. A fejezet elején leírom a téma megértéséhez szükséges webes böngészés folyamatát. Ezt követôen a kutatásaimhoz szükséges saját fejlesztésú adatgyűjtő alkalmazás lefejlesztése előtt összegyűjtöttem a látogató eszközéről, operációs rendszeréről, annak szoftverkörnyezetéről, valamint magáról a látogatóról rendelkezésre álló adatok legszélesebb körét. Ezt követően az előző lépésben összegyújtött adatok gyújtésének lehetőségeit vizsgáltam. Majd a 3.4.3 Látogató azonosítása és követése alfejezetben az összegyújtött adatokból kiindulva a látogatók azonosításának és követésének lehetséges módszerét írom le.

\subsection{A kliensoldal}

A weboldalak látogatói a kliensoldalon, a böngészőt használva az internetezésre alkalmas eszközükön tekintik meg a weboldalakat.

\subsubsection{Böngészök}

A webes tartalmak fogyasztására különböző hardvereket használhatnak, melyek tulajdonságaikban jelentősen eltérhetnek egymástól. A világhálón található weblapokat emiatt szokták különféle eszközcsoportokra optimalizálni. A gyakorlatban lehetetlenség lenne minden eszközre külön optimalizálni az weblapokat, ezért megjelenítés előtt az „okos” weblapok és webes alkalmazások lekérdezik a képernyője szélességét, majd annak megfelelő tartalmat jelenítenek meg. Ezeket a szaknyelv responsive design-nak nevezi.

Régebben a különböző böngészők számára a tartalmat a szerveren generálták le, az interneten található weboldalak mobil eszközökre optimalizált verzióját általában az ' $m$ ' aldomain alatt érhető el, de néhány esetben külön domain alá helyezik át. Manapság a böngésző szélességének függvényében jeleníti meg a böngésző az optimális tartalmat. (Twitter Bootstrap, 2014)

A böngészők, mint alkalmazások az internetről letöltött HTML (lásd 8.1 HTML fejezet) oldalakat képesek megjeleníteni. Széles körben elterjedt, weboldalakba ágyazható kliens oldali programozási nyelv a Javascript (lásd 8.3 
Javascript fejezet). Az oldalak letöltésének folyamatát részletesen a 8.2 HTTP lekérdezés fejezetben tárgyalom.

Egy felhasználó több eszközt használhat internetezésre. Sőt az sem ritka, hogy egy eszközön több különböző böngészőt használjon valaki. Ez azért fontos tény, mert egy eszközre telepített böngészők nem képesek olvasni egymás kliens-oldalon tárolt adatait (sütiket, localStorage stb.), így ez a felhasználó követését megnehezíti. A látogatók teljes böngészési szokásainak felderítésének fontos része, hogy a felhasználó által használt összes eszközböngésző felderítése és felhasználóhoz való kapcsolása.

A kliens hardverére telepített internetes tartalmak megjelenítésére alkalmas szoftver a user-agent, ez leggyakrabban a böngésző. HTML nyelvú dokumentumokat képesek értelmezni és megjeleníteni. Több ezer féle böngésző létezik, azonban a felhasználói körük erôsen koncentrált. Az internetes társadalom túlnyomó többsége az 5-6 legismertebb böngészőt használja. Az alábbi táblázatban tekinthető meg az 5 legismertebb böngésző elterjedtségte 2017. februárjában.

\begin{tabular}{|l|c|c|c|c|c|}
\hline & $\begin{array}{c}\text { Microsoft } \\
\text { Internet } \\
\text { Explorer/Edge }\end{array}$ & $\begin{array}{c}\text { Mozilla } \\
\text { Firefox }\end{array}$ & $\begin{array}{c}\text { Google } \\
\text { Chrome }\end{array}$ & $\begin{array}{c}\text { Apple } \\
\text { Safari }\end{array}$ & Opera \\
\hline $\begin{array}{l}\text { 2017. } \\
\text { február }\end{array}$ & $4,8 \%$ & $15,0 \%$ & $74,1 \%$ & $3,6 \%$ & $1,0 \%$ \\
\hline
\end{tabular}

2. táblázat: 5 legelterjedtebb böngészóo (W3Schools, 2017)

A különböző böngészők különböző megjelenítő motorokkal rendelkeznek, amelyek eltérő módon jelenítik meg a weblapokat és különbözőképpen hajtják végre a Javascript utasításokat. 


\begin{tabular}{|l|c|}
\hline \multicolumn{1}{|c|}{ Böngésző } & $\begin{array}{c}\text { Megjelenítő motor } \\
\text { (layout engine) neve }\end{array}$ \\
\hline Microsoft Edge & EdgeHTML \\
\hline Microsoft Internet Explorer & Trident \\
\hline Mozilla Firefox & Gecko \\
\hline Google Chrome & Blink \\
\hline Apple Safari & WebKit \\
\hline Opera & Presto \\
\hline
\end{tabular}

3. táblázat: Néhány ismertebb böngészó és megjelenitố motorja (Stanclift, 2008)

\section{Az inkognitó mód}

A böngészők többségében a 2008-2010 között jelent meg az inkognitó mód ${ }^{\mathbf{1 2}}$. Normál használat közben a böngészők többek között az alábbi adatokat mentik merevlemezre:

- meglátogatott weblapok tartalma (cache)

- meglátogatott weblapok időpontja

- cookie-k, localStorage és sessionStorage tartalma

A felhasználó által meglátogatott weblapok tartalmát a böngésző a merevlemezre menti, mert a weboldal későbbi meglátogatása esetén csak a módosult elemeket kell letölteni, ezáltal tehermentesíthető a hálózat, valamint a weboldal megjelenítése is sokkal gyorsabb lesz. A böngésző normál üzemmódját használva a böngészés befejeztével a merevlemezre lementett adatokból visszanyerhető a felhasználó böngészési előzménye. Ezt elkerülhető az inkognitó mód használatával, mert ebben az esetben a böngésző a munkamenet befejeztével nem hagy nyomot a merevlemezen, tehát olyan, mintha a böngészés meg sem történt volna. A böngésző bezárásával a sütik törlődnek a localStorage pedig a sessionStorage-hoz hasonló viselkedést mutat és az is szintén törlődik a munkamenet lejártával. Fontos megjegyezni, hogy az inkognitó mód használatával a weboldalak ugyanúgy követhetnek minket, számukra minden adat és azonosítási faktor ugyanúgy elérhetô, a bejelentkezés nélküli böngészés esetében is.

\section{HTTP fejléc}

\footnotetext{
${ }^{12}$ böngészőnként máshogy hívják: Internet Explorer-ben InPrivate mode, Mozilla Firefox-ban Private browsing, Google Chrome-ban incognito mode stb.
} 
A böngészők a HTTP lekérdezések fejlécében az 2. ábra látható elemeket küldik el, melyek közül az egyes elemek jelentése rendre:

- Accept: a böngésző által kezelni képes állományok és prioritásuk

- Accept-encoding: a böngésző által támogatott átvitel során használható tömörítési algoritmusok

- Accept-Language: a böngésző által támogatott nyelvek

- DNT (Do-no-track): ha a mezó értéke 1, akkor a meglátogatott weblap nem fogja követni a felhasználót

- Host: a lekérdezni kívánt URL

- User-Agent: a weboldal megjelenítéséhez használt eszköz, a böngésző és operációs rendszer típusának és verziójának megállapítására szolgáló szöveg, jelen esetben az operációs rendszer típusa Windows 7, 64 bites verzió, a böngésző pedig Mozilla Firefox 22 (Gecko), a hardverről nem tartalmaz semmi extra adatot

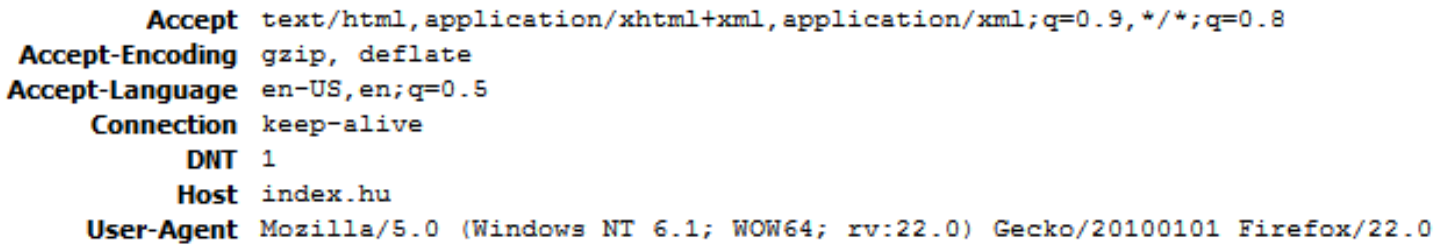

2. ábra, az index.hu HTTP lekérdezés fejléce (saját felvétel)

A User-Agent string felépítése a következő:

Mozilla/x.o (operációs rendszer jellemzői) megjelenítő motor

(böngésző jellemzői) telepített szolgáltatások

Az alábbi jellemzőket foglalja magában:

- Mozilla megjelenítő motorral való kompatibilitás

- A böngészőt futtató operációs rendszer jellemzői

- A böngésző megjelenítő motorjának neve és verziója

- Böngésző neve és verziója

- Telepített szolgáltatások és egyéb jellemzők (Andersen, 2008) (Shall, 2017)

\section{DNT}

A 2. ábrán is látható, hogy a böngésző elküldött egy DNT paramétert a HTTP fejlécben. Ez a Do-Not-Track kifejezés rövidítése, ami magyarul annyit jelent: "ne 
kövess" (Mozilla.org). Bevezetését a W3C $C^{13}$ 2009-ben indítványozta. Ha látogató úgy kívánja, hogy az általa meglátogatott weblap vagy egyéb harmadik fél ne kövesse őt, a böngésző a HTTP lekérés fejlécében elküldi ezt az információ a szervernek. Mára az ismertebb böngészők támogatják a DNT fejléc küldését, azonban a felhasználók nagy része nem tud róla, mivel nem reklámozzák ennek lehetőségét a böngészők. 2012 decemberében a Firefox felhasználók 90\%-a nem használta még ezt a funkciót. (Mathews, 2013) A kapcsoló hatását a felhasználó nem tudja ellenőrizni, hiszen nem kap semmiféle visszajelzést, hogy az általa meglátogatott weblap bármit is lementett róla. A Yahoo! és a Twitter támogatja ezt a funkciót. Azonban a felhasználó semmilyen visszajelzést nem kap arra vonatkozóan, hogy a weblap támogatja-e ezt a funkciót, valamint, hogy azt valóban be is tartja-e.

A DNT jövője megkérdőjelezhetô, mivel a valódi célját nem éri el a felhasználó a használatával, hanem pont az ellenkezőjét, ugyanis a HTTP fejlécben átküldött DNT is hozzájárulhat egy eszközböngésző beazonosításához. A Yahoo! elsőként kezdte el támogatni a DNT-t, azonban 2014. májusában a Yahoo! felfüggesztette azt. (The Stanford Review, 2014)

\subsubsection{A munkamenet}

A HTTP szerver nem jegyzi meg a kliens adatait az egyes lekérdezések kiszolgálása között. Ezt a rést hivatott kitölteni a munkamenet. A kliens minden HTTP lekérdezés fejlécében elküldi az adott domain-hez tartozó érvényes munkamenet sütiket. Első látogatás alkalmával, amikor a szerveroldalon indítjuk a munkamenetet a szerver generál egy 27-40 karakter hosszúságú betűkből és számokból álló munkamenet azonosítót, amelyet visszaküld a kliens számára. Ez lesz a munkamenet azonosítója, amelyet a PHP alapesetben PHPSESSID nevú sütiben tárol. A süti egy kliens oldali adattároló technológia, bővebb leírása a Süti (cookie) fejezetben olvasható.

A szerveroldalon egy kitüntetett könyvtárban létrehoz egy file-t az előzőleg kiosztott munkamenet azonosító néven, a tartalma pedig a munkamenetbe elmentett változók és azok tartalma lesz. Lehetőség van akár tömbök és objektumok tárolására is, ebben az esetben szerializálva ${ }^{14}$ lesznek elmentve. A következő oldalletöltés

\footnotetext{
${ }^{13}$ World Wide Web Consortium: nemzetközi internetes szabványügyi konzorcium

${ }^{14}$ Memóriabeli objektumok szöveges formában történő ábrázolása
} 
alkalmával a munkamenet azonosítónak megfelelő munkamenet file tartalma rendelkezésre fog állni a programozási környezetben.

A kliensoldalon a munkamenet azonosító egy sütiben tárolódik. Amikor a látogató ismételten meglátogatja az oldalt, amelyhez a süti tartozik, a böngészó a lekérdezés fejlécében elküldi azt a szerver számára.

Ha egy támadó megszerzi egy bejelentkezett felhasználó munkamenet azonosítóját és bemásolja a saját gépén a weboldal által készített süti file-ba, akkor hozzáférhet az áldozata által látott tartalmakhoz. Ez természetesen csak abban az esetben múködik, ha a weboldalt nem készítették fel a session fixation támadás ellen. A védekezés egyszerú, csak ellenőrizni kell minden lekérdezésnél a látogató IP címét és User-agent stringjét. Ha valamelyik eltér az előző lekérdezésben meg, a felhasználót ki kell léptetni.

Mi történik olyan esetben, ha a kliens letiltja a sütiket? Ha a weblap megírója nem végzett alapos munkát, akkor a felhasználók nem fognak tudni bejelentkezni, mivel a lekérdezések fejlécében nem lesz benne a munkamenet azonosítója.

\section{Google accounts}

Your browser's cookie functionality is turned off. Please turn it on. [?]

\section{3. ábra, A GMail nem müködik sütik használata nélkül (saját szerkesztés)}

Az olyan weboldalak, amelyek esetében követelmény, hogy sütiket nem támogató böngészókben is futtathatóak legyenek, (pl: banki rendszerek) a query string használható a munkamenet azonosító átküldésére.

\subsubsection{A kliens oldali adattárolás}

A HTML5 egyik nagy újítása a kliens-oldali adattárolási lehetôségek kibővítése. Több fontos különbség is van - az elődje - a sütik és az Web Storage technológiák között, hogy az utóbbiak mérete a sütik méretének sokszorosa (5-25 MB a böngésző fajtától függően) is lehet, valamint a tárolt adatok a lekérdezések során nem lesznek elküldve a szervernek.

A localStorage és sessionStorage a sütikhez hasonlóan kulcs-érték párok tárolására szolgáló technológia kliensoldali technológia. Amíg sessionStorage csak a munkamenet idejére jegyzi meg a beleírt adatokat, a localStorage-ban tárolt adatok a 
böngésző bezárása után is használhatóak maradnak. A localStorage előnye, hogy egyelőre kevés olyan alkalmazás ismeri, amellyel a felhasználók a böngészési gyorsítótárat törölheti le, így az abban tárolt adatok hosszabb idôn át maradnak elérhetőek. Mára széles körben elterjedt technológia. ${ }^{15}$

Egy másik adattárolásra alkalmas technológia a WebSQL, ami a böngészőbe implementált SQL adatbáziskezelő. Jelenleg a Chrome, Opera, Safari és kiegészítővel a Firefox is támogatja, az IE nem. ${ }^{16}$

Az application cache szintén a HTML5 egyik újdonsága, amely arra hivatott, hogy a weblapok offline állapotban is nyújthassanak funkcionalitást. Amíg a webes alkalmazás online állapotban van, letölti az offline múködéshez szükséges részeket. ${ }^{17}$

A SharedObject, Flash sütinek is hívott kliens oldalon tárolt adatcsomag. Működése nagyon hasonló a normál sütiéhez, azonban ezt csak Flash alkalmazásokból lehet elérni, viszont mérete nem csak 4 kB lehet, hanem alapból 100 kB. Ha a kliens gépén futó alkalmazásnak ennél is több helyre van szüksége, akkor az alkalmazás először kérvényezi a tárterület megnövelését a felhasználótól, aki saját belátása szerint engedélyezheti vagy elutasíthatja azt. A SharedObject nagy előnye, hogy azt egyszerre több Flash alkalmazás is tudja használni és annak változása esetén értesítést kapnak róla.

Etag vagy Entity Tag a HTTP protokoll része. Tulajdonképpen egy mechanizmus, amely segítségével a böngésző megállapíthatja, hogy az ismételten letölteni kívánt tartalom frissült-e a szerveren. Ha a böngésző gyorsítótárában található file nem frissült a szerveren, akkor felesleges azt újra letölteni, így ezzel értékes idő és sávszélesség takarítható meg. Egy file gyorsítótárazása során a böngésző elmenti a file módosításának dátumát. Így annak a kiderítése, hogy a file frissült-e a szerveren az, ha összehasonlítjuk a szerveren lévő file módosításának dátumát a letöltött file módosításának dátumával. Ha a szerveren lévő korábbi dátum, akkor le kell tölteni, mert a tartalma módosult. Az ETag-et a különféle webszerver alkalmazások különféleképpen számíthatják. Általában ez egy hash, amelyet a letölteni kívánt file tartalmából számítanak. Így, ha a letölteni kívánt tartalom utolsó módosításának dátuma nem frissülne, ez a hash akkor is változik.

\footnotetext{
${ }^{15} \mathrm{http} / / /$ caniuse.com/\#search=localstorage

${ }^{16} \mathrm{http}: / /$ caniuse.com/\#search=websql

${ }^{17} \mathrm{http}: / /$ caniuse.com/\#search=offline
} 
Az előbbiekben ismertetett kliens oldali adattároló technikák használatával a weboldalak képesek egy adott eszközt azonosítani, így alkalmasak a látogatók követésére. A több oldalba beillesztett komponensek révén az adatgyűjtő weboldal képes egy adott eszköz által meglátogatott weboldalak listájának előállítására.

A szakirodalom browser fingerprint néven szokott hivatkozni a böngészőből kiolvasott bizonyos paraméterekből képzett hash-re. Az Electronic Frontier Foundation (http://panopticlick.eff.org) oldalán az alábbi adatokból számítják a hasht, ami a felhasználó által használt eszközböngészőből lekérdezhető jellemzőkből alkotott adatcsoport, amely rövid időtávon eszközböngésző és a használójának azonosítására használható:

- user-agent string (HTTP_USER_AGENT)

- böngésző által kezelni képes állományok és prioritásuk (HTTP_ACCEPT)

- böngészőre telepített kiegészítők és verziójuk

- időzóna

- képernyő mérete és színmélység

- telepített betûkészletek

- sütik engedélyezve vannak-e?

- localStorage/sessionStorage és IE.userdata teszt (IE userdata a Microsoft által fejlesztett a localStorage-hez hasonló kliensoldali adattárolási technológia, IE5-tôl IE8-ig támogatott)

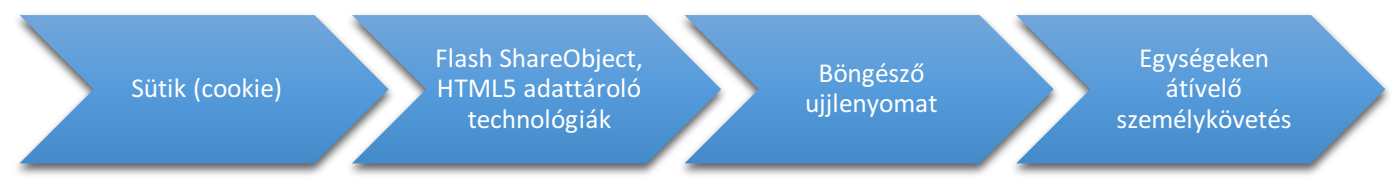

4. ábra, követésre alkalmas technológiák fejlódése (saját)

\subsection{A szerveroldal}

Az 5. ábra látható módon a böngésző a webszerverrel kommunikál, az pedig a lekért erőforráshoz rendelt programozási nyelvet hívja meg, hogy állítsa elő a kívánt tartalmat. A programozási nyelv - jelen esetben PHP - szükség esetén az adatbázishoz fordul az adatokért, majd a programkódban leírt módon feldolgozva azt előállítja a HTML kimenetet, amelyet a webszerver visszaküld a kliens számára. 


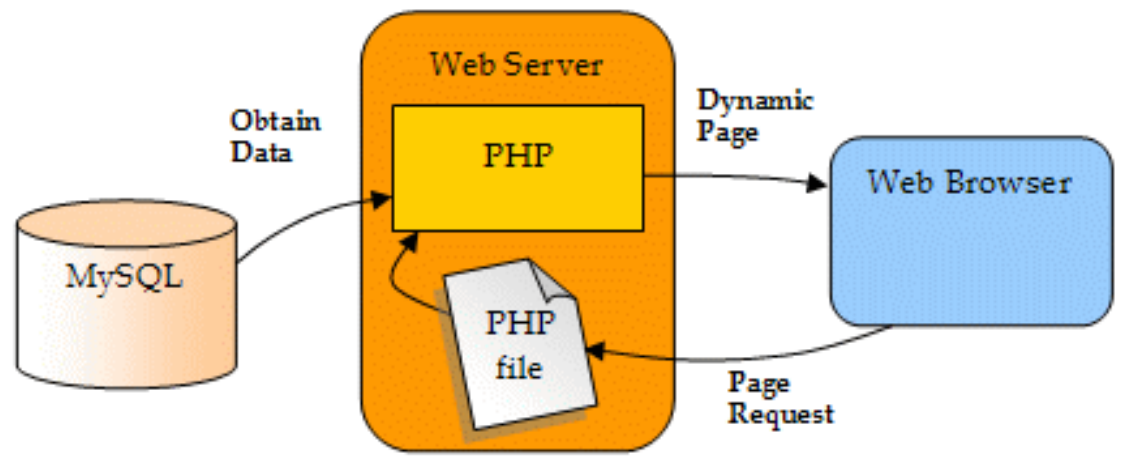

5. ábra: webszerver kapcsolata az adatbázissal és a böngészôvel (Bhavin, 2014)

Az internetes kommunikációs szabályokat a HTTP - Hypertext Transfer Protocol - foglalja magában, ami az ISO/OSI és a TCP/IP alkalmazási rétegének webes kommunikáció átvitelére alkalmas alprotokollja. A protokoll kérdés-válasz alapon múködik, ami azt jelenti, hogy általában a kliens küld egy kérést a szervernek, ami előállítja számára a választ és visszaküldi. A HTTP egy állapot nélküli protokoll, így az egy felhasználótól érkező lekérdezésekről a szerver alapesetben nem tárol információt vagy állapotot. Szükség esetén ez mégis lehetséges sütikkel, rejtett űrlap változók használatával vagy a query string-en keresztül.

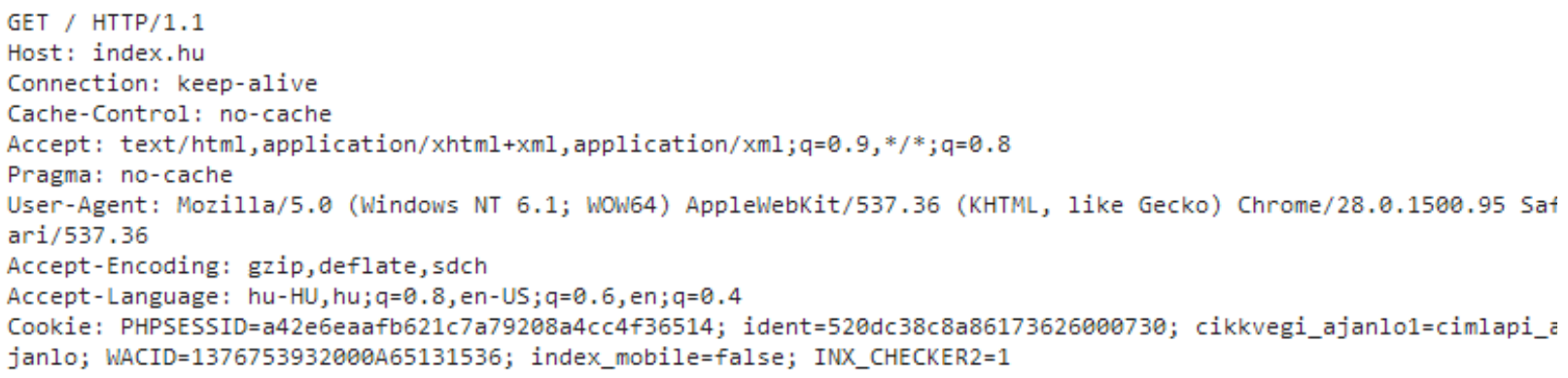

6. ábra, HTTP lekérdezés fejléce (saját felvétel)

A 6. ábra egy HTTP lekérdezés fejléce látható. Első sorában a lekérdezés metódusa látható, jelen esetben a GET metódust használja és a HTTP 1.1-es protokoll szerint zajlik a kommunikáció. A következő sorban látható a host, ahol elérhető a letöltendő adat. Majd több más paraméter közt az Accept a támogatott formátumokat, a User-Agent-et, a támogatott nyelveket és a sütiket jelöli.

A TOR (The Onion Router) egy anonimitást biztosító rendszer, amely böngésző és a webszerver közti kapcsolatot titkosítva biztosítja a küldő anonimitását. 
A rendszer a több szinten különböző titkosítással látja el a küldő csomagjait, megakadályozva a küldő pozíciójának kiderítését. (The Onion Router, 2015) Helyes használatával a weboldalak nem képesek a visszakövetni a látogatóikat, kivéve, ha megadják személyes adataikat.

\subsection{A böngészés folyamata}

A jelen dokumentumban felhasználó azonosításnak nevezem azt a folyamatot, amikor a felhasználó által használt eszközböngészők és a felhasználó viselkedéséből kikövetkeztetve ismertté válik valamilyen egyedi azonosítója (a felhasználó személye, rendszer azonosító (Facebook ID), e-mail cím stb.) vagy az üzlet szempontjából fontos tulajdonságai alapján profilozhatóvá válik.

Felhasználó követésnek nevezem azt a folyamatot, amikor két weboldal letöltésrôl egyértelmúen megállapítható, hogy ugyanaz a felhasználó indította a lekérdezést. Ebbe beletartozik az eszközböngészők egymáshoz kapcsolása is.

Az egy weblapon történő böngészésnek két fontos momentuma van:

- a weblap első megtekintése elsô alkalommal

- a weblap megtekintése a második vagy sokadik alkalommal

\subsubsection{A weblap megtekintése}

Egy weblap első és sokadik alkalommal történő megtekintése között az a különbség, hogy első alkalommal még nincs elindítva a munkamenet, így a lekérdezés fejlécében nem lesznek a munkamenet azonosítók elküldve a szervernek, így az egy felhasználótól független kimenetet fog visszaadni. Az első válaszüzenetben a szerver küldi vissza a kliens számára a munkamenet azonosítót, amelyet a böngésző elment.

A második vagy a sokadik alkalommal történő megtekintés során a lekérés fejlécében a böngésző elküldi a szerver számára az oldalhoz tartozó még nem lejárt sütiket, ami a szerveroldalon a kérés megérkezését követően a meghívott programozási nyelvben rendelkezésre fog állni, amennyiben munkamenet azonosító volt, akkor a munkamenet változók állnak rendelkezésre.

\subsubsection{A böngészés révén kinyerhetö adatok}

A látogatók beazonosításának és követésének legkézenfekvőbb módja, ha ezeket az adatokat maga a látogató bocsájtja az azt igénylő weblap számára. Ha elvetjük azt az esetet, amikor a látogató a regisztrációt követően mások számára is 
elérhetővé teszi a belépéshez szükséges azonosítóját és kódját, akkor a weblap minden esetben követni tudja őt, valamint elérhető lesz számára a látogató néhány adatát: időpont, IP cím, IP címből visszafejtett földrajzi pozíció, a webhely megtekintett weblapjai, HTTP fejlécből kinyerhető adatok és a DOM-ból kinyerhető adatok.

A regisztráció folyamán megadott adatok valódiságát természetesen nem lehetséges ellenőrizni. Ha nem ellenőrzi a webhely, akkor a látogatók hajlamosak hamis e-mail címek megadására. Emiatt szoktak sok esetben egy visszaigazoló e-mailt kiküldeni a megadott e-mail címre.

A felhasználó eszköze és a weblap szervere között történő kommunikációban az alábbi aktorok lehetnek érintettek:

- munkáltató/ISP (Internetszolgáltató): segítségével kapcsolódunk a világhálóra. Ez a szervezet adatokat szerezhet a hozzá csatlakozó felhasználókról.

- weblapok: a böngészés során megtekintett weblap információkat szerezhet a felhasználóról

- hirdetók és közösségi hálózatok: a weboldalakba helyezett nyomkövető kód révén információkhoz juthat a weblap látogatóiról.

- hackerek és kiberbúnözők: különféle módszerekkel adatokat szerezhetnek a weblapok látogatóiról

- állam: Az állam és az állami hatáskörbe tartozó szervezetek adatszolgáltatásra kötelezhetik a szolgáltatókat

- köztes csomópontok: a kommunikáció kezdő és végpontja közötti bármely csomópont, amelyen keresztülhaladnak az adott kommunikációhoz tartozó csomagok

A listából kitúnik, hogy bizonyos szereplők többletinformációkhoz is hozzáférhetnek az adott látogatóról. A kutatásom során csak a bárki által hozzáférhetô adatokra fókuszáltam, tehát a felsorolt aktorok közül többnyire a weblapok, kisebb részt a hirdetôk és a közösségi hálózatok a kutatásom alanyai. Ezek az aktorok ugyanis csak a böngésző, az operációs rendszer és a protokoll által lekorlátozott adatokat érhetik el. Nincs hozzáférésük például olyan adatokhoz, hogy melyik ügyfél azonosítóhoz kiosztott IP címről milyen lekérdezések érkeztek. Ezzel a rendelkezésre álló adatok csak egy részhalmaza érhető el, valamint az azonosítás nem minden esetben lesz triviális, de ezek az adatok szinte bárkiről elérhetőek. 


\section{Felhasználó azonosítása regisztráció esetén}

Bár a felhasználó bejelentkeztetésének több módja is lehet, minden esetben a lényeg, hogy a látogatót egy munkamenet azonosítóval lássuk el, aminek következtében a szerveren be tudjuk azonosítani. Az alábbiakban bemutatom, hogy milyen módjai vannak a látogató bejelentkeztetésének:

- Úrlapon keresztül: A bejelentkezésre szolgáló weblapra egy bejelentkező úrlapot helyeznek el, az ûrlap tartalma a bejelentkezés gombra történő kattintást követôen általában POST típusú - az átlagfelhasználó számára nem látható módon - lekérdezésben küldi el a böngésző a szervernek.

- Közösségi hálózatok vagy OpenID révén: Harmadik félnél tárolt személyes adatok átadása néhány kattintással az azt igénylő webhely számára

\section{A felhasználók azonosítása a közösségi hálózatok által}

Facebook Connect, Google+ Sign-In, Sign in with LinkedIn stb. a közösségi hálózatok egyik népszerú szolgáltatása. Segítségével a megfelelő bejelentkező komponenst tartalmazó weboldalon néhány kattintással regisztrálni lehet a weboldalon. Nem szükséges külön regisztrálni és a személyes adatainkat kézzel megadni, elég pl. az oldalon lévő Facebook-os regisztráció, majd a Facebook-os belépés gombra kattintani. Ezt követôen egy felbukkanó ablakban megjelenik a jól ismert Facebook bejelentkezési oldal, ha a felhasználó éppen nincs bejelentkezve, majd rákérdez, hogy a weboldal milyen adatokhoz férhet hozzá. Többek között hozzáférést lehet igényelni a felhasználó alapadataihoz, úgymint a neve, születési helye, tartózkodási helye, neme, profilképe stb. De lehetôség nyílik hozzáférni akár a felhasználó képeihez, barátlistájához vagy akár falához is (Facebook Developers, 2013). 2012. őszétől kezdve az weblapok és alkalmazások több különböző szintű hozzáférést is kérhetnek a felhasználók adataihoz. Ez azt jelenti, hogy a csatlakozni kívánó egyén számára nem feltétlenül szükséges az alkalmazás által kért össze hozzáférést megadnia. A felhasználónak lehetősége van kiválasztani, hogy mihez engednek hozzáférést. 


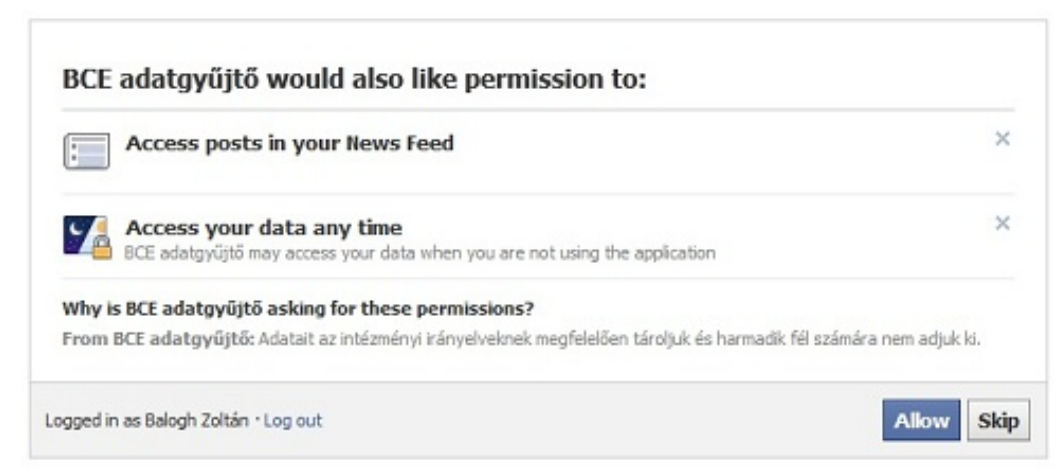

7. ábra, Egy harmadik fél által írt alkalmazás engedélyeket kér a Facebook-tól (saját felvétel)

Az adatok titkosításához és a hitelesítéshez a Facebook az OAuth 2.0 nyílt szabványt használja, melynek révén nyílik lehetőség a harmadik fél által fejlesztett alkalmazások számára a hozzáféréshez, anélkül, hogy a webalkalmazásnak bármilyen saját kulcsot vagy kódot ki kelljen adnia.

Az OpenID egy nyílt szabvány, amely a fentebb leírt közösségi oldalas regisztráció és bejelentkezésre hasonlít. A kettő közötti fő különbség abban rejlik, hogy ez az informatikai iparág nagyjai által létrehozott független bejelentetési szabvány keretrendszer. Hátránya, hogy kevésbé elterjedt, hozzávetőlegesen 190,000 weboldalon használható. (Built With, 2013)

A weboldalak az ûrlap és a Facebook Connect vagy Google+ Sign-in kombinációját szokták alkalmazni, néhány esetben lehetőséget biztosítanak az OpenID-vel rendelkező felhasználók számára is. Jelenleg egyik módszer elhagyása sem javasolt, mivel, ha az oldalon csak Facebook Connect regisztráció található, akkor a Facebook azonosítóval rendelkező nem rendelkező felhasználók nem fogják használni az oldalt.

\subsubsection{A rendelkezésre álló adatok}

Elméleti szinten rengeteg hozzáférhető adat létezik egy weblap számára, amelyek az alábbi kategóriákba egyikébe sorolhatóak:

- a böngészéshez használt hardver tulajdonságai

- a böngészéshez használt hardveren lévő szoftver környezetének tulajdonságai

- a böngészéshez használt böngésző tulajdonságai

- a felhasználó viselkedése vagy a felhasználóra jellemző tulajdonságok 
- harmadik fél által történő azonosítás

Az Internet böngészéséhez használt - a hardver és az operációs rendszer felett elhelyezkedő - célalkalmazás a böngésző. A böngésző a webszervertől letöltött HTML állományok letöltésére és megjelenítésére szolgál.

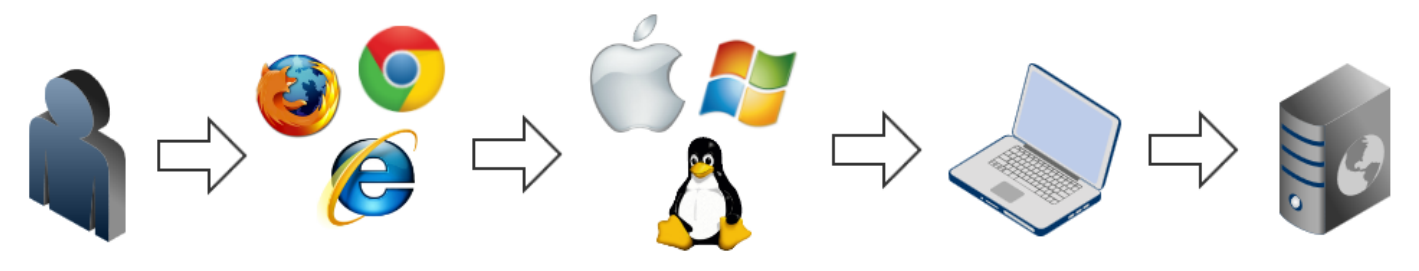

8. ábra, a látogató és az Internet közötti kapcsolat (saját szerkesztés)

A 8. ábra, a látogató és az Internet közötti kapcsolat látható módon éri el a felhasználó az Interneten található weboldalt, a köztes szoftver és hardver elemeket használja. Ezek az elemek egymás számára szolgáltatásokat nyújtanak és vesznek igénybe. A weblapok számára minden egyes elem attribútumainak egy része elérhető, némely tulajdonságokat pedig szándékosan elrejt a következő réteg.

\subsubsection{A hozzáférhetó adatok}

Az eddig bemutatott adatok elviekben hozzáférhetőek, azonban a gyakorlat azt mutatja, hogy bizonyos adatokhoz a böngészők sem férnek hozzá vagy azt szándékosan nem teszik hozzáférhetővé a weblapok számára. Ez természetesen böngészőnként és platformonként is változhat. (pl: az Apple termékek nem támogatják a Flash lejátszókat, így annak verziószáma, valamint a rendszerre telepített betútípusok listája nem lesz elérhető vagy bizonyos HTML5 képességek a böngészők ${ }^{18}$ asztali verziójában szintén nem elérhetőek).

A személyes jellegű adatok esetében felhasználói beleegyezés szükséges azok eléréséhez. (pl: GeoLocation, közösségi hálózatról hozzáférhető adatok) Általában ezeket a látogatók nem szívesen osztják meg a weboldallal.

\footnotetext{
${ }^{18}$ nem elérhető a böngészéshez használt kapcsolat típusa
} 
$\leftarrow \rightarrow$ C $[$ slides.html5rocks.com/\#geolocation

‥ A(z) slides.htmI5rocks.com az Ön számítógépének helyadatait akarja használni. Engedélyezés Megtagadás

9. ábra, a Chrome engedélyt kér a látogató földrajzi pozíciójához (saját felvétel)

Az inkognitó mód (3.1.1/Az inkognitó mód) detektálása régebben a „CSS history sniffing" technika segítségével volt lehetséges (Stack Exchange, 2011), azonban ezt a biztonsági rést mára már az összes böngésző́ben javították, így ennek detektálására már nincs lehetôség. Korábban a következő módon volt lehetséges annak detektálása: normál esetben, ha a látogató egy linkre kattintva, majd a vissza gombra kattintva ugyanazon az oldalon lévő link színe megváltozik, jelezve a felhasználó számára, hogy a link mögött lévő oldalt a felhasználó már egyszer meglátogatta. Ha ezt a múveletet Javascript segítségével idézte elő az alkalmazás fejlesztője és a végén lekérdezte, hogy az adott link színe megváltozott, akkor máris megkapja a választ arra a kérdésre, hogy a látogató inkognitó módban használja-e a böngészőjét. A dolog múködésének megértéséhez tudni kell, hogy az inkognitó mód célja az, hogy miután a felhasználó bezárta a böngészőt az eszközön ne maradjon nyoma a böngészésének. Azonban ezt a hibát mára már befoltozták, így nincs lehetôség az annak detektálására, azaz nem lehet a felhasználót arra kényszeríteni, hogy ne használjon inkognitó módot és nyoma maradjon a gépen és ebből kifolyólag követni lehessen a későbbiekben. Érdekességként jegyzem meg, hogy bár az inkognitó mód használatával a böngésző minden nyomot megpróbál eltüntetni a gépről, a meglátogatott domain-ek listája (Windows alapesetben 5 percig) a DNS resolver gyorsítótárában megtalálható az eszközön.

A függelék 8.6 fejezetében található táblázatban foglaltam össze a lényegesebb paraméterek használatának előnyeit és hátrányait.

A HTML5 és CSS3 képességek jelentôs részét alap Javascript segítségével is lehet detektálni, azonban a Modernizr JS library segítségével egységesített formában egy objektum attribútumainak lekérdezésével érhető el. A különböző beépülő modulok detektálása és verziójának lekérdezését szintén célszerú egy erre szakosodott library-val végeztetni. Mivel az egyes képességek teljes mértékben összefüggenek a különböző böngészők és azok verzióival, így azok nem járulnak hozzá a felhasználó pontosabb azonosításához, emiatt ezen adatok lementése csak akkor szükséges, ha az oldal látogatóinak böngészőjének képességeiről szeretnénk statisztikát készíteni. 
A billentyưzet és egérmozgás figyelése a kliensoldalon erőforrás-igényes múvelet, ezért a gyakorlattban az összegyújtött adatok tömörítésére lehet szükség a szerverre való átküldés előtt.

A harmadik féltől lekérdezhető adatok jellemzőit a 4. táblázat: harmadik féltól lekérdezhetô paraméterek elönyei és hátrányaban foglaltam össze. Az adatok közös jellemzője, hogy API-n keresztül a felhasználó vagy az általa használt eszköz egy tulajdonságával kérdezhetóek le.

\begin{tabular}{|c|c|c|}
\hline Megnevezés & Előny & Hátrány \\
\hline ISP & $\begin{array}{l}\text { kikövetkeztethető belőle az } \\
\text { internetezéshez használt } \\
\text { hálózati kapcsolata, bizonyos } \\
\text { esetekben a kapcsolathoz az } \\
\text { internetet } \\
\text { intézmény }\end{array}$ & \\
\hline Proxy & $\begin{array}{l}\text { ha az illetô proxy-t használ a } \\
\text { kapcsolathoz a használt IP } \\
\text { címe csak a munkamenet } \\
\text { azonosítására használható, } \\
\text { mert az nem a valós }\end{array}$ & $\begin{array}{l}\text { NAT mögötti eszköz } \\
\text { detektálására nem használható }\end{array}$ \\
\hline $\begin{array}{l}\text { Blacklist check } \\
\text { / tiltólistán való } \\
\text { jelenlét }\end{array}$ & $\begin{array}{l}\text { megtudható, hogy az adott IP } \\
\text { cím valamelyik spam } \\
\text { tiltólistán szerepel }\end{array}$ & \\
\hline $\begin{array}{l}\text { Közösségi } \\
\text { oldalakon } \\
\text { hozzáférhetó } \\
\text { adat }\end{array}$ & $\begin{array}{l}\text { rengeteg hasznos } \\
\text { felhasználóra jellemző } \\
\text { információt lehet letölteni }\end{array}$ & $\begin{array}{l}\text { felhasználói hozzájárulás } \\
\text { szükséges a hozzáféréshez, } \\
\text { nehéz rábírni a felhasználókat } \\
\text { adataik megadásához }\end{array}$ \\
\hline $\begin{array}{l}\text { Egyéb } \\
\text { harmadik féltől } \\
\text { lekérdezhető } \\
\text { adat }\end{array}$ & $\begin{array}{l}\text { szolgáltatótól függően az } \\
\text { adatok személyhez vagy } \\
\text { eszközhöz köthetőek }\end{array}$ & $\begin{array}{l}\text { ha a lekérdezés kulcsa az IP } \\
\text { cím, nem biztos, hogy a } \\
\text { lekérdezés releváns találatot } \\
\text { szolgáltat }\end{array}$ \\
\hline
\end{tabular}

4. táblázat: harmadik féltól lekérdezhetô paraméterek elönyei és hátránya

A lekérdezendő adatok megállapításához célszerú tesztelni, hogy mely paraméterek milyen mértékben járulnak hozzá az egyedi böngésző ujjlenyomat előállításához. Abban az esetben, ha valamelyik paraméter egy másikkal korrelál (mint a böngésző típusa, verziója és a HTML5, CSS3 képességei) az elhagyható. A 
gyakorlatban az azonosítást és felhasználó követését lehetővé tevő lekérdezhető adatok körének megállapítása üzleti érdekek és technológiai megvalósíthatóság mentén létrejövő konszenzus.

- A környezeti változóként vagy Javascript segítségével elérhető adatok csoportjába tartozó elemek (aktuális böngészőablak méretének kivételével) mindegyikét célszerü lekérdezni, mivel elérésük nem hardverigényes és az eszközböngésző beazonosításában kulcsszerepet játszanak, valamint ezen adatok segítségével érhetőek el a harmadik félnél tárolt adatok többsége. A generált eszközböngésző azonosító teszi teljes mértékben bizonyossá, hogy az aktuális eszközböngészőről már meglátogatták a weboldalt.

- A felhasználóra jellemzó billentyűzet és egérfigyelés előnye, hogy felhasználót képesek azonosítani, azonban a fejlesztés során arra is gondot kell fordítani, hogy az egér és a billentyúzethasználatból származó adatok az oldalletöltések között is megmaradjanak. Szintén az azonosítás pontossága érdekében az adatgyújtés többször érdemes elvégezni, valamint biztosítani kell, hogy a felhasználó megfelelő mennyiségú mintát adjon le. Kerülni kell azokat az eseteket, amikor a felhasználó valamilyen eseményre való reakciójaként nyom le egy billentyút vagy kattint az egérrel, (pl: játék közben) mert ezek nagyban ronthatják az azonosítás pontosságát.

- A komplex paraméterek (telepített betúkészletek, billentyűzet és egérhasználat) csoportjába tartozó elemek erőforrás- és sávszélességigényesek lehetnek, ezért nem minden esetben javasolt a használatuk. A telepített betúkészletek listájának lekérdezéséhez Flash lejátszó szükséges, amely az Adobe állítása szerint a desktop PC-k 99\%-án található Flash lejátszó. (Adobe, 2011) Más források 92-95\% közé teszik az elterjedtségét földrajzi hely függvényében. Az operációs rendszerek piaci részesedése a 10. ábra látható, amiből az derül ki, hogy a Mac OS X elterjedése 6,65\%-os, tehát ezeken a gépeken biztosan nem lehetséges a betúkészlet detektálása, mivel ezek nem támogatják a Flash lejátszót. 


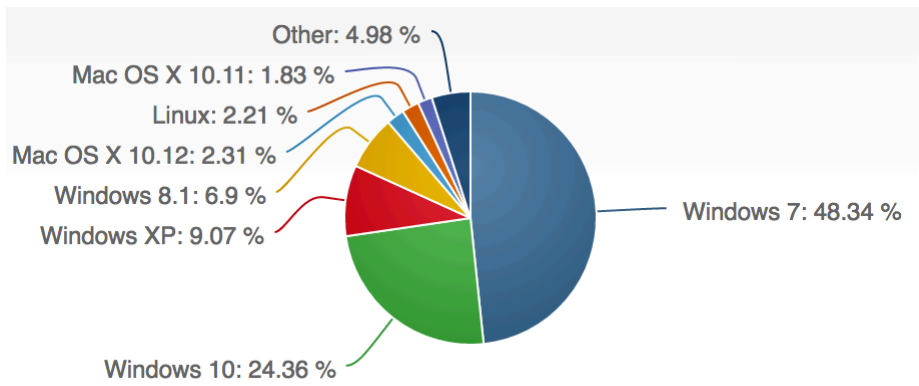

10. ábra, asztali operációs rendszerek piaci részesedése 2016-ban (NetMarketShare, 2016)

- A harmadik féltől lekérdezhetô adatok egy részének (proxy, blacklist check és egyéb harmadik féltől lekérdezhető adat) pontossága megkérdőjelezhető, tehát semmiképpen nem kezelhető biztos adatforrásnak abban az esetben, ha annak hitelességét más forrás nem erősíti meg. A közösségi hálózatokon található adatok megosztásához engedélyt kell kérni először a látogatótól, személyes tapasztalataim azt mutatják, hogy a felhasználók csak csekély százaléka engedi egy külső oldal számára, hogy a Facebook-os adataihoz hozzáférjen. A Brafton felmérése szerint azonban a jelenlegi tizenéves generáció 91\%-a rak ki képeket a Facebook-ra rendszeresen, ugyanez a mutató 2006-ban 69\% volt. (Brafton Editorial, 2013) Ami valószínúsíthetően magasabb hozzájárulási hajlandósággal jár együtt.

Az adatokat többféle forrásból nyerhetjük ki:

- A HTTP fejlécben elküldött adatok: minden egyes lekérdezéssel együtt a lekérdezés fejlécében a szerverre utazik az eszköz hardverének és operációs rendszerének bizonyos paraméterei

- A Javascript segítségével kiolvasható tulajdonságok: a böngésző DOMjából Javascript segítségével olvasható ki, majd ezt követőn AJAX lekérdezéssel lehetséges a szerverre elküldeni azt

- A harmadik féltől megszerezhetó adatok: valamilyen eszközre vagy felhasználóra jellemző tulajdonság egy harmadik fél által történő lekérdezése a szerveren 


\subsubsection{A felhasználói életút vizsgálata}

Az ugyanazon látogatók egy munkamenetéhez tartozó lekérdezéseinek összekapcsolása egyszerú, hiszen minden lekérdezés fejlécében benne van a munkamenet azonosítója. Szélsőséges esetben előfordulhat, hogy egy munkamenet azonosító csak egy személyhez tartozik.

Amennyiben munkamenet azonosító nem áll rendelkezésre vagy a nyomkövetéshez használt süti vagy a localStorage-ben tárolt adat megsérül vagy elérhetetlenné válik, a látogatóra jellemző paraméterek alapján érdemes az összekapcsolást elvégezni. Ha ez sem lehetséges, a böngészó és az eszközböngésző paraméterei segíthetik a látogatók követését és munkameneteinek összekapcsolását.

Bár a magyar nyelvben nincs megfelelő kifejezés a weboldalak összessége és egy konkrét weblap megkülönböztetésére, a továbbiakban a webhely kifejezést az azonos domain alatt elérhetô oldalakra értem, a weblap kifejezést pedig egy konkrét oldalra. Egy webhely lehet például a WizzAir légitársaság honlapja és egy weblapra pedig a WizzAir webhelyének jegyfoglalási oldala. A webhelyek tehát weblapokból állnak, amelyeket gráf formában ábrázolhatunk, a csúcspontok maguk az weblapok és az élek a köztük lévő linkek. A 11. ábrán egy olyan honlap látható, amelyet fa struktúrában is lehet ábrázolni, azonban ez nem mindig teljesül, lehetnek olyan aloldalak is, amelyek egy másik aloldalra hivatkoznak.

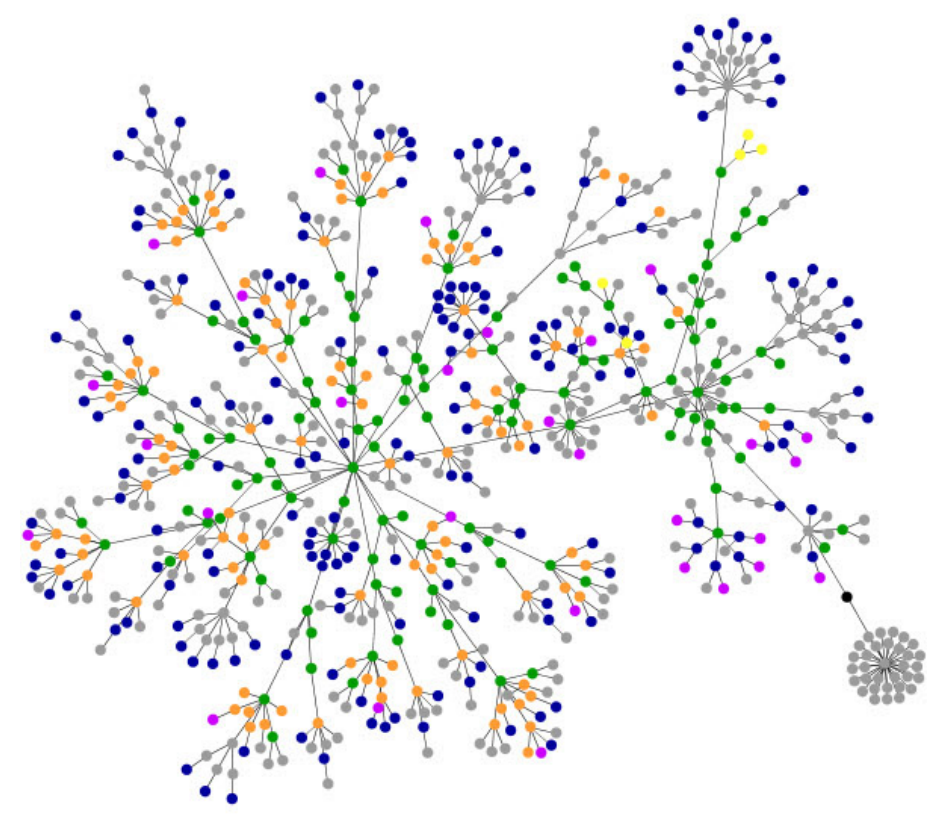

11. ábra, Egy webhely weblapjainak gráf formában történó ábrázolása (saját szerkesztés) 
A felhasználó a böngészés során egy honlap oldaltérképet különbözőképpen járhat be, ezt a bejárást nevezzük a webhely bejárásának, ami a webhelyen található első weboldal megtekintésétől annak elhagyásáig tart. Több kutatás is megerôsítette, hogy a webhelyek bejárásának módja jellemző lehet az egyénre. (Shababi, Zarkesh, Adibi, \& Shah, 1997)

Az következőkben a webhely bejárásának lehetséges fázisait elemzem a felhasználó azonosításának szintje szempontjából. Minden esetben értékelni fogom, hogy az adott fázisban

- ismert-e látogató kiléte, milyen mértékú a nyomonkövethetősége

- van-e lehetőség az eszközböngészők összekapcsolására

- ismert-e a felhasználó üzleti szempontból lényeges tulajdonsága.

\section{A bejelentkezés nélküli böngészés}

A megtekintett webhelyen nincs bejelentkezési lehetőség vagy a látogató nem jelentkezett be. Webáruházaknál gyakran alkalmazott technológia, hogy a látogató a webhely első weblapjának meglátogatása során kap egy munkamenet azonosítót és a virtuális kosarába pakolhatja a termékeket és csak akkor kell bejelentkeznie, ha tényleg meg is szeretné vásárolni a kívánt termékeket. Előnye, hogy a látogató nincs rákényszerítve, hogy már a terméklista böngészése előtt regisztráljon vagy belépjen, elég akkor, ha már fizetni szeretne. A munkamenet kiosztásának következményeképpen a webhely képes követni a felhasználóit.

\section{A bejelentkezett felhasználó böngészése}

A bejelentkezést követően az aktuális látogató kiléte elérhetővé és azonosíthatóvá válik a weblapok számára. Ez egyben egy logikai és adminisztratív védelemmel látja el a weblapot. (András \& Péter, 2015)

Miután a látogató bejelentkezett a webhelyre, a nyomkövetése egyszerúvé válik, ugyanis a munkamenetben megtalálható azonosítója segítségével a rendszerben tárolt adatok közül egyszerűen kiválasztható a felhasználóhoz köthető adat, amelyet a regisztráció folyamata során előzőleg megadott magáról.

Ha a látogató különböző eszközökről is bejelentkezik, akkor az eszközböngészők egymáshoz kapcsolása is egyszerű, hiszen a lementett adatokból csak le kell szúrni a felhasználóhoz kapcsolható különböző eszközböngészóket.

\section{A kijelentkezés utáni böngészés}


A kijelentkezést követóen a munkamenet azonosító és annak tartalma a szerveren törlődik, így már nem elérhető az látogatóhoz kapcsolható azonosító. Azonban nincs garantálva, hogy a felhasználó valóban ki lesz jelentkeztetve és a munkamenete törölve lesz, mint ahogyan 2013. februárjában egy hacker bebizonyította, hogy a Facebook nem először a kijelentkezés után is adatokat gyújt a felhasználóiról. (Hobson, 2013)

Ha a kijelentkezés valóban megszünteti a munkamenetet, szintén nem túl bonyolult feladat a látogató későbbi életútját a szoftver és hardverkörnyezete alapján hozzákapcsolni, mivel ebben az esetben igen kis időtartamról beszélünk, ezért élhetünk azzal a feltételezéssel, hogy a látogatóról elmentett adatok jelentős része nem módosult.

Egyazon bejelentkezési azonosítóhoz tartozó különböző eszközböngészők összekapcsolása a bejelentkezési azonosító miatt lehetséges, ez az információ kijelentkezést követően is megmarad.

\subsection{Látogatók azonosításának és követésének módszerei}

Az irodalom az egyének beazonosításra két módszert említ:

- Felülról lefelé: A teljes emberi populációból kiindulva szúkíti a kört addig, amíg meg nem találjuk a keresett egyént (Eckersley, 2013)

- Egyén a tömegben: $\mathrm{Az}$ emberek egyedi mobilitási képességein és viselkedésén alapuló eljárás (D. Blondel, A. Hidalgo, Verleysen, \& de Montjoye, 2013)

A látogatókról kinyerhető adatok tárgyalását követően, belőlük építkezve lehetséges a látogatók által használt eszközböngészők összekapcsolása vagy a felhasználók profilozása. A felhasználók azonosítására és az eszközböngészők összekapcsolására több lehetőség nyílik, ezeket az alábbi csoportokba lehet rendezni:

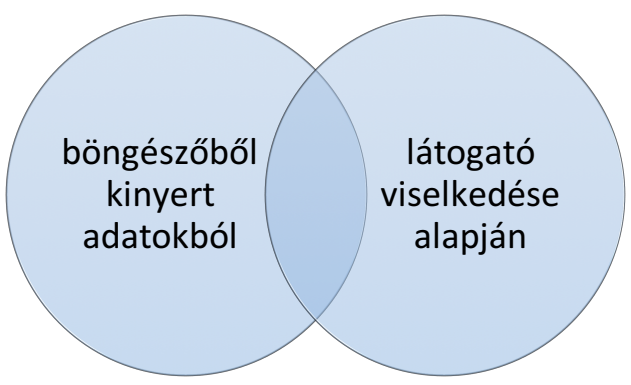

12. ábra, Azonositás módszereinek egymáshoz való viszonya (saját szerkesztés) 
- a böngésző által szolgáltatott adatokból kinyerhető információ segítségével: a böngésző által küldött adatokból megismerhető a látogató által az aktuális munkamenethez használt eszközböngésző szoftver és hardver környezete. Ezzel csak az eszközböngészőt lehet beazonosítani, amivel az a probléma, hogy egy látogató több eszközböngészőt használhat és több felhasználó is használhat egy eszközböngészőt. (N:N kapcsolat) Így ez a módszer nem jelent tökéletes megoldást a problémára, azonban jelentősen lehet szúkíteni az eredményhalmazt.

- viselkedés alapú: a látogató online viselkedése meghatározhatja az egyént. Minél több információnk van a felhasználó böngészési szokásairól, annál pontosabban beazonosítható az egyén.

- Kombinált módszer: az előbbi módszerek kombinálásával elérhető azonosítás

\subsubsection{A böngészó által szolgáltatott adatokból kinyert információ segítségével}

Előzőleg már megismertük, hogy milyen adatokat milyen módszerrel lehet kinyerni a látogató böngészőjéből. Fontos kiemelni, hogy egy hardver beazonosítása és követése nem jelent egyet a böngésző felhasználó azonosításával, mivel egy személynek több különböző eszköze is lehet, vagy az is előfordulhat, hogy más használja egy másik személy számára. Az alábbi táblázatban összefoglaltam, hogy az egyes azonosítási módszerek mit azonosítanak. Ennek megfelelő ez lehet

- eszköz: az internetezésre használt hardver és rajta lévő szoftverek (pl: mobiltelefon Android operációs rendszerrel vagy laptop Windows 7 operációs rendszerrel stb.)

- böngésző: az internetezéshez használt böngésző alkalmazás (Opera vagy Firefox stb.)

- személy: a hardvert használó személyre jellemző

A következőkben azt vizsgálom, hogy a megszerzett adatok segítségével hogyan lehet azonosítani, illetve követni a látogatókat, majd az alább látható táblázatban összefoglaltam, hogy a felsorolt azonosítási módszerek közül mely az, amely az eszközböngészőt azonosítja, meg az, amely az eszközt és melyik az, amely a felhasználót azonosítja. 
Fontos különbséget tenni az eszközböngésző és az eszköz azonosítása között, ugyanis előfordulhat, hogy valaki kölcsönadja a gépét egy másik személy számára, ezért, ha az egyik módszerrel beazonosítottuk az eszközböngészőt, még nem biztos, hogy azzal beazonosítottuk a felhasználót is.

\begin{tabular}{|c|c|}
\hline Azonosítási módszer & $\begin{array}{c}\text { Mit azonosít? } \\
\text { (eszközböngésző, eszköz, } \\
\text { felhasználó) }\end{array}$ \\
\hline Lokáció alapú & eszköz \\
\hline \multicolumn{2}{|l|}{ Szoftver- és hardverkörnyezet } \\
\hline $\begin{array}{l}\text { Képernyő szélessége, magassága és } \\
\text { bitmélysége }\end{array}$ & eszköz \\
\hline Operációs rendszer típusa és verziószáma & eszköz \\
\hline Böngésző típusa és verziószáma & eszköz \\
\hline Eszköz típusa és verziószáma & eszköz \\
\hline HTTP fejléc & eszközböngésző \\
\hline HTML5 \& CSS3 képességek & eszközböngésző \\
\hline Cache alapú & eszközböngésző \\
\hline $\begin{array}{l}\text { Cookie, localStorage vagy egyéb WebStorage } \\
\text { alapú }\end{array}$ & eszközböngésző \\
\hline Telepített betútípusok & eszköz \\
\hline \multicolumn{2}{|l|}{ Viselkedés alapú } \\
\hline meglátogatott webhelyek alapján & felhasználó \\
\hline webhely bejárásának módja alapján & felhasználó \\
\hline billentyưzethasználat alapján & felhasználó \\
\hline egérmozgás követés alapján & felhasználó \\
\hline Közösségi hálózatok által & felhasználó \\
\hline Egyéb harmadik féltől hozzáférhető adat & felhasználó \\
\hline
\end{tabular}

5. táblázat: azonositásra használható paraméterek és azonosításuk tárgya

Az alábbiakban bemutatom a fontosabb böngészó által kínált nyomkövetésre használható adat típusokat. Az adatok egy részét Javascript segítségével a DOM-ból lehet kiolvasni, a másik részét pedig a HTTP fejlécből kiolvasni. 


\section{Lokáció alapú nyomkövetés}

A látogató aktuális földrajzi pozíciójának meghatározására több módszer létezik. Egy hozzávetőleges földrajzi pozíciót az IP címből vissza lehet fejteni. Az IP címek kiosztása nem hierarchikus, azaz két egymás mellett IP cím nem jelenti azt, hogy földrajzilag is közel helyezkednek el egymáshoz. Ez a telefonszámok esetében igaz, ugyanis az ugyanabban a körzetben található kiosztott telefonszámok csak az adott körzeten belül fordulhatnak elő. Azonban léteznek olyan elérhető adatbázisok, melyek összerendelik a kiosztott IP címeket a földrajzi pozíciójukkal. Ebből az adatbázisból létezik ingyenes tartomány/város szintú, de a fizetôs verzióban megtalálható akár az utca szintű felbontás is.

Az IP címek visszafejtéséhez az adatbázisban vissza kell keresni a látogató IP címét és az visszaadja annak földrajzi helyét a megfelelő pontossággal. Természetesen, ha a látogató valamilyen mobil eszközről éri az Internetet, akkor a módszer nem lesz pontos.

Sokkal pontosabb eredményt ad vissza a HTML5 GeoLocation szolgáltatása. Ez a HTML5 megjelenése elôtt a Google Gears-ben ${ }^{19}$ kísérleti jelleggel indult el, majd bekerült a HTML5 szabványba. Azért jóval pontosabb, mert ez a módszer nem az IP címből fejti vissza a földrajzi pozíciót, hanem a böngészéshez használt eszköz valamely földrajzi pozíciójának megállapítására alkalmas részegységétől kérdezi le az eszköz helyzetét. Egy mobil eszközben általában több olyan eszköz is megtalálható, amely segítségével megállapítható annak helyzete:

- GPS/GLONASS: akár méteres vagy deciméteres pontosság is elérhető

- Wifi/Bluetooth/NFC: különböző adatátviteli technológiák segítségével, a csatlakoztatott állomások pozíciójának ismeretében lehetséges a látogatáshoz használt eszközböngésző körülbelüli pozíciójának megállapítása

- rádiótelefon cellainformáció: amennyiben mobiltelefonról beszélünk, a hálózatra kapcsolt eszköz a 3 legközelebbi adótornyok pozíciójának ismeretében háromszögelés módszerével ki tudja számítani annak megközelítőleg pontos földrajzi pozícióját.

\footnotetext{
${ }^{19}$ A Google által 2007. május 31-én kiadott kiegészítő böngészőkhöz, a HTML5 megjelenése elôtt RIAk (Rich Internet Application) számára biztosította a HTML5-ben megjelent lehetőségek egy részét (pl: GeoLocation, localStorage, SQLite, Worker, application cache)
} 
A fenti listából a GPS/GLONASS adja vissza a legpontosabb eredményt, azonban egy mobil készülékben nem feltétlenül van mindig bekapcsolva, valamint felhasználói hozzájárulás is szükséges. Városi környezetben, ahol a mobiltelefon cellák sûrün helyezkednek el, a háromszögelés módszerével is 10-20 méteres pontosság érhető el, akár fedett területen belül is. Egy GPS képes mobiltelefon esetében mindig a legpontosabb elérhető eszközt választja ki a helyzet meghatározásához.

A GeoLocation API kétféle lehetősége kínál:

- aktuális helyzet lekérdezése

- felhasználó helyzetének követése

\section{Cache alapú nyomkövetés}

A sütik használatának hátránya, hogy könnyen törölhető a kliens eszközböngészőjéből. Nyomkövető sütik használatához pedig a felhasználó beleegyezését kell kérni. (Alexander, 2012) Azonban léteznek alternatív módszerek is a felhasználók követésére, egyik ilyen módszer a cache alapú azonosítás. A múködés elve:

1. A felhasználó meglátogatja a webhelyet első alkalommal.

2. A letöltött weblap tartalmaz egy linket, amely egy külső JS file-ra mutat. A JS file nevét a szerver generálja és a szerveren az eszközböngészőhöz társítva elmentésre kerül. A JS file-t nem szabad cache-elni, mert a módszer előfeltétele, hogy minden alkalommal a böngésző leellenőrizze a JS file-t.

3. Böngészés közben a böngésző megkísérli letölteni a JavaScript file-t, amelyre a szerver HTTP 301-es hibaüzenetet küld vissza. A HTTP 301-es hibaüzenet azt jelenti, hogy a kért erőforrást áthelyezték ("Moved Permanently") és a HTTP válaszban benne lesz az erőforrás új helye.

4. A böngésző az új helyről letölti a JS file-t, amely képes betölteni eredeti funkcióját.

Ezzel az egyszerú trükkel nem szükséges a munkamenet sütik használata. A szerver a már előzőleg kiosztott azonosítót minden oldalletöltéskor meg fogja kapni, amikor a böngésző megpróbálja letölteni az oldal múködéséhez szükséges állományt. Maga az eszközböngésző azonosító a lekérdezni kívánt file neve lesz. Ez a módszer a cookie-s azonosításhoz képest 
- sokkal sebezhetőbb, mivel, ha a felhasználó kitörli a cache-t vagy Ctrl-F5-tel (force refresh) frissít az oldalra néhány böngésző esetében új nyomkövetô azonosítót generál a szerver. Inkognitó módban nem használható.

- sokkal kevésbé blokkolható, egyelőre nem ismerik ezt a technikát a privacy filterek.

- a cookie-kal ellentétben ezt a módszert még nem szabályozzák a törvények.

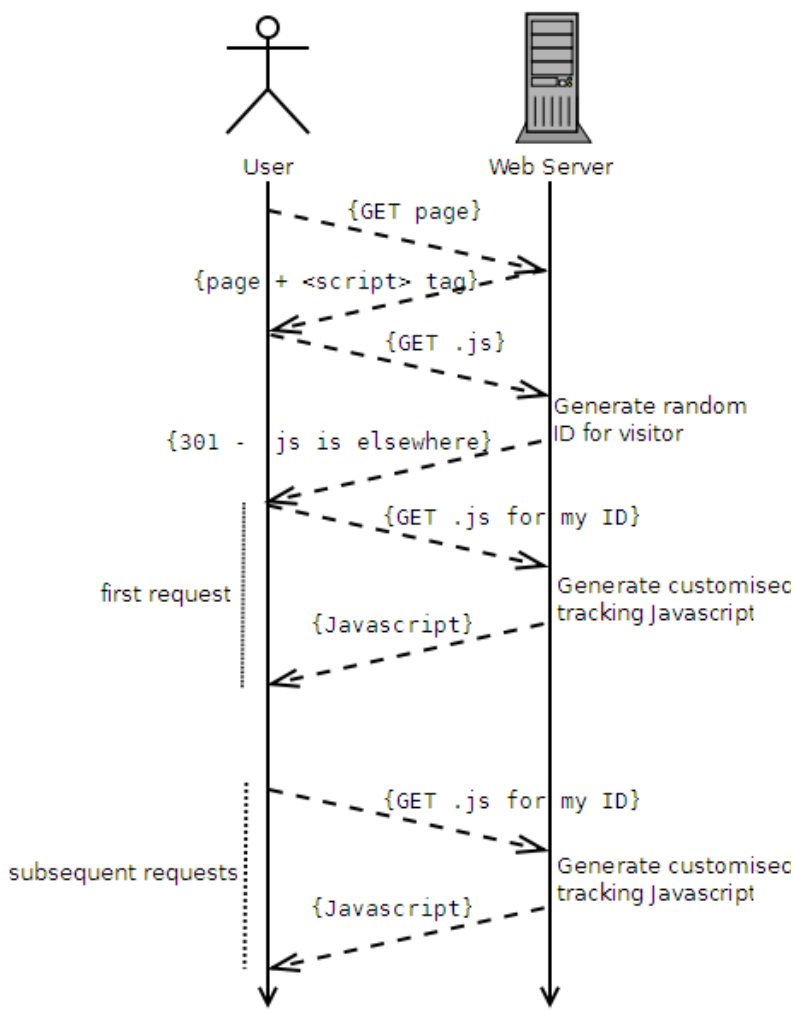

13. ábra, Cache alapú azonositás

\section{A cookie, localStorage vagy egyéb WebStorage alapú nyomkövetés}

A legelterjedtebb módszer a felhasználók követésére a süti alapú nyomkövetés. A múködése nagyon egyszerú:

- elsô látogatás alkalmával a szerver egy egyedi kódot küld a kliens számára, amelyet az eltárol egy sütiben

- az oldalletöltések során a süti minden HTTP fejlécben el lesz küldve a szerver számára, ahol a fogadó alkalmazás az adatbázisból kikeresheti, hogy melyik felhasználóhoz tartozik az adott azonosító.

A localStorage, sessionStorage és más WebStorage alapú nyomkövetés esetében is ugyanígy múködik, a kliens oldali azonosító tárolásában különböznek egyedül. 


\section{A telepített betútípusok alapján történô nyomkövetés}

Korábban már bemutatott telepített betütípus lista lekérdezésének feltétele, hogy a kliens böngészőjére fel legyen telepítve Flash Player (ugyanis a JavaScripttel ellentétben a Flash képes lekérdezni az eszközre telepített betútípusok listáját). Müködése:

- A weboldal letöltődésekor az onDOMReady eseményt kiszolgáló függvényből kell meghívni a Flash modult, amely lekérdezi az eszközre telepített betútípusokat (Ali, 2010)

- A múvelet végeztével a Flash meghív egy JavaScript függvényt, amelynek átadja a betűtípusok listáját

- A kapott listát a JavaScript egy AJAX lekérdezéssel elküldi a szerver számára

Mivel ez a lista csak betûtípusok telepítése során változik (bővül) ezért rövid időtávon alkalmas a felhasználók követésére. Nagy előnye, hogy nem eszközböngészőt, hanem eszközt azonosít. Hátránya, hogy nem múködik Apple termékeken, Flash modul használata nélkül vagy Flash blokkoló használata esetén. Az Adobe bevallása szerint a Flash Player elterjedése 99\%-os a PC-ken. (Adobe, 2011)

Egy operációs rendszerre telepített programokkal több az adott alkalmazásra jellemző betûtípus is települhet, ez szintén azonosíthatja az eszközt. A betűtípus lista lekérdezésének feltétele, hogy a kliens böngészőjére fel legyen telepítve Flash Player (JavaScripttel nem lehet lekérdezni a telepített betútípusok listáját).

\subsubsection{A viselkedés alapú nyomkövetés}

A viselkedés alapú nyomkövetési módszerek közös jellemzője, hogy a felhasználót képesek azonosítani. Múködési elve azon alapszik, hogy a látogató a viselkedésében hordozza az egyediséget, amely a megfelelő módszerekkel azonosíthatóvá válik. A kutatásaim során az alábbi módszerekre bukkantam:

\section{Meglátogatott weblapok alapján történő nyomkövetés}

Az internethasználókra, mint egyénekre jellemző, hogy azokat a weblapokat látogatják meg, amelyek őket érdekli. Az egyéneket az ilyen fajta internet használati szokásuk szerint is lehet csoportosítani. Azonban a felhasználók különböző eszközökről történő tartalomfogyasztása akár jelentős mértékben eltérhet egymástól. A látogatók böngészési előzményeiből az alábbi jellemzők lehetnek alkalmasak a felhasználó nyomkövetésére: 
- Az egyén által meglátogatott webhelyek listája

- Az egyén által meglátogatott webhelyek illetve weboldalak látogatásának sorrendje

- Milyen eszközökról és honnan látogatja meg az egyén az adott webhelyet/weboldalt

A látogatók által meglátogatott weblapok teljes listája a böngészőből kiolvasva biztonsági okok miatt nem lehetséges. A közösségi hálózatok - mint a Facebook amelyeknek sok weboldalba be van ágyazva egy komponense, minden látogatás alkalmával elküldi a Facebook számára a meglátogatott weboldal címét, így pontosabb kép alkotható a látogatók böngészési szokásairól. Minél több weboldalba van beágyazva egy közösségi oldal komponense, annál pontosabb képet kaphat a közösségi oldal a felhasználói által látogatott weboldalak köréről.

\section{A webhely bejárásának módja alapján}

A meglátogatott webhelyek bejárásának módja szintén jellemző lehet az egyénre. A különféle weboldal bejárási módok csoportosíthatóak és szintén használható az egyén nyomkövetésénél bizonytalanság csökkentésére.

\section{Az egérmozgás és billentyúzethasználat alapján}

A biometrikus azonosítás azon alapszik, hogy minden egyénnek saját használati szokásai vannak, az emberi lét és viselkedés paramétereit használja ki. A billentyưzethasználat esetén kijelenthető, hogy a különféle emberek gépelési sebessége között van különbség. Elemzések szerint 300 karakter begépelését követôen már elegendő adat gyưlik össze ahhoz, hogy valakinek elkészítsék a profilját. A módszer az esetek 96\%-ban múködik helyesen. (Peter, David, David, Warren, \& Jonathan, 2005) Az egérmozgást követő kísérletek esetében 20 kattintás elegendő volt ahhoz, hogy az algoritmus csak 1,3\%-ban tévedjen. (Shivani, 2004) (Nan, Aaron, \& Haining)

\section{A közösségi hálózatok által történő követés}

A közösségi hálózatokról lekérhető adatok minden esetben egyértelmúen azonosítják a látogatókat, azonban ehhez szükséges a felhasználók hozzájárulása, amelyet a felhasználók elenyészó százaléka ad meg, még akkor is, ha egy megbízható oldalról van szó. A kísérletemben nyereményjátékkal próbáltam ösztönözni a felhasználókat privát adatait megadására. Kutatásom során azt tapasztaltam, hogy egy 
a felhasználók által jól ismert oldal esetén is csak kevesen engednek hozzáférést az adataikhoz.

\section{Egyéb harmadik féltől hozzáférhetó adat alapján}

A közösségi hálózatokon kívül más harmadik fél is használható a látogatók azonosítására. Amíg a közösségi hálózatoknak ez az egyik szolgáltatása, az ebbe a kategóriába kerültek azok az oldalak, amelyek a látogatókról valamilyen információt tárolnak és potenciálisan hozzásegíthetnek az egyének beazonosításához:

- youhavedownloaded.com egy olyan oldal, amely arról vezet naplót, hogy milyen IP címről mikor töltöttek tartalmakat. Az oldal jelenleg nem elérhető, de statisztikájuk szerint 55 millió felhasználóról tárolnak közel 115 TB-nyi adatot.

- Shodan: gonosz Google-nek is hívják, IP címre lehet rákeresni és az oldal visszaadja, hogy az adott IP címen milyen portok vannak nyitva, vagy milyen IP kamerák elérhetóek

- Whatismyip.com oldalról kinyerhető, hogy a látogató a webhely eléréséhez proxy-t használt-e, valamint, hogy az adott IP cím tiltólistán van-e

\subsubsection{A látogató azonosítása és követése}

Dolgozatomban a látogató követésének nevezem azt a folyamatot, amikor az eszközböngészők által létrehozott munkamenetek közötti kapcsolat kimutatható. A látogató azonosításán értem azt a folyamatot, amikor a látogató önkéntesen megadott adatai alapján, az internetezéshez használt eszközének szoftver és hardverkörnyezetének alapján vagy a látogató viselkedésének jellemzőiből a látogatóra egyértelműen következtetni lehet.

Egy látogató követéséhez szükséges ismerni az általa használt eszközböngészőket. Alapfeltevésként fogadjuk el, hogy a felhasználók több internetezésre alkalmas készülékkel rendelkezhet. Ezeket a készülékeket más személyek is használhatják, de abból indulok ki, hogy az esetek nagy részében egy látogató a saját készülékét használja.

Feltételezhetjük, hogy a felhasználók zöme legalább nem változtatja meg szándékosan az általa használt eszköz szoftverkörnyezetét, hogy az a nyomkövető alkalmazást megtévessze. Szintén nem életszerú, hogy a látogató a munkamenete ideje alatt a detektálható paramétereinek jelentős részét megváltoztatja. 
A látogató által használt különböző eszközböngészők egymáshoz kapcsolása egy vagy több eszközfüggetlen paraméter segítségével jöhet létre. Az összekapcsolás során a potenciális eszközböngészők körének szúkítéséhez az alábbi szabályok is felhasználhatóak:

- a látogatók valószínúleg nem rendelkeznek több vezetékes internetkapcsolattal

- a felhasználók helyváltoztatásának korlátossága

- a nem mobil eszközök esetében a munkamenetek alatt a felhasználó földrajzi pozíciója nem változik

Az alábbiakban az összekapcsolásra alkalmas paramétereket veszem sorra és kiértékelem:

- rövid időintervallumon belül egyazon IP cím használata/azonos hálózat használata:

○ egy látogató egy adott hálózatból több eszközböngészőt is használhat, jó példa erre az az eset, amikor a felhasználó a laptopját és a mobiltelefonját is használja az otthoni hálózatból

○ az otthoni internet előfizetéssel igen gyakran 1 db IPv4-es IP címmel több eszköz is képes elérni a hálózatot a NAT/PAT technológiának köszönhetően

- nem mobil eszközök esetében azonos földrajzi pozíciónál

○ vezetékes kapcsolódás esetén a pozíció meghatározás nem pontos, csak város szintú feloldást eredményez, így az ott megállapítottak alkalmazhatóak erre az esetre is

○ vezetéknélküli kapcsolódás esetén pozíciót lekérdezni (A-GPS, GPS, GLONASS, Wifi) képes eszközzel felszerelt egységgel rendelkező hardver esetén, az IP címből visszafejtve a pontosság kérdéses lehet, ennek mértékétől függően a közel ugyanabból a pozícióból érkező lekérdezések szintén potenciális alternatív eszközböngészőt jelenthetnek

- felhasználó jellemzői alapján

○ billentyúzet, egér, tapipad és érintőképernyó használat: az internet eléréséhez használt fejlett beviteli eszközök vezérlése a látogatóra jellemző, akárcsak az aláírás. Ez a biometrikus azonosítás egyik fajtája, a viselkedés szerinti azonosítási módszerek közé tartozik. A módszer 
nem biztosítja ugyanazt a szintet, mint pl. egy retina szkennelés, viszont a használatához nem szükséges drága hardvert beszerezni. A módszer azon alapszik, hogy az egyének gépelési stílusa egyedi. A billentyưzetfigyelés során olyan alapvető tulajdonságokat mérnek, mint a sebesség, a lenyomás ereje és a nyomvatartás ideje. Az azonosításhoz csupán egy 300 karakterből álló mintára van szükség, amiből kinyerhető az egyénre jellemző információ és a későbbiekben referenciaként használható. A módszer az esetek 96\%-ban múködött helyesen. (Peter, David, David, Warren, \& Jonathan, 2005) Míg az egérmozgást követő kísérletek esetében 20 kattintás elegendő volt ahhoz, hogy az algoritmus csak 1,3\%-ban tévedjen. (Shivani, 2004) (Nan, Aaron, \& Haining) A billentyúzet és egérmozgás figyelése (akár a telepített betútípusok listájának lekérdezése is) azonban az egérmozgás során rengeteg adat keletkezik, mivel a minél nagyobb a minta, annál pontosabb lesz az elemzés. Az adatokat célszerú tömörített formában átküldeni a szerveroldalra és a már meglévő minták között hasonlóakat keresni.

○ hasonló weboldalak meglátogatása: a látogató által meglátogatott weblapok halmaza az egyénre jellemzó, így ez alapján be lehet azonosítani a felhasználót és ezzel a különböző eszközböngészőket egymáshoz lehet kapcsolni

Fontos kiemelni, hogy a felhasználó és a jellemzők összekapcsolása feltételes. Ha egy esemény többször is bekövetkezik, akkor annak a valószínúsége, hogy a két eszközböngésző egy személyhez köthető megnő. (pl: ha minden hétköznap egy adott ISP-hez csatlakozva ugyanabból a hálózatból éri el egy személy az internetet mobiltelefonnal és laptop használatával) Célszerú a feltételezett alternatív eszközböngészőket elmenteni, majd ahogy idővel egyre több adat gyúlik össze a látogatóról felülvizsgálni annak elemeit.

\section{5. Összegzés}

A webes böngészési alapjainak bemutatását követően az internetezéshez használt eszköz szoftver és hardverkörnyezetét vettem górcső alá, majd az internetező személy online tanúsított viselkedését jellemző és hozzáférhető paramétereit 
vizsgáltam meg, amelyek felhasználásával a személye beazonosíthatóvá válhat. Tehát a téma megértéséhez szükséges ismeretek rendszerezett leírását követôen, megállapítottam a böngésző segítségével elérhető adatok lehetséges halmazát, majd ezen adatok elérésének módját és végül az egy domain alól elérhető weboldalak számára összegyújthető adatokból levezettem a látogatók követésének módszerét.

Az internetet használók több eszközt és azon több különböző eszközböngészőt is használhatnak. A látogató online viselkedésének átfogó elemzéséhez ezen eszközböngészők összekapcsolása szükséges. $\mathrm{Az}$ eszközböngészők összekapcsolhatóságának valószínúsége annál magasabb, minél szélesebb rálátásunk van a látogató online viselkedésére, cselekedeteire, időben és adatminőségben egyaránt.

Az üzlet szempontjából fontos jellemzők szerint csoportosított felhasználók számára küldött reklámok hatékonysága jóval magasabb, mint a hagyományos reklámoké. A cél határozza meg az azonosítás szintjét: Az üzlet számára nem fontos, hogy a látogató pontos kilétét ismerjük, az is elegendő, ha csak néhány kiemelt tulajdonságát ismerjük. Az ebben a fejezetben leírt technológiai modellek és technikák a következőkben ismertetett kutatásaim alapjául szolgáltak. 


\section{AZ ESZKÖZBÖNGÉSZŐKRŐL BEGYÛJTHETŐ ADATOK JELLEMZŐI}

Ebben a fejezetben leírom a kutatásaimhoz nélkülözhetetlen adatgyújtési fázist, valamint a rá épülő elsô kutatásomat, az egy domain alól elérhető weblapok látogatóinak eszközböngészőjéről begyưjthető adatokból kinyerhető információk elemzését mutatom be.

\subsection{A kutatás bemutatása}

A látogatók több különböző eszközt használnak internetezésre (pl: mobiltelefon, tablet vagy laptop) melyekről a tartalomfogyasztási és eszközhasználati szokásaik nagymértékben eltérhetnek. A látogatók online szokásainak teljes felméréséhez, nem elég egy eszközről gyújtött adatok elemzése, hanem szükséges a különböző eszközök és böngészők összekapcsolása is.

Amíg a látogató internetezésre használt eszközének paramétereinek lekérdezése egyszerú, maguknak a látogatók beazonosítása már nem triviális. Kutatásomban annak járok utána, hogy miként használható fel a látogató által használt böngészők és eszközökről lekérdezhető adatok a látogató azonosítására. Utánajárok, hogy milyen látogatóra jellemző adatok - például a billentyưzet és egérhasználat kérdezhető le a böngésző segítségével és ezek milyen mértékben alkalmasak a látogató azonosítására. Elemzem, hogy a látogató eszközböngészőjéből hozzáférhetô adatok milyen mértékben járulnak hozzá a látogató beazonosításához.

Egy oldalletöltés alkalmával néhány kilobyte-nyi adat hozzáférhető a meglátogatott webhely számára, feltételezésem szerint ebből adatbányászati módszerekkel értékes - akár személyiségi jogokat sértő - információk nyerhetőek ki.

\subsection{Az adatgyújjtés}

Az adatgyújtési fázisban a dolgozatban a 3 kutatási célhoz szükséges minta begyưjitésének folyamatát és tervezésének lépéseit írom le. A megfelelő minőségú minta biztosításához az alábbi pontokban fogalmaztam meg az adatgyújtô alkalmazás tulajdonságait:

- a hozzáférhető adatok legszélesebb körét képes legyen elmenteni

- alacsony szintú hozzáférést biztosítson az összegyújtött adatokhoz 
- az ismert blokkoló alkalmazások (Ghostery stb.) ne legyenek képesek megakadályozni a múködését

- adatgyújtő alkalmazás múködése közben az átlagos felhasználó látogató ne tudja, hogy adatait kezelem

Megvizsgáltam az interneten közzétett adatgyűjtő alkalmazásokat, azonban nem találtam olyat, amely az általam felállított feltételek mindegyikét kielégítette volna. Emiatt saját alkalmazás fejlesztése mellett döntöttem.

A fejlesztés megkezdése előtt számba vettem a felhasználó azonosításának módszereit, amelyeket alapvetően két csoportba lehet elkülöníteni:

- A látogató a saját adatai önkéntes megadásával engedi saját magát azonosítani és emiatt követni

- A látogató pusztán az internetezéshez használt hardver és szoftverkörnyezetének, valamint a saját viselkedésének jellemzőivel teszi lehetővé saját maga azonosítását. Az egyén az érdeklődési körének megfelelő weboldalakat látogatja meg, így a meglátogatott weblapok listájából következtetni lehet a látogató személyére (Jia-Ching, Chu-Yu, \& Vincent, 2012)

Amennyiben a látogatók egyedi azonosító adataik megadásával felfedik magukat, online beazonosításuk triviálissá válik, emiatt a kutatásom célpontjai a második kategóriába eső látogatók csoportja volt.

A már korábban definiált adatgyưjtő weblaptípus kategóriák szerint a saját fejlesztésû adatgyújtő alkalmazásom az egyszerû weblapok/adatgyújtők csoportjába tartozik, amellyel a látogatók online viselkedési jellemzőinek kis szelete érhető el, míg a kiterjedt hálózattal rendelkező weblapok a felhasználó online viselkedéséről átfogó képet kaphatnak.

A lementett adatokat időbeliségük szerint az alábbiak szerint lehet elemezni:

- a lementett rekordok elemzése: egy elmentett rekord a látogató böngészésének egy időpillanatát rögzíti

○ a pillanatfelvételek elemzésével az oldal látogatóinak összességéről is nyerhető információ 
- eszközböngészőhöz tartozó munkamenetek elemzése: az eszközböngészők számára kiosztott egyedi azonosítók biztosítják az eszközböngészőről megkezdett munkamenetek elemzését

○ lehetőség nyílik a látogató eszközböngészője paramétereinek időbeli vizsgálatára

○ mobil eszköz esetén a látogató által meglátogatott helyek kideríthetóek lehetnek

○ a meglátogatott weblap bejárásának módja elemezhetôvé válik

- az egy látogató által használt összekapcsolt eszközböngészőkön átívelő elemzési módszer használatával: a látogató által használt valamennyi online viselkedési variáció megismerhető

○ elérhetővé válnak a látogató által használt eszközböngészők munkamenetei

A kutatásom során az egy oldalba beépített adatgyújtő alkalmazásom pusztán a mindenki számára hozzáférhető adatokra támaszkodik, az elemzési fázisban külön elemeztem a rekordokat és a látogatók munkameneteit.

A felhasználó azonosítása az internetezésre használt eszköz és böngésző paramétereinek azonosításával, illetve a felhasználó eszközhasználati módjának azonosításával lehetséges.

A böngésző és az internetezésre használt eszköz hardver és szoftver paramétereinek lekérdezésével magát az eszközt lehet azonosítani. A paraméterek többsége rendelkezésre áll, pusztán csak ki kell olvasni a kliens vagy a szerveroldalon. A közvetlenül nem hozzáférhető többi adatot vagy egy harmadik féltől lehet lekérdezni vagy valamilyen kiegészítő eszköz segítségével érhetőek el.

Az eszköz használatának módja jellemző a felhasználóra. Az eszköz használatának módját egyrészt az input eszközökön keresztül lehet detektálni. Ez jellemzően az egér vagy az érintőképernyő, amelynek a használata az aláíráshoz hasonlóan az egyénre jellemző, hiszen ugyanolyan finom motorikus mozgások szükségesek hozzá. Szintén jellemző lehet az egyénre az általa meglátogatott weboldalak köre vagy az érdeklődési körébe tartozó weboldalak megtekintése. 


\subsubsection{A célcsoport}

A kutatás tervezésekor a célom az volt, hogy a lehető legtöbb felhasználót érjem el. Az BCE e-learning rendszerének használata ebből a szempontból ideális, mivel ezzel azt a hallgatók közel fele elérhető.

Az Egyetem e-learning rendszerébe illesztett adatgyưjtő alkalmazást csak a rendszer felhasználói érhetik el. Belépni csak a felhasználói azonosítóval és jelszóval lehetséges. Minden látogató csak ahhoz a kurzushoz férhet hozzá, amihez hozzárendelte a kurzus adminisztrátora. A belépésre jogosultak a BCE hallgatói, tanárai és kisebb számban az e-learning rendszer karbantartói. A megfigyelési egységek az egyének. A diákok túlnyomórészt az X és a Y generáció tagjai:

- X generáció tagjai 1960 és 1980 között születettek. Jellemzőik a megbízhatóság, elmélyült szakmai igényesség, magas motiváció, kooperativitás és karrierizmus. A digitális technológiával már fiatalon megismerkedtek, de a következó generációkhoz képest ezen a területen alulmaradnak.

- Y generáció tagjai 1980 és 2000 között születtek, főbb jellemzőik közé tartozik az elmélyült tudás iránti igény és a munkára, tanulásra való motiváltság gyengülése (Regina, 2012)

A kutatás végeztével a kapott adathalmaz sem a magyar populációra, sem az egyetemi hallgatókra nézve nem tekinthető reprezentatívnak.

\subsubsection{Az adatgyújtó alkalmazás}

A Budapesti Corvinus Egyetem e-learning rendszerébe beépített, általam fejlesztett alkalmazás 2012. május 3 és 2012. május 22 között gyűjtötte a látogatók adatait. Az alkalmazás múködésének leírása megtalálható a „Adatgyújtő alkalmazás fejezetben".

Mivel a kutatás során személyes adatokat is kezelek, ezért indulás előtt az alkalmazást auditálásnak kellett alávetnem, valamint meg kellett szereznem az intézeti adatvédelmi biztos engedélyét és az e-Learning és Oktató- és Szolgáltató Központ vezetőjének hozzájárulását az alkalmazásom az e-learning rendszerbe való beépítéséhez. A kutatás tervezésénél a kérvények és engedélyek beszerzése hozzávetőlegesen 3 hetet vett igénybe. 
Az alkalmazás elkészültét követően annak teljes forráskódját el kellett küldenem az Intézeti Adatvédelmi felelős által kijelölt bizottságnak felülvizsgálatra. Ezt követôen történhetett meg az alkalmazás beépítése.

A tesztelési fázis alatt az alkalmazást különböző böngészőkben, más és más operációs rendszerek alól, valamint különböző eszközökkel (számítógép, táblagép, mobiltelefon, okostelefon) teszteltem, hogy megbizonyosodjak, az a legtöbb esetben az elvártaknak megfelelően múködik. A tesztfázis sok különféle hiba kiszúrésére alkalmas. (pl: mindenféle eszközön jól olvashatónak kell lennie a szövegeknek vagy a mobiltelefon kijelzője túl kicsi a többsoros szöveg megjelenítéséhez)

Az adatgyújtő alkalmazás egyik fontos lépése volt a kinyerhető adatok relevanciájának és annak meghatározása, hogy az adatgyújtés mekkora terhet ró a kliens és a szerveroldalra, hogy elkerüljem a felesleges adatok mentését. A becslés alapján adatbázist hoztam létre az adatok tárolására.

Az adatok kinyeréséhez szükséges hardver erőforrás azt mutatja, hogy a paraméterhez való hozzáférés vagy az adott paraméter kinyerése milyen mértékben terheli a kliens és/vagy a szerver eróforrásait és mennyit kell várni a kinyerni kívánt adatra:

- alacsony: alacsony mértékben terheli a hardvert egy érték kiolvasása vagy környezeti változóhoz való hozzáférés

- közepes: pl. egy script futtatása, amely képes felmérni a böngésző képességét, vagy egy DNS lekérdezés

- magas: pl. online API-tól való lekérdezés vagy a processzort erôsen terhelő múvelet

- nagyon magas: komoly statisztikai és adatbányászati múveletek esetén

Az adatok relevanciája azt jelenti, hogy azok milyen mértékben járulnak hozzá a látogató beazonosításához és követhetőségéhez:

- alacsony: kismértékben járulnak hozzá a felhasználó eszközböngészőjének követéséhez, a paraméterek értéke nagy valószínúséggel nem egyedik. Pl. nagyon sok böngésző támogatja a localStorage-et, azonban az összes HTML5ös jellemző egyedi lehet

- közepes: 4-8 csoportra osztja a látogatókat, ezzel csökkenti a látogató kilétére vonatkozó bizonytalanságot 
- magas: a tényező ismerete nagyban hozzájárul a felhasználó azonosításához, nagy valószínúséggel jellemzi az eszközböngészőt. Hátránya lehet, hogy viszonylag rövid időn belül változhat.

A változók részletes listája és az értékelésük teljes listája megtekinthető a 8.7.2 fejezetben. Néhány fontosabb megfigyelés:

- A HTML5 képességek böngészőre és azok verzióira jellemzőek, így azokat felesleges detektálni és lementeni.

- Az egérmozgás követése és leütött billentyúk elmentése nagyon leterhelheti a kliens oldalt és a hálózatot. A felhasználói élmény romlásától tartva, nem fejlesztettem bele az adatgyújtő alkalmazásba.

- A localStorage kliens oldali adattároló technológia megbízhatóbb, mint a sütiben történő adattárolás. Így, ha a süti tartalma valamiért elvész vagy megsérül, az eszközböngésző azonosító a localStorage-ből még visszaállítható.

- Az inkognitó mód detektálására már nincs lehetőség, mert a hibát, amely révén hozzáférhető volt ez az információ a böngészők fejlesztői már kijavították.

\subsubsection{A lementett adatok}

Az alkalmazás által lementett adatok teljes listája a függelék 8.7.3 fejezetében tekinthető meg. Az adatgyújtési időszak után következett az adatok előfeldolgozása az alábbiak figyelembevételével:

- A fizikailag a Corvinus Egyetemen található számítógépeket kivettem az elemzési mintából, mivel az ott található számítógépekről minden belépés alkalmával letörlődnek a sütik és szoftver és hardver kiépítettségük is hasonló.

- Az IP címből kinyerhető az internet szolgáltató vagy az internetezéshez használt intézmény neve, melynek értékét elmentettem a host mezőbe

- Azoknál a rekordoknál, ahol a látogatók nem adták hozzájárulásukat a földrajzi hely megosztásához, az IP címeket leképeztem hosszúsági és szélességi fokokká

- A Google Map API-jának segítségével a földrajzi pozíciókat városra, utcára és házszámra oldottam fel a 14. ábra: a földrajzi pozíciók város, utca és házszámra történó feloldása Pentaho-val Google Maps API-n keresztül látható módon 


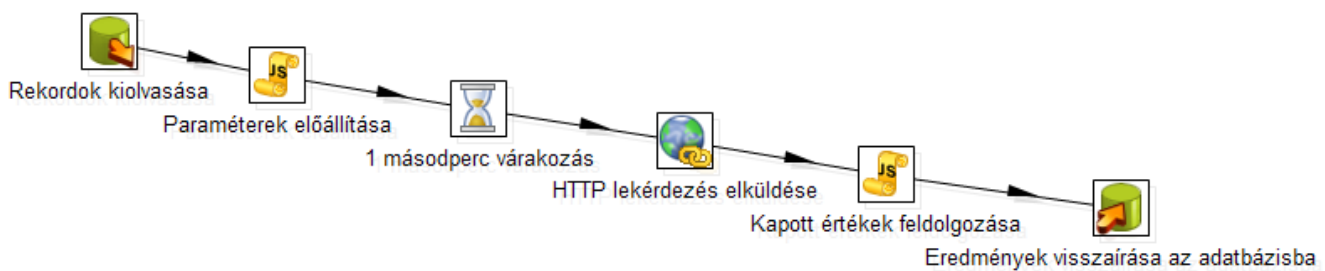

14. ábra: a földrajzi pozíciók város, utca és házszámra történó feloldása Pentaho-val Google Maps API-n keresztïl

- Az adattábla referrer mezőjének értéke alapján kinyertem, hogy a látogató mely tantárgyhoz tartozó oldalt töltötte be

- A mobil eszközökön található operációs rendszert kézzel vittem fel az adatbázisba

- A böngésző típusát (browserFamily), az operációs rendszer típusát (osFamily) és verzióját (osVersion), valamint az eszköz (device) mezók értékét az UAParser PHP könyvtár segítségével a HTTPUserAgent mező értékéből kinyerve töltöttem ki

\subsection{A bizonytalanság-csökkentő képesség mérőszáma}

A dolgozatomban a látogatók által használt eszközböngészőkből kinyert adatok bizonytalanság-csökkentő képességének méréséhez Athanasios S. Voulodimos \& Charalampos Z. Patrikakis által a „Quantifying privacy in terms of entropy for context aware services". (Voulodimos \& Patrikakis , 2009) címú cikkében közzétett keretrendszert, valamint a Peter Eckersley „A Primer on Information Theory and Privacy" (Eckersley, 2013) cikkében közzétett technikákat használom Az általuk használt keretrendszer Claude E. Shannon által 1949-ben publikált bizonytalanság számszerúsítésének matematikai módszerén alapszik. A bizonytalanság fokát Shannon entrópiában (S) fejezi ki. (Shannon, 1948) Egy X rendszer információ entrópiájának képlete:

$$
S(X)=-K \sum_{j=1}^{M} p_{j} \log \left(p_{j}\right)
$$

Ahol: 
- K különböző mértékegységek összehasonlításához használt konstans (dolgozatomban az értékét $\mathrm{K}$ = 1-nek választom)

- M a vizsgált rendszer alrendszereinek értékeinek/állapotainak számossága

- $\quad \boldsymbol{p}_{j}$ a j-edik elem kiválasztásának valószínúsége $\left(\operatorname{ahol} \sum_{j=1}^{M} p_{j}=1\right)$

Megjegyzem, hogy az informatikai adatok entrópiájának mérésére kettes alapú logaritmust használok, tehát a képletekben szereplő logaritmus függvény minden esetben kettes alapú $\left(\log =\log _{2}\right)$. A képlet csak az alábbi feltételezések és megkötések mellett használható:

- A látogatót jellemző paraméterek azonos valószínúséggel vehetik fel az értékeiket (monotonitás)

- Egy alrendszerekból álló rendszer entrópiája a diszjunkt alrendszerek ${ }^{20}$ entrópiájának súlyozott összege. Tegyük fel, hogy $\mathrm{S}_{\mathrm{c}}$ a következő elkülönülő alrendszerekből áll: $\mathrm{S}_{\mathrm{a}}$ és $\mathrm{S}_{\mathrm{b}}\left(\mathrm{a}=\left|S_{a}\right| /\left|S_{c}\right|\right.$ és $\left.\mathrm{b}=\left|S_{b}\right| /\left|S_{c}\right|\right)$, ekkor $\mathrm{H}\left(\mathrm{S}_{\mathrm{c}}\right)=\mathrm{H}(\mathrm{a}$, b) $+\mathrm{aH}\left(\mathrm{S}_{\mathrm{a}}\right)+\mathrm{bH}\left(\mathrm{S}_{\mathrm{b}}\right)$ a rendszer entrópiája. (Voulodimos \& Patrikakis , 2009) (rekurzivitás)

Az előbbiekben megismertetett entrópia modell használható a látogatókról összegyűjtött adatok minőségi jellemzésére, használatával összehasonlíthatóvá válnak a mintában szereplő változók információfelfedési képességei.

\subsection{Az összegyứjtött adatok vizsgálata}

A kutatásom exploratív, azaz feltáró jellegű, hipotéziseket nem definiáltam, ehelyett az alábbi, a kutatás irányát meghatározó kérdéseket és kérdésköröket fogalmaztam meg:

- Az eszközböngészőkből származó adatok segítségével, személyes adataik felhasználása nélkül lehetséges-e a látogatók beazonosítása és követése?

○ Milyen adatok vagy az adatok mely csoportja járul hozzá hatékonyan a felhasználók azonosításához és követéséhez a látogató által használt eszközökön keresztül?

\footnotetext{
${ }^{20}$ Egy rendszer alrendszereiben lévő elemek között nincs olyan, amely valamely más alrendszerébe is beleillik. A csoportosítás alapját képező tulajdonságok vagy tulajdonságok csoportja egyértelmúen képes eldönteni a vizsgálandó elem alrendszerbeli tagságát.
} 
- Egy weboldal megtekintésével elérhető-e elegendő mennyiségú adat a látogató személyéről vagy környezetéről ahhoz, hogy a személyes adatai nélkül azonosítani és követni lehessen?

○ Átlagosan milyen mennyiségú adat érhető el egy látogatóról egy weboldal megtekintése során?

○ Milyen módszerekkel lehetséges mérsékelni a weblapok számára elérhető adatokat?

- A látogatóról megszerzett adatok milyen mértékben járulnak hozzá az azonosításához?

○ A hozzáférhető paraméterek milyen mértékben képesek eloszlatni a látogató beazonosításának bizonytalanságát?

\subsubsection{Alapvető statisztikák}

A kutatás adatgyújtési fázisát követően az alábbi statisztikákat szereztem be. A Moodle-re vonatkozó adatokat a rendszerbe ágyazott Google Analytics-ből nyertem ki, amelyet a Moodle karbantartóitól az e-Learning Oktató- és Szolgáltatóközpont munkatársaitól kértem el.

- Látogatási statisztikák

○ 2013. március havi oldalletöltés: kb. 134000

○ 2013. március havi egyéni látogató: kb. 31000

- Moodle-ből nyert adatok:

○ 8169 különböző felhasználó lépett be az elmúlt hónapban

○ 8542 különböző felhasználó lépett be az elmúlt félévben

- Corvinus weblapról nyert információ ${ }^{21}$

○ hallgatói létszám: 17879

○ tanárok létszáma: 867

Az adatgyújtési fázisban 647242 rekordot mentett el az alkalmazás az adatbázisba, amelyek jellemzői a 8.7.4 fejezetben tekinthetőek meg. Az egyes mezők értelmezése rendre:

- lementett paraméter neve

\footnotetext{
${ }^{21} \mathrm{http} / /$ web.uni-corvinus.hu/subpage_choice_control.php?org=2\&id=8\&UC=\&subpage=\&LNG=eng
} 
- kitöltött érték: azon rekordok száma, amelyekben a kérdéses paraméter ki volt töltve (a kliens vagy a szerver oldalon a paraméter elérhetố volt, az lementésre került az adattábla megfelelő oszlopába), zárójelben mögötte a százalékos érték található

- különböző értékek: ahány különböző rekord található az adatbázisban az adott paraméterre nézve

- különböző értékek a kiosztott eszközböngészők arányában: az aktuális paraméter és a kiosztott felhasználói azonosító számának hányadosa.

A táblázat fejléc alatti elsô sorában látható, hogy a két hét alatt 32529 darab eszközböngésző azonosítót osztott ki az alkalmazás, ha ezt az értéket elosztjuk a belépett felhasználók számával, akkor minden egyes felhasználóra $\mathbf{3 , 9 8}$ eszközböngésző azonosító jut, tehát minden egyes felhasználó majdnem 4 különböző eszközböngészővel lépett be. Ez az érték ugyan kevesebb, mint a Cisco felmérésében szereplő érték, azonban esetemben a minta a Corvinus Egyetem polgárai, ez torzított sokaság. A felhasználók jelentős része feltehetőleg legalább egyszer használta a tantermi gépeket, melyek közös jellemzője, hogy fix IP-vel rendelkeznek, valamint közel hasonló kiépítettségúek, így a lementett paraméterek alapján nehéz különbséget találni köztük.

A lementett adatok jellemzőinek listája a 8.7.4 fejezetben tekinthetó meg. Néhány fontosabb paraméter és értelmezése az alábbiakban olvasható:

- A mintában 2173 különböző HTTP user agent található, ez a kiosztott eszközböngészők 6,68\%-a

- A telepített betútípusok listájának lekérdezése az esetek 95,68\%-ban elérhető volt.

Az alábbi paraméterekkel lehetséges az eszközböngészők legalább 5\%-át beazonosítani:

- IP cím: az esetek nagy részében csak a munkamenet ideje alatt képes azonosítani az eszközböngészőt

- HTTP user agent: a böngészőról, az operációs rendszerrôl és a böngészéshez használt eszköz egy szövegbe való sűrítése

- URL: a felhasználó által megtekintett weblapok 
- Telepített betútípusok: közel 50\%-os eredményt lehet elérni a telepített betűtípusok listájának lekérdezésével

A válaszok keresése közben arra a megállapításra jutottam, hogy pusztán az eszközböngészőkből származó adatokból a lementett mintámban nem tudok kimutatni kapcsolatot a személyhez nem köthető adatok és a látogatók személyes adatai között, a magukat szándékosan felfedni nem kívánó látogatók esetében. Ennek a kutatásnak a részleteit a dolgozatomban nem tartalmazza.

A fenti ok miatt a böngésző́k számára hozzáférhető paraméterek bizonytalanság-csökkentó erejét vizsgáltam, bemutatva az egy domain alól elérhető weboldalak és a közösségi oldalak látogatóikról elérhető adatok mennyiségét és minőségét.

\subsubsection{A lementett változók bizonytalanság csökkentö ereje}

A kutatás első lépéseként az elemzendő változókat fa struktúrába rendeztem majd külön-külön határoztam meg a bizonytalanság csökkentő erejüket. Az ábra megtekinthetô a függelék 8.7.3 fejezetében. A számolás eredménye a 15. táblázatban látható. 


\begin{tabular}{|c|c|c|c|}
\hline Paraméter & $\begin{array}{c}\text { Lementett } \\
\text { értékek száma }\end{array}$ & $\begin{array}{c}\text { Egyedi } \\
\text { elemek } \\
\text { száma }\end{array}$ & $\begin{array}{c}\text { Bizonytalanság } \\
\text { csökkentő } \\
\text { tényezó }(\Delta S) \\
\text { (bit) }\end{array}$ \\
\hline Facebook azonosító & 169 & 139 & 0,28 \\
\hline IP cím & 32529 & 14443 & 1,17 \\
\hline DNT & 32529 & 2 & 13,98 \\
\hline $\begin{array}{l}\text { Képernyó szélessége és } \\
\text { magassága }\end{array}$ & 32529 & 509 & 5,99 \\
\hline HTTP User Agent & 32529 & 2078 & 3,96 \\
\hline Böngésző típusa & 32529 & 7 & 12,18 \\
\hline Böngésző típusa és verziója & & 243 & 7,06 \\
\hline Operációs rendszer & 32529 & 27 & 10,23 \\
\hline $\begin{array}{l}\text { Operációs rendszer típusa és } \\
\text { verziója }\end{array}$ & 32529 & 101 & 8,33 \\
\hline Flash blokkolt-e & 32529 & 2 & 13,98 \\
\hline Flash verzió & 32529 & 104 & 8,28 \\
\hline Silverlight & 32529 & 26 & 10,28 \\
\hline Quicktime & 32529 & 39 & 9,70 \\
\hline Java & 32529 & 49 & 9,37 \\
\hline PDF Reader & 32529 & 2 & 13,98 \\
\hline Adobe Reader & 32529 & 90 & 8,49 \\
\hline Kapcsolat típusa & 32529 & 4 & 12,98 \\
\hline $\begin{array}{l}\text { Földrajzi pozíció (IP címből } \\
\text { visszafejtett) }\end{array}$ & 32527 & 180 & 7,49 \\
\hline GeoLocation & 236 & 155 & 0,60 \\
\hline Telepített betútípusok & 32529 & 8356 & 1,96 \\
\hline
\end{tabular}

15. táblázat: Lementett változók bizonytalanság csökkentó ereje

Összesen 32529 darab kiosztott eszközböngésző azonosító alapján a mintában az egyes eszközböngészők azonosításához $\Delta S=-\log _{2} 1 / 32529=13,81 \approx 14$ bit szükséges.

A Facebook azonosító esetében a $\Delta \mathrm{S}=0$, hiszen ha elérhetô, akkor az adott eszközböngészőt használó felhasználót egyértelmúen azonosítja. Tehát ha a $\Delta \mathrm{S}$-vel jelölt entrópia csökkentő tényező nullához közeli szám, akkor az jó bizonytalanság csökkentő erővel bír. A táblázatban szereplő nullánál nagyobb érték $(0,28)$ azzal magyarázható, hogy néhány látogató több alkalommal is engedélyezte az adatgyújtő alkalmazás számára az adataihoz való hozzáférést.

Amíg a rengeteg egyedi elemmel rendelkező telepített betútípusok $\Delta \mathrm{S}$ értéke nullához közeli, addig a mindössze 2 értéket felvevő jellemzők esetében (DNT, Flash 
blokkoló jelenléte vagy a telepített PDF olvasó) értéke igen magas, hiszen ezen változó bizonytalanságcsökkentő ereje gyenge.

Ezt követően a paraméterek csoportjának bizonytalanság csökkentő erejét teszteltem. A kapott eredményeket az alábbi táblázatban foglaltam össze:

\begin{tabular}{|c|c|c|c|}
\hline Paraméter & $\begin{array}{c}\text { Lementett } \\
\text { értékek száma }\end{array}$ & $\begin{array}{l}\text { Egyedi } \\
\text { elemek } \\
\text { száma }\end{array}$ & $\begin{array}{c}\text { Bizonytalanság } \\
\text { csökkentő } \\
\text { tényezo }(\Delta S) \\
\text { (bit) }\end{array}$ \\
\hline $\begin{array}{l}\text { Böngésző környezetének } \\
\text { jellemzői }^{22}\end{array}$ & 32529 & 3141 & 3,37 \\
\hline $\begin{array}{l}\text { Szoftver és hardver környezet } \\
\text { jellemzői }^{23}\end{array}$ & 32529 & 10560 & 1,62 \\
\hline $\begin{array}{l}\text { Hardver környezet és a } \\
\text { böngészó jellemzóoi }{ }^{24}\end{array}$ & 32529 & 14594 & 1,15 \\
\hline $\begin{array}{l}\text { Egy átlagos munkamenet ideje } \\
\text { alatt állandó paraméterek }{ }^{25}\end{array}$ & 32529 & 17845 & 0,86 \\
\hline
\end{tabular}

16. táblázat: Lementett változók bizonytalanság csökkentő ereje

A táblázatból látható, ahogy egyre több releváns paramétert veszünk be, az egyedi elemek száma nő.

\section{5. Összegzés}

Az internet elképesztő fejlődésének köszönhetôen nemcsak új iparágak jöttek létre, hanem a már létezők további fejlődésére is jótékony hatással van. Ezek egyik nyertese a marketing. Az online reklámok hatékonysága jóval magasabb, mint a hagyományos reklámoké, mivel az online hirdetésekkel pontosabban érhetőek el a célcsoportok.

Ha az online kereskedelemben részt vevő cégek többet tudnak a vásárlóik ízlésérôl, az igényeikhez jobban igazodó célzott reklámokat küldhetnek számukra. (Escobido \& Gillian, 2013) Ezt az információt a nyílt internetről nem minden esetben lehetséges összegyújteni, ha mégis, akkor az igen költséges. Az effajta személyes

\footnotetext{
${ }^{22}$ HTTP UserAgent, HTTP Accept, HTTP Accept Encoding, HTTP Accept Language, HTTP Accept Charset, DNT, böngésző típusa és verziója, földrajzi pozíció

${ }^{23}$ Képernyő méretei, operációs rendszer, érintőképernyő, kapcsolódás típusa, telepített betűkészletek

${ }^{24}$ HTTP UserAgent, HTTP Accept, HTTP Accept Encoding, HTTP Accept Language, HTTP Accept Charset, DNT, böngésző típusa és verziója, képernyő mérete, operációs rendszer típusa és verziója, földrajzi pozíció, érintőképernyő, kapcsolódás típusa, telepített betúkészletek

${ }^{25}$ Képernyő mérete, HTTP UserAgent, HTTP Accept, HTTP Accept Encoding, HTTP Accept Language, HTTP Accept Charset, DNT, böngésző típusa és verziója, operációs rendszer típusa, földrajzi pozíció, érintőképenyő, Flash, a Flash blokkolt-e, Quicktime, Java, PDF olvasó, Acrobat Reader verziószáma, telepített betû́készletek
} 
jellemzők a látogatók az online világban nyújtott viselkedéséből következtethetőek ki. (Kosinksi, Stillwell, \& Graepel, 2013)

Érdekes ellentétek figyelhetôk meg az emberek online viselkedésével kapcsolatban. A felhasználók féltik a személyes adataikat és mindenképpen szeretnék elkerülni azok kompromittálódását, még akkor is, ha azt a felhőben tárolják. Ezzel ellentétes az a folyamat, hogy a népszerú közösségi hálózatokon az emberek gyakorlatilag ellenszolgáltatás nélkül kiteregetik akár a legbelsőbb titkaikat is. Felmerülhet a kérdés, hogy hogyan várhatja el valaki, hogy a felhőbe feltöltött adatai biztonságban legyenek, ha az alapvető biztonsági ajánlásokat sem tartja be és esetleg más fórumokon tálcán kínálja a búnözők számára az adataihoz való hozzáférés lehetőségét. A webes böngészéssel rengeteg adat elérhető a böngésző személyéről, az általa használt eszközökről szokásairól más egyéb személyes tulajdonságairól, amelyek alapján a látogatók profilozhatóvá válnak.

A feltáró jellegú kutatásom célja annak bemutatása, hogy az egy domain alól elérhető weboldalak számára a látogatók által használt böngészők és eszközökről elérhető adatok használhatóak-e a látogató azonosítására és követésére. A kutatásomban elemeztem, hogy a látogató eszközböngészőjéből hozzáférhető adatok milyen mértékben járulnak hozzá ehhez.

Egy oldalletöltés alkalmával akár néhány száz kilobyte-nyi adat hozzáférhető a meglátogatott webhely számára, amelyből adatbányászati módszerekkel értékes akár személyhez köthető - információk nyerhetőek ki, valamint ezen adatok segítségével lehetséges az egyének beazonosítása és követése, személyes adataik felhasználása nélkül. A rendelkezésre álló paramétereket a következő négy csoportba rendeztem: a böngésző környezetének jellemzői, a szoftver és hardver környezet jellemzői, a hardver környezet és a böngésző jellemzőit és az egy átlagos munkamenet ideje alatt állandó paramétereket. A kutatás eredményeképpen azt tapasztaltam, hogy minél több változót használok a felhasználó azonosításához, annál nagyobb vizsgálatba bevont változók együttes bizonytalanság eloszlató képessége. Ez azt jelenti, hogy egy ismert sokaság elemei közül nagy bizonyossággal be tudjuk azonosítani az egyén által használt eszközböngészőt, feltéve, hogy a munkamenet ideje alatt állandó paraméterei ismertek. Ebből az is következik, hogy amennyiben meg szeretnénk nehezíteni a követőink dolgát, célszerú proxy-n keresztül minél kevesebb paramétert megosztani a követő weboldalak és harmadik felek számára. 


\section{AZ EGYETEMI POLGÁROK PSZICHOLÓGIAI JELLEMZŐI ADATVÉDELMI SZEMPONTBÓL}

Az Egyetemi polgárok pszichológiai jellemzőinek vizsgálata során a Budapesti Corvinus Egyetem polgárainak a legnagyobb közösségi oldal (Facebook) által összegyújtött, kinyilvánított preferenciákból kinyert személyes tulajdonságait elemzem. A kutatás keretében megismerhető, hogy a felhasználók által önként szolgáltatott adatokból miként lehetséges személyes jellemzőket kinyerni, megismerhető az Egyetemi polgárok személyes adatainak megosztási hajlandósága, valamint bemutatja a hozzáférhető személyes adatok sokaságát. Az egyéneket a személyes tulajdonságaik alapján klaszterekbe rendeztem, majd az eredményeimet összehasonlítottam a myPersonality Project kutatásának adatgyüjtési fázisának eredményeképpen létrejött mintából képzett klaszterekkel.

A University of Cambridge Psychometrics Center kutatói az online profilozás mérföldkövét tették le 2012-ben, amikor 58000 olyan önkéntes Facebook felhasználóval pszichológiai teszteket töltettek ki, majd ezt követően elemezték a látogatók Facebook-on található személyes adataikat is. Az elemzések eredményeinek egybevetését követően fejlesztettek egy mindenki számára elérhető API-t, amely a Facebook-os like-ok alapján képes meghatározni a vizsgálat alanyának pszichológiai jellemzőit. (Kosinksi, Stillwell, \& Graepel, 2013)

2015. januárjában publikálták egy újabb kutatásuk eredményét, amely szerint a számítógépes személyiségelemzésnél jóval pontosabb eredményt képes elérni, mint a hús-vér emberek, mivel a számítógép számítási képessége mára jelentősen felülmúlja az emberekét, valamint mentes az előítéletektől és kevesebbet is hibázik. A kutatás során 86000 emberrel töltettek ki egy 100 kérdésből álló személyiségtesztet, amely alapján képesek voltak lemérni a résztvevők 5 fő személyiségi jegyét (Big 5). A Big 5 személyiségi jellemzők leírása az 5.2 A Big 5 - személyiségi jellemzők fejezetben olvasható. A kérdőívet kitöltők eredményét összevetették a Facebook-os aktivitásukkal és ennek eredményeképpen pontosabban tudták megjósolni az egyének pszichikai egészségét, politikai hovatartozást és tulajdonképpen az életük „eredményét”. Néhány esetben a módszer pontosabban írta le az egyént, mint ő saját maga. 
Az eredmények felhasználásával fejlesztettek egy alkalmazást a Facebook-ra, amelynek a „képességei” megdöbbentőek. A kutatócsapat által kitalált modell számára inputként csak 10 Facebook-os like-ra van szüksége, hogy pontosabban legyen képes felmérni az elemzendő személyiségi jegyeit, mint egy kolléga, 70 like-ra, hogy pontosabban, mint egy szobatárs, 150 like-ra, hogy jobban, mint egy családtag és pusztán 300 like-ra, hogy pontosabban egy házastársnál. (Youyou, Kosinki, \& Stillwell, 2015)

\subsection{A myPersonality Project}

A University of Cambridge kutatói a 2012-es kutatásuk adatgyújtési szakaszában lementett egyének jellemzőinek anonimizált adatait kutatók számára hozzáférhetővé tették. Így lehetségessé vált a saját kutatásom keretében gyűjtött adatokkal való összevetése.

A számítógépek megjelenésével lehetővé vált a nagy mennyiségú természetes nyelvi szövegek elemzése, amelyekből következtetni lehet az előbb említett alapvető emberi jellemvonásokra, a különböző helyzetekben valószínú reakcióra és viselkedésmintákra. (Poria, Gelbukh, Agarwal, Cambria, \& Howard, 2013) Szintén bizonyított a kapcsolat a különböző személyiségi jellemzőkkel bíró egyének online platformokon (Facebook) való megjelenése között. (Golbeck, Robles, \& Turner, Predicting personality with social media, 2011)

A myPersonality Project kutatást követően sok olyan publikáció született, amelyek a kutatás eredményeképpen megszületett Facebook Like - pszichológiai jellemző adatbázison alapult. A kutatások egy része valamilyen feltételezést igazolt:

- Marketing kutatások igazolták, hogy azon egyének, akik a magas nyitottság személyiségjegy értékkel rendelkeznek, innovátorok és sok esetben képesek másokat befolyásolni. (Kosinski, és mtsai., 2012)

- A Facebook's Gross National Happiness Index (Facebook Össznemzeti Boldogság Index - FGNH) egy számba súríti a Facebook-os üzenetekben lévő szavak pozitív vagy negatív töltetét. Kiderült, hogy egy a szám a nemzeti ünnepek környékén tetőzik és nyomasztó események vagy megemlékezések alkalmával csökken. (Stillwell D. , Kosinski, Rust, \& Wang, 2012)

A Projekt egy másik része pedig az online profilépítés témakörét boncolgatja: 
- Golbeck Jennifer, Robles Cristina és Turner Karen „Predicting personality with social media" címú cikkükben közöltek egy olyan metódust, amely képes megjósolni az egyén személyiségi jellemzőit a Facebook-on megjelenő publikus profilja alapján. A kutatások azt bizonyítják, hogy van kapcsolat az ember személyiségi jellemzői és online viselkedése között. (Golbeck, Robles, $\&$ Turner, Predicting personality with social media, 2011)

- A Michal Kosinski és társai által írt „Facebook and Privacy: The Balancing Act of Personality, Gender and Relationship Currency” cikk kategorizálja a felhasználókat a személyiségi jellemzőik alapján, amelyből kiderül, hogy az adatvédelem tudatos felhasználók, annál magasabb a nyitottság és az extrovertáltság személyiségi jellem értéke. A nemek közt nincs különbség a megosztás tekintetében, ámbár a nők hajlamosabbak az elővigyázatosságra és kevesebb információt osztanak meg magukról. (Kosinski, és mtsai., 2012)

\subsection{A Big 5 - személyiségi jellemzók}

A „Big 5” (magyarul „Nagy Ötös”) személyiségi jellemzők az akadémiai pszichológia egyik elfogadott és széles körben használt módszere az általános emberi jellemzők leírására. Az 5 alapvető emberi személyiségjegyet - amelynek létezését számos lélektani és biológiai háttérkutatás is igazolta - faktoranalízissel, empirikus mérési adatok elemzésével és a természetes nyelvből szisztematikusan összegyújtött és rendszerezett tulajdonságok elemzése útján nyerték ki. (Mirnics, 2006)

Az előző fejezetben ismertetett myPersonality Project eredményeképpen létrehozott pszichológiai API a vizsgált személyek személyiségjegyeit a Big 5 metodológia szerint adja vissza, emiatt a kutatásaim során én is ezt használtam.

A Big 5 által használt alap személyiségi jellemzők rendre:

- Nyitottság (openness) személyiségjegy az új kalandokra, ötletekre és esztétika befogadására való hajlandóság, kíváncsiság és képzelőerő.

- Lelkiismeretesség (conscientiousness) a rendszerezettség kedvelése. A lelkiismeretes emberek rendszerint ambiciózusak, talpraesettek és kitartóak.

- Extrovertált (extraversion) személyiségjeggyel rendelkező egyének társaságkedvelők, barátságosak és szociálisan aktívak. Rendszerint lendületesek, beszédesek, imádnak a figyelem középpontjában lenni és könnyen szereznek új barátokat. Az introvertált személyekre ezen 
tulajdonságok ellentettjei jellemzőek: jobban kedvelik a saját maguk társaságát és keresik a csendes, ingerszegény környezetet.

- A barátságos (agreeableness) emberek bizakodók, önzetlenek és gyengédek. Azon egyének, akik erre a kategóriára magas értéket kapnak, nagy valószínűséggel barátságosak, együttérzők és tapintatosak.

- A neurotikusság (neuroticism) jellemző az érzelmi felelősséggel bíró és impulzív személyekre. Esetenként gyors hangulatváltozások, negatív érzelmek (bűntudat, düh, szorongás, depresszió) jellemzik. (Kosinski, Bachrach, Kohli, Stillwell, \& Graepel, 2013)

\subsection{Apply Magic Sauce}

A myPersonality Project végeredményeképpen létrejött Facebook Like személyiségjegy adatbázis köré épített API neve: „Apply Magic Sauce”. A RESTful API-n keresztül elérhető szolgáltatás Facebook Like-okból képes megállapítani az egyén pszichológiai-demográfiai jellemzőit és egy regisztráció ellenében bárki számára elérhető.

$$
\begin{aligned}
& \text { „Apply Magic Sauce translates individuals' digital } \\
& \text { footprints into detailed psychological profiles” } \\
& \text { 17. ábra: Apply Magic Sauce - Prediction API alcíme }
\end{aligned}
$$

(The Psychometrics Centre, 2013)

Az API inputként a vizsgálandó Facebook felhasználó Like azonosítóinak halmazát várja és válaszként az alábbi személyes adatokat adja vissza: 
együttható ${ }^{26}$

\begin{tabular}{|l|r|}
\hline BIG5 & $0,35-0,5$ \\
\hline Élettel való elégedettség & $0,17 / 0,44$ \\
\hline Intelligencia & 0,47 \\
\hline Kor & 0,75 \\
\hline Nem & 0,93 \\
\hline Szexuális orientáció & férfiak esetében: 0,88 \\
& nók esetében: 0,75 \\
\hline Érdeklódési kör & 0,72 \\
\hline Politikai beállítottság & 0,79 \\
\hline Hitvallás & 0,76 \\
\hline Családi állapot & 0,67 \\
\hline
\end{tabular}

6. táblázat: Apply Magic Sauce API-ja által visszaadott személyes adatok

(The Psychometrics Centre, 2013)

Innen már csak egy lépés az, hogy a webboltokba bejelentkező vásárló személyiségét feltérképezzék pszichológiai API segítségével, majd a vásárló személyiségjegyei alapján ajánlanak termékeket számára vagy a híroldalakon megjelenő híreket a detektált érdeklődési körének megfelelően jelenítik meg.

Alessandro Acquisti (Carnegie Mellon University) 2013. júniusában tartott TED-es előadásában az előző gondolat valóságtartalmát igazolta a kutatásai során. A megnövekedett online aktivitás és közösségi hálózatra való információfeltöltés következtében bármilyen személyes információ, érzékeny információvá válhat. (Alessandro, 2013)

\subsection{Az adatelemzés}

Az online környezetben a valós személyek a személyiségi jellemzőiknek megfelelóen viselkednek. (Kosinksi, Stillwell, \& Graepel, 2013) Kutatásom keretében

\footnotetext{
${ }^{26}$ A Pearson féle korrelációs együtthatóval jellemezhető a változók közti lineáris kapcsolat szorosságát. (0,5 felett erôsnek, 0,3-0,5 között közepes erôsségú, és 0,1-0,3 között pedig gyenge erósségú) (Hunyadi \& Vita, 2006)
} 
azt szemléltetem, hogy a közösségi hálózatokon tanúsított viselkedések lenyomatáról elérhető információkból személyiségelemzést lehet elvégezni.

Készítettem egy Pentaho alkalmazást, amely kiolvassa a látogató like-jait az adatbázisból, elküldi azt az Apply Magic Sauce API-nak, majd a visszakapott eredményeket szintén elmenti a látogatóhoz társítva.

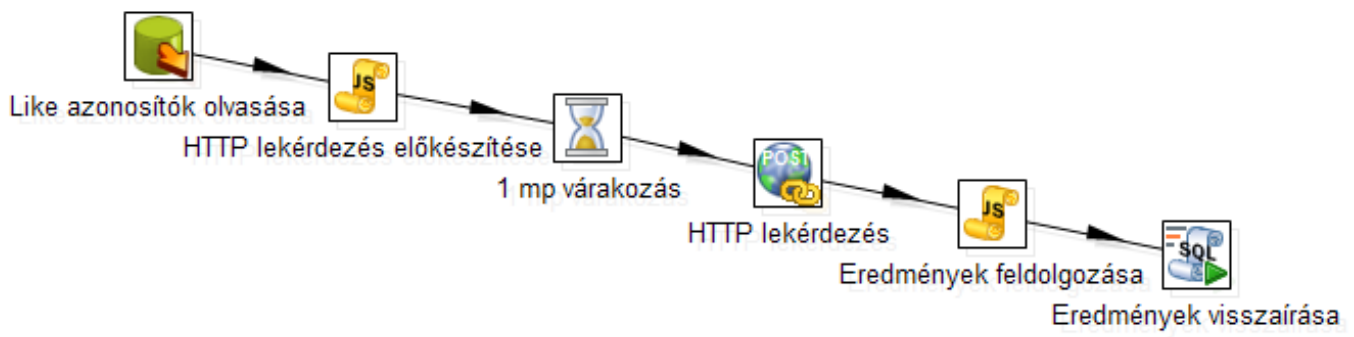

18. ábra: Facebook Like-okat személyiségi jegyekké feloldó Pentaho alkalmazás (saját szerkesztés)

Az API csak bizonyos számú Like esetén képes az illető személyiségi jellegzetességeit megjósolni, ezt a feltételt 48 egyén teljesítette a 139-ből. Ezt követően kezdtem neki az adatok elemzésének. Klaszterképző eljárásokkal hasonló egyéneket kerestem az így kapott mintában, majd az eredményt összevetettem a myPersonality Project adatgyújtő fázisában lementett adatokból képzett klaszterekkel.

\subsubsection{A myPersonality Project adatai}

A myPersonality Project adatbázisából a Big 5, a demográfiai, az IQ, az élettel való megelégedettség, a vallás és a politikai nézetek adattáblák adatait töltöttem le elemzési célból. A hozzá tartozó leírás szerint a letöltött mintában szereplő egyének korának átlaga 23,55 év. A mintában szereplő egyének 79,06\%-a USA, Egyesült Királyság, Kanada és Ausztrália területéről vett részt a kísérletben. (Kosinksi, Stillwell, \& Graepel, 2013)

\subsubsection{A statisztikai elemzés}

Először leíró statisztikákkal jellemeztem az elemzendő mintákat. Az eredmények táblázata az általam gyújtött és myPersonality Project keretében gyújtött átlagát és 95\%-os konfidencia intervallumát tartalmazza. (10-13. táblázat) 


\begin{tabular}{|c|c|c|c|c|c|c|}
\hline \multirow{3}{*}{$\begin{array}{l}\text { Big } 5 \\
\text { ságosság }\end{array}$} & \multicolumn{3}{|c|}{ myPersonality adat } & \multicolumn{3}{|c|}{ saját gyújtés } \\
\hline & \multirow{2}{*}{$\begin{array}{r}\text { Átlag } \\
, 6281\end{array}$} & \multicolumn{2}{|c|}{$\begin{array}{l}\text { 95\% konfidencia } \\
\text { intervallum }\end{array}$} & \multirow{2}{*}{$\begin{array}{r}\text { Átlag } \\
, 3413\end{array}$} & \multicolumn{2}{|c|}{$\begin{array}{l}\text { 95\% konfidencia } \\
\text { intervallum }\end{array}$} \\
\hline & & ,6207 & ,6354 & & ,3030 & ,3795 \\
\hline Lelkiismeretesség & ,5756 & ,5676 &, 5835 & ,4728 &, 4235 &, 5220 \\
\hline Nyitottság & ,7736 & ,7673 & ,7800 & ,4509 & ,4196 & ,4822 \\
\hline Neurotikusság & ,4473 & ,4377 & ,4569 &, 3245 & ,2892 & ,3597 \\
\hline Extrovertáltság &, 5323 &, 5227 & ,5418 & ,3765 & ,3431 & 4,4098 \\
\hline
\end{tabular}

7. táblázat: A Big 5 jellemzóinek átlaga és 95\%-os konfidencia intervalluma

\begin{tabular}{|l|r|r|r|r|r|r|}
\hline \multirow{2}{*}{ Családi viszony } & \multicolumn{3}{|c|}{ myPersonality adat } & \multicolumn{3}{c|}{ saját gyújtés } \\
\cline { 2 - 7 } & Átlag & \multicolumn{2}{c|}{$\begin{array}{r}95 \% \text { konfidencia } \\
\text { intervallum }\end{array}$} & Átlag & $\begin{array}{r}95 \% \text { konfidencia } \\
\text { intervallum }\end{array}$ \\
\hline Egyedülálló &, 4651 &, 4429 &, 4873 &, 5480 &, 5355 &, 5605 \\
\hline Házas &, 0857 &, 0733 &, 0982 &, 1449 &, 1349 &, 1550 \\
\hline Kapcsolatban &, 1828 &, 1656 &, 1999 &, 3071 &, 2980 &, 3161 \\
\hline
\end{tabular}

8. táblázat: A Big 5 jellemzóinek átlaga és 95\%-os konfidencia intervalluma

\begin{tabular}{|l|r|r|r|r|r|r|}
\hline \multirow{2}{*}{ Politikai nézet } & \multicolumn{3}{|c|}{ myPersonality adat } & \multicolumn{3}{c|}{ saját gyújtés } \\
\cline { 2 - 7 } & Átlag & \multicolumn{2}{c|}{$\begin{array}{r}95 \% \text { konfidencia } \\
\text { intervallum }\end{array}$} & Átlag & $\begin{array}{r}95 \% \text { konfidencia } \\
\text { intervallum }\end{array}$ \\
\hline Konzervatív &, 0103 &, 0058 &, 0147 &, 3171 &, 2917 &, 3425 \\
\hline Liberális &, 0277 &, 0204 &, 0350 &, 4072 &, 3783 &, 4361 \\
\hline $\begin{array}{l}\text { Nem érdekli a } \\
\text { politika }\end{array}$ &, 0154 &, 0099 &, 0209 &, 1676 &, 1538 &, 1814 \\
\hline Libertariánus &, 0062 &, 0027 &, 0096 &, 1081 &, 0979 &, 1183 \\
\hline
\end{tabular}

9. táblázat: A Big 5 jellemzóinek átlaga és 95\%-os konfidencia intervalluma 


\begin{tabular}{|l|r|r|r|r|r|r|}
\hline \multirow{2}{*}{ Egyéb változók } & \multicolumn{3}{|c|}{ myPersonality adat } & \multicolumn{3}{c|}{ saját gyújjtés } \\
\cline { 2 - 7 } & Átlag & \multicolumn{2}{c|}{$\begin{array}{c}95 \% \text { konfidencia } \\
\text { intervallum }\end{array}$} & Átlag & $\begin{array}{r}95 \% \text { konfidencia } \\
\text { intervallum }\end{array}$ \\
\hline Kor & 28,09 & 27,61 & 28,58 & 26,11 & 25,67 & 26,54 \\
\hline Barátok száma & 106,10 & 97,63 & 114,57 & 594,50 & 513,35 & 675,65 \\
\hline Intelligencia & 114,77 & 114,12 & 115,4 & 104,99 & 103,09 & 106,97 \\
\hline $\begin{array}{l}\text { Élettel valón } \\
\text { elégedettség }\end{array}$ &, 5337 &, 5231 &, 5442 &, 4536 &, 4180 &, 4891 \\
\hline
\end{tabular}

10. táblázat: A Big 5 jellemzóinek átlaga és 95\%-os konfidencia intervalluma

A leíró statisztikák táblázatából leolvasható, hogy a konfidencia intervallumoknak egy esetben sincs metszetük és a mintákban szereplő értékek átlagai szignifikánsan különböznek.

A myPersonality mintájában található egyének korának átlaga több, mint a saját gyújtésem egyéneinek kora, ami az Egyetemre járó diákok korával magyarázható. Érdekes, hogy a saját gyújtésemben található egyének intelligenciája és az élettel való megelégedettsége alacsonyabb, azonban jelentősen több ismerôsük van a közösségi hálón. Az összes Big 5 érték átlaga alacsonyabb a saját gyújtésem mintájában, mint a myPersonlity Project adatai esetében. Szintén meglepő, hogy a magyar mintában szereplő egyének politikai nézeteinek értékei jelentősen magasabbak. A politikától való tartózkodás is egyértelmú a magyar adatok esetében.
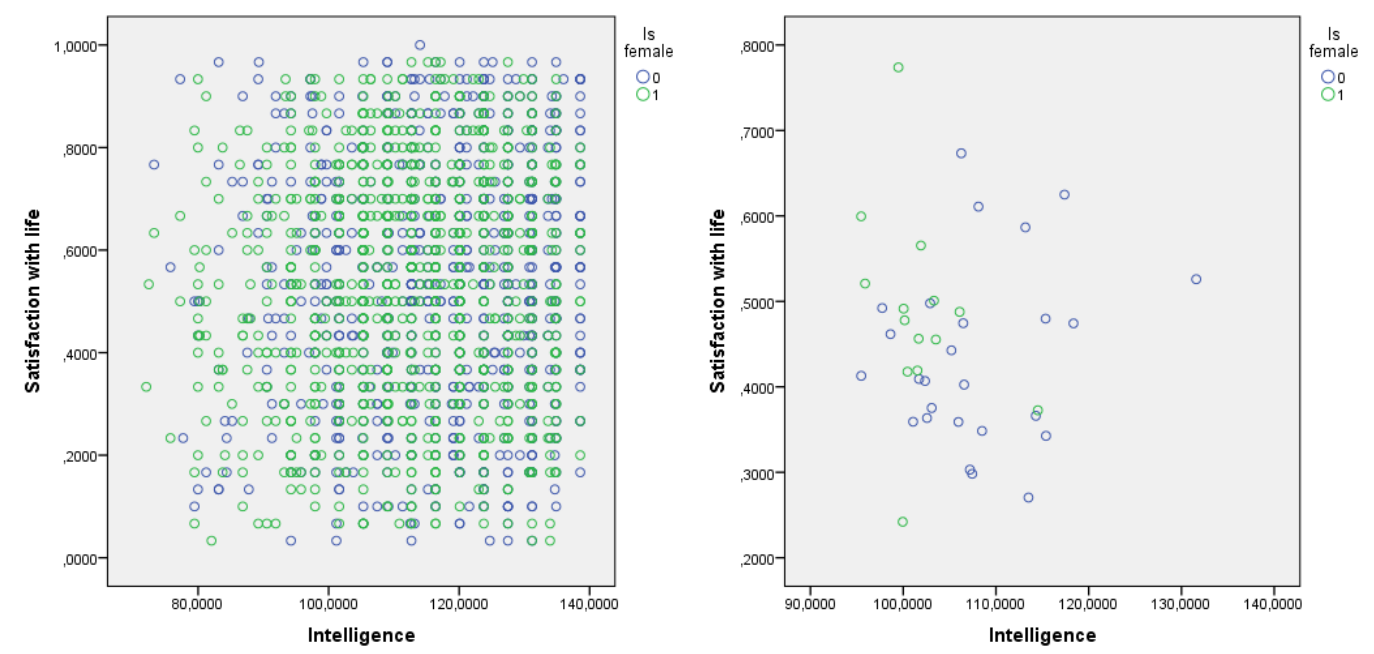

19. ábra: Az intelligencia és az élettel való elégedettségét megjelenítő scatterplot diagram 
Az intelligencia és az élettel való elégedettség változók kapcsolatának vizsgálatához az összetartozó értékeket scatterplot diagramon ábrázoltam. A diagram a két változó függetlenségét magyarázza, még akkor is, ha nemek szerint különválasztjuk az egyéneket.

\subsubsection{Klaszterelemzés}

A lementett személyiségi jegyek és demográfiai adatok halmazát klaszterező eljárásokkal elemeztem, amelynek célja a megfigyelési egységek homogén csoportokba rendezése a kiválasztott változók alapján. (Cser \& Fajszi, 2004) Az elemzést a myPersonality Project adatgyújtési fázisában összegyújtött adatokkal kezdtem, majd azt a saját adatgyújtésből származó adatokra is lefuttattam. K-közép és hierarchikus klaszterképző eljárások eredményének összevetéséből arra a megállapításra jutottam, hogy a kapott klaszterek stabilak.

\section{K-közép klaszterképzés}

A K-közép klaszterképző eljárás egyik hátránya, hogy eleve feltételezi a klaszterek létezését a mintában. Kezdetben 2, majd 3 és 4 klasztert feltételezve alakítottam ki a csoportokat. A távolság mérésére euklideszi távolság módszerét választottam, a kezdő középpontokat pedig az SPSS adta meg.

\begin{tabular}{|c|c|c|c|c|c|c|}
\hline \multicolumn{7}{|c|}{ ANOVA } \\
\hline & \multicolumn{2}{|l|}{ Cluster } & \multicolumn{2}{|c|}{ Error } & \multirow[b]{2}{*}{$\mathrm{F}$} & \multirow[b]{2}{*}{ Sig. } \\
\hline & Mean Square & $\mathrm{df}$ & Mean Square & df & & \\
\hline Big 5 Barátságosság & 8,910 & 1 &, 020 & 1946 & 434,660 &, 000 \\
\hline Big 5 Lelkiismeretesség & 8,901 & 1 &, 024 & 1946 & 366,586 &, 000 \\
\hline Big 5 Nyitottság & 1,892 & 1 &, 018 & 1946 & 106,342 &, 000 \\
\hline Big 5 Neurotikusság & 43,019 & 1 &, 022 & 1946 & 1945,223 &, 000 \\
\hline Big 5 Extrovertáltság & 30,532 & 1 & ,026 & 1946 & 1158,872 &, 000 \\
\hline
\end{tabular}

11. táblázat: A myPersonality Big 5 jellemzóinek ANOVA táblája

A myPersonality Project Big 5 adatain elvégzett klaszterképzés eredménye a 14. táblázatban látható. A létrehozott 2 klaszter értékei szignifikánsan eltérnek egymástól, amit az alacsony p-érték és az F-tesztek is alátámasztanak.

Ezt követően az egyéneket a politikai nézeteik alapján klaszterezni. A kapott eredmények a 15. táblázatban láthatóak. Az eredmények alapján - a liberális nézeteket valló egyéneken kívül - a klaszterek nem szignifikánsak, mivel a p-érték és az Ftesztek értékei az 5\%-os szignifikancia szint felett vannak. 
ANOVA

\begin{tabular}{|l|r|r|r|r|r|r|}
\hline & \multicolumn{2}{|c|}{ Cluster } & \multicolumn{2}{c|}{ Error } & \\
\cline { 2 - 6 } & Mean Square & df & Mean Square & \multicolumn{1}{c|}{ df } & \multicolumn{1}{c|}{ F } & Sig. \\
\hline Konzervatív &, 006 & 1 &, 010 & 1946 &, 576 &, 448 \\
Liberális & 52,503 & 1 &, 000 & 1946 & $\cdot$ & $\cdot$ \\
Nem érdeklődik &, 013 & 1 &, 015 & 1946 &, 868 &, 352 \\
Libertariánus &, 002 & 1 &, 006 & 1946 &, 344 &, 558 \\
\hline
\end{tabular}

12. táblázat: A myPersonality politikai jellemzóinek ANOVA táblája

A 16. táblázat alapján a családi állapot jellemzők alapján megfelelő minőségben lehet klasztereket képezni.

ANOVA

\begin{tabular}{|l|r|r|r|r|r|r|}
\hline & \multicolumn{2}{|c|}{ Cluster } & \multicolumn{2}{c|}{ Error } & \\
\cline { 2 - 7 } & Mean Square & df & Mean Square & \multicolumn{1}{c|}{ df } & F & Sig. \\
\hline Egyedülálló & 39,511 & 1 &, 229 & 1946 & 172,739 &, 000 \\
Házas & 152,683 & 1 &, 000 & 1946 &. &. \\
Kapcsolatban & 6,100 & 1 &, 146 & 1946 & 41,678 &, 000 \\
\hline
\end{tabular}

13. táblázat: A myPersonality családi állapot jellemzóinek ANOVA táblája

A klaszterek képzése során elmentettem a klaszter tagságot, ami lehetővé teszi azok összevetését. Az összevetést kereszttábla (crosstab) módszerrel végeztem, az eredményt a 17. táblázat tartalmazza. A B_clusters a Big 5 értékei alapján készített klasztereket veti össze a S_cluster a családi állapot alapján készített klasztertagsággal.

B_clusters * S_clusters Crosstabulation

\begin{tabular}{|ll|r|r|r|}
\hline & \multicolumn{2}{|c|}{ Sount } & \multicolumn{2}{|c|}{} \\
\cline { 3 - 4 } & & 1 & 2 & \multirow{2}{*}{ Total } \\
\hline B_clusters & 1 & 872 & 72 & 944 \\
& 2 & 909 & 95 & 1004 \\
& & 1781 & 167 & 1948 \\
\hline
\end{tabular}

14. táblázat: A klaszter tagság kereszttáblája

A kapott eredmény alapján kijelenthető, hogy a klaszterek függetlenek egymástól, amelyet ellenőrizhetünk a Pearson Chi-Square $(2,090)$ értékével és a hozzá tartozó p-értékkel $(0,148)$. Mivel a kapott p-érték nem kisebb az 5\%-os szignifikancia 
szintnél, a nullhipotézis nem vethető el, amely a 3 dimenziós hisztogramról is jól látszik.

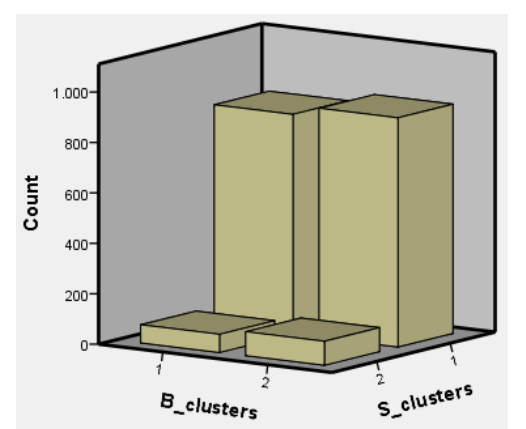

20. ábra: A klaszterek 3 dimenziós hisztogramja

A politikai nézet jellemzők nem megfelelő klaszterképző ereje miatt azokat nem vettem bele a végső klaszterképző algoritmusba, azonban a Big 5 és a családi állapot jellemzőket azok függetlensége miatt igen. Az algoritmust lefuttattam 2, 3 és 4 klaszter esetére, amiből kiderült, hogy a 4 klaszter a megfelelő választás, mivel ebben az esetben lesz a változók szétválasztó ereje a legnagyobb.

ANOVA

\begin{tabular}{|l|r|r|r|r|r|r|}
\hline & \multicolumn{2}{|c|}{ Cluster } & \multicolumn{2}{c|}{ Error } & & \\
\cline { 2 - 6 } & Mean Square & df & Mean Square & df & F & Sig. \\
\hline Big 5 Barátságosság &, 065 & 3 &, 025 & 1944 & 2,612 &, 050 \\
Big 5 Lelkiismeretesség &, 236 & 3 &, 029 & 1944 & 8,265 &, 000 \\
Big 5 Nyitottság &, 106 & 3 &, 019 & 1944 & 5,683 &, 001 \\
Big 5 Neurotikusság &, 070 & 3 &, 044 & 1944 & 1,586 &, 191 \\
Big 5 Extrovertáltság &, 151 & 3 &, 042 & 1944 & 3,610 &, 013 \\
Egyedülálló & 161,542 & 3 &, 000 & 1944 &. &. \\
Házas & 50,894 & 3 &, 000 & 1944 &. &. \\
Kapcsolatban & 96,980 & 3 &, 000 & 1944 &. &. \\
\hline
\end{tabular}

15. táblázat: A Big 5 és a családi állapot klasztereinek ANOVA táblája

A családi állapot jellemzőknek nincs F-értéke és p-értéke, mert azok alapján az egyének teljes mértékben elkülöníthetők. A végső klaszter középpontok a 19. táblázatban tekinthetốek meg. 
Final Cluster Centers

\begin{tabular}{|l|r|r|r|r|}
\hline & \multicolumn{5}{|c|}{ Cluster } \\
\cline { 2 - 5 } & 1 & \multicolumn{1}{|c|}{2} & \multicolumn{1}{c|}{3} & \multicolumn{1}{c|}{4} \\
\hline Big 5 Barátságosság &, 6126 &, 6346 &, 6259 &, 6418 \\
Big 5 Lelkiismeretesség &, 5712 &, 5715 &, 5566 &, 6334 \\
Big 5 Nyitottság &, 7811 &, 7678 &, 7888 &, 7410 \\
Big 5 Neurotikusság &, 4566 &, 4385 &, 4639 &, 4453 \\
Big 5 Extrovertáltság &, 5250 &, 5218 &, 5583 &, 5550 \\
Egyedülálló & 0 & 1 & 0 & 0 \\
Házas & 0 & 0 & 0 & 1 \\
Kapcsolatban & 0 & 0 & 1 & 0 \\
\hline
\end{tabular}

16. táblázat: Végsó klaszter középpontok

\section{Hierarchikus klaszterképzés}

A kapott eredmények validálása miatt a hierarchikus klaszterképző eljárást is lefuttattam a kiválasztott jellemzőire. A klaszterképző eljárás paramétereiben Ward metódusát, a távolság számítására euklideszi távolságot használtam. A Ward-féle varianciamódszer azokat a klasztereket vonja össze, melyek esetében az összevonás során a belső szórásnégyzet növekedése a legkisebb lesz és ezzel egyenlő elemszámú klaszterek kialakítására törekszik. (Kovács E. , 2014) A hierarchikus klaszterezés előnye, hogy nem szükséges előre tudnom a klaszterek számát, mert az leolvasható az algoritmus eredményeképpen létrejött dendrogramról. Esetemben a hierarchikus klaszterezés igazolta a megfelelően kiválasztott 4 klasztert.

A két különféle klaszterképző eljárással klaszterekbe sorolt egyének tagságát elmentettem, majd egy kereszttábla elemzéssel vetettem össze óket.

Count

\begin{tabular}{|ll|r|r|r|r|r|}
\hline \multirow{2}{*}{} & \multicolumn{9}{|c|}{ Ward Method } & \multicolumn{1}{c|}{} \\
\cline { 2 - 6 } & 1 & 1 & 2 & 3 & 4 & Total \\
\hline Cluster Number of Case & 1 & 0 & 519 & 0 & 0 & 519 \\
& 2 & 906 & 0 & 0 & 0 & 906 \\
& 3 & 0 & 0 & 0 & 356 & 356 \\
& 4 & 0 & 0 & 167 & 0 & 167 \\
Total & 906 & 519 & 167 & 356 & 1948 \\
\hline
\end{tabular}

17. táblázat: Klaszterek kereszttáblája 
A kereszttábla elemzés eredménye a 20. táblázatban tekinthető meg, amely igazolta, hogy a két klaszterképző eljárással képzett klaszterek megegyeznek, tehát azok stabilak.

\section{Saját adatok elemzése}

A klaszterképző eljárásokat az általam összegyújtött adatokra is lefuttattam. A futtatások alkalmával az algoritmusokat az előzőekben ismertetett paraméterekkel használtam és a Big 5, politikai nézet és a családi állapot változókat vettem be a vizsgálatba. Az eredményeket a 18. táblázat: Big 5 klaszterek ANOVA táblája, a 19. táblázat: Politikai nézet ANOVA táblája és a 20. táblázat: Családi állapot ANOVA táblája tartalmazza.

\begin{tabular}{|l|r|r|r|r|r|r|}
\hline & \multicolumn{2}{|c|}{ ANOVA } & & \\
\cline { 2 - 7 } & Mean Square & df & Mean Square & df & \multicolumn{1}{c|}{ F } & \multicolumn{1}{c|}{ Sig. } \\
\hline &, 067 & 1 &, 013 & 38 & 5,140 &, 029 \\
Big 5 Barátságosság &, 611 & 1 &, 008 & 38 & 74,019 &, 000 \\
Big 5 Lelkiismeretesség &, 038 & 1 &, 009 & 38 & 4,317 &, 045 \\
Big 5 Nyitottság &, 069 & 1 &, 011 & 38 & 6,454 &, 015 \\
Big 5 Neurotikusság &, 064 & 1 &, 009 & 38 & 6,747 &, 013 \\
Big 5 Extrovertáltság & & 1 & Error \\
\hline
\end{tabular}

18. táblázat: Big 5 klaszterek ANOVA táblája

\section{ANOVA}

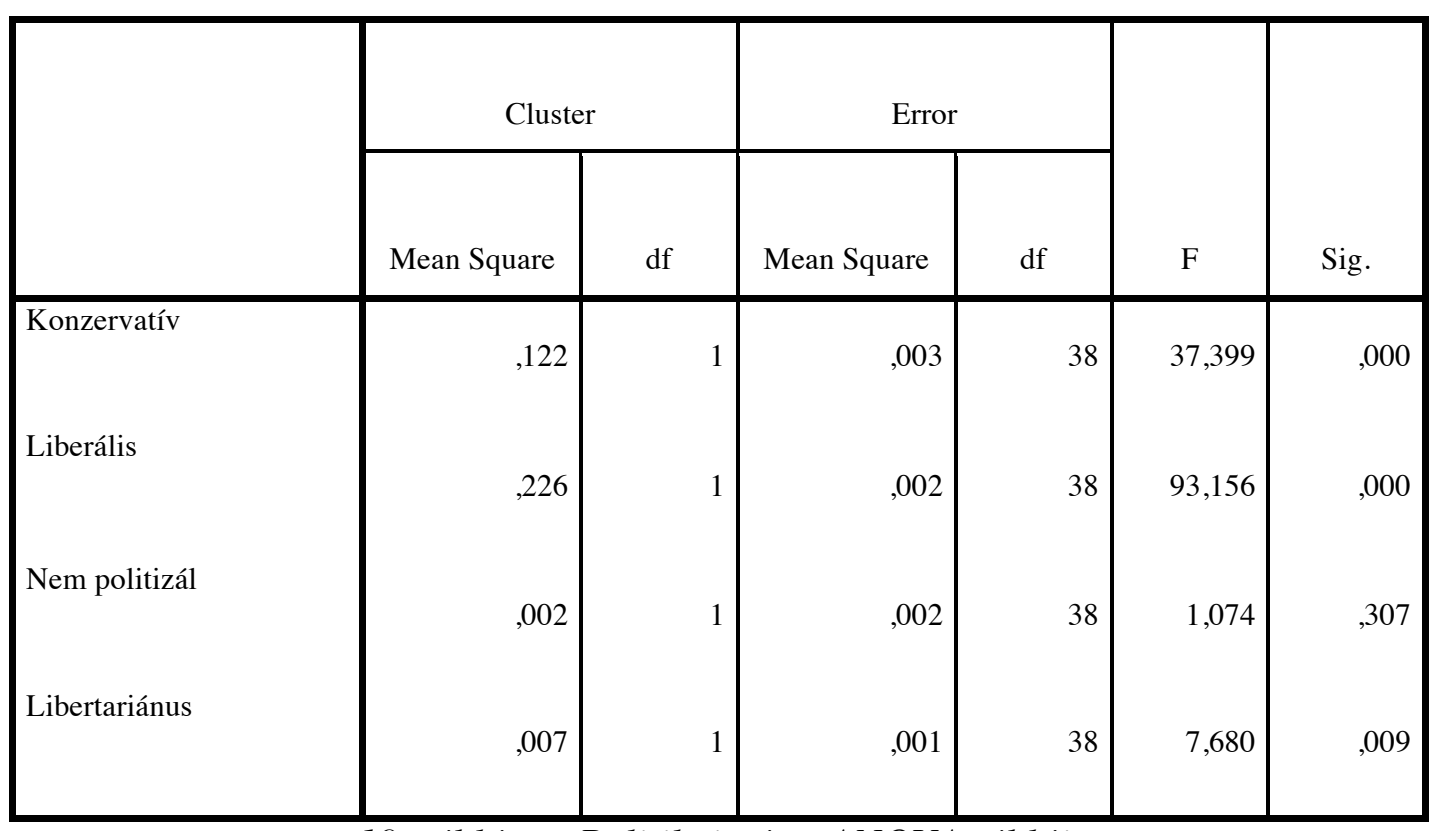


A 14. táblázatban a „Nem politizál” változó kivételével mindegyik változó szignifikáns és hozzájárul a klaszter kialakításához.

ANOVA

\begin{tabular}{|l|r|r|r|r|r|r|}
\hline & \multicolumn{3}{|c|}{ Cluster } & \multicolumn{2}{c|}{ Error } & \\
\cline { 2 - 7 } & Mean Square & df & Mean Square & df & \multicolumn{1}{c|}{ F } & Sig. \\
\hline Egyedülálló &, 032 & 1 &, 001 & 38 & 43,480 &, 000 \\
Házas &, 013 & 1 &, 001 & 38 & 18,541 &, 000 \\
Kapcsolatban &, 004 & 1 &, 001 & 38 & 6,064 &, 018 \\
\hline
\end{tabular}

A Big 5 és a családi állapot klaszterek összehasonlításának eredménye a 21. táblázatban látható.

B_clusters * S_clusters Crosstabulation

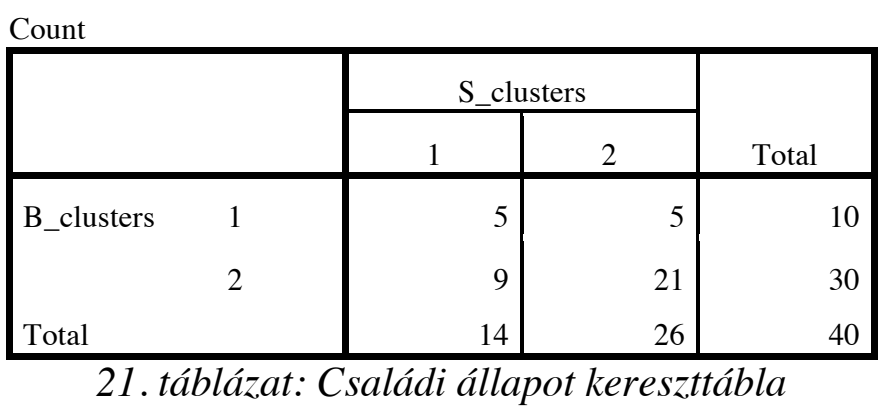

A táblázat a változók függetlenségét sugallja, de a mintában lévő elemek alacsony száma miatt ebben nem lehetünk biztosak. A függetlenségi vizsgálat eredménye 1,319 Pearson Chi-Square érték és 0,251 p-érték, így a függetlenség hipotézisét nem vethetjük el 5\%-os szignifikancia szinten.

Ezt követően a K-közép klaszterképző algoritmus lefuttattam 2, 3 és 4 klaszterre is. Az eredmények szerint 3 klaszter esetében az összes elemzésbe bevett változó szignifikáns. 


\begin{tabular}{|l|r|r|r|r|r|r|}
\hline & \multicolumn{7}{|c|}{ ANOVA } & & \\
\cline { 2 - 6 } & Cluster & \multicolumn{2}{c|}{ Error } & \multicolumn{1}{c|}{ Sig. } \\
\hline & Mean Square & df & Mean Square & df & F &, 000 \\
Big 5 Barátságosság &, 145 & 2 &, 007 & 37 & 20,077 &, 000 \\
Big 5 Lelkiismeretesség &, 343 & 2 &, 006 & 37 & 52,967 &, 000 \\
Big 5 Nyitottság &, 066 & 2 &, 007 & 37 & 10,097 &, 210 \\
Big 5 Neurotikusság &, 019 & 2 &, 012 & 37 & 1,631 &, 157 \\
Big 5 Extrovertáltság &, 020 & 2 &, 010 & 37 & 1,949 &, 057 \\
Egyedülálló &, 004 & 2 &, 001 & 37 & 3,096 &, 036 \\
Házas &, 003 & 2 &, 001 & 37 & 3,630 &, 002 \\
Kapcsolatban &, 004 & 2 &, 001 & 37 & 7,272 &, \\
\hline
\end{tabular}

22. táblázat: A BIG5 és a családi állapot változóinak ANOVA táblája

A hierarchikus klaszterelemzésnél használatos dendrogramról leolvasható, hogy 2 vagy 3 klaszter képzése a megfelelő választás. Az összehasonlítás során 2 klaszter képzése esetén az ANOVA táblából leolvasható, hogy a házas (Married) változó nem szignifikáns, ezért 3 klasztert képeztem. 


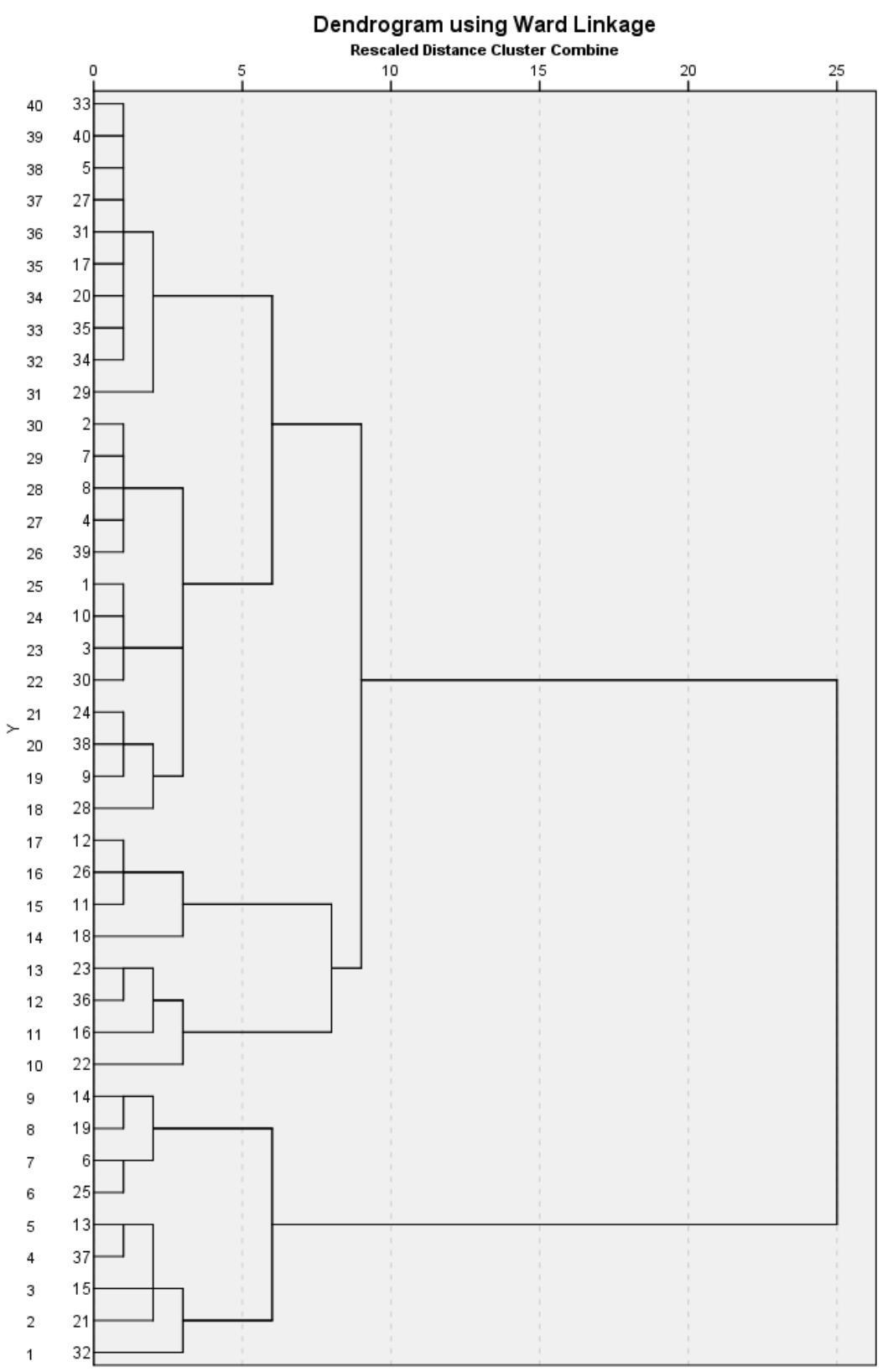

21.ábra: Hierarchikus klaszterelemzés dendrogramja

A K-közép és a hierarchikus klaszterezés eredményeinek összehasonlításának végeredménye a 23. táblázatban látható: a két klaszterképző eljárás majdnem ugyanazt az eredményt adta, így kijelenthető, hogy a képzett klaszterek stabilak. 


\begin{tabular}{|c|c|c|c|c|c|}
\hline \multicolumn{2}{|c|}{ Ward Method } & \multicolumn{4}{|c|}{ * Cluster Number of Case Crosstabulation } \\
\hline \multicolumn{6}{|l|}{ Count } \\
\hline & & \multicolumn{3}{|c|}{ Cluster Number of Case } & \multirow[b]{2}{*}{ Total } \\
\hline & & 1 & 2 & 3 & \\
\hline \multirow[t]{3}{*}{ Ward Method } & 1 & 0 & 22 & 1 & 23 \\
\hline & 2 & 8 & 1 & 0 & 9 \\
\hline & 3 & 0 & 1 & 7 & 8 \\
\hline Total & & 8 & 24 & 8 & 40 \\
\hline
\end{tabular}

23. táblázat: Klaszter tagság ellenórzés

\subsubsection{Az eredmények kiértékelése}

A végső klaszter középpontokat tartalmazó táblázatokat hasonlítottam össze, amelyekből megállapítható, hogy a Corvinus Egyetem polgárai milyen jellegzetességekkel rendelkeznek.

Final Cluster Centers

\begin{tabular}{|l|r|r|r|r|}
\hline \multirow{2}{*}{} & \multicolumn{5}{|c|}{ Cluster } \\
\cline { 2 - 5 } & 1 & 2 & \multicolumn{1}{c|}{3} & \multicolumn{1}{c|}{4} \\
\hline Big 5 Barátságosság &, 6126 &, 6346 &, 6259 &, 6418 \\
Big 5 Lelkiismeretesség &, 5712 &, 5715 &, 5566 &, 6334 \\
Big 5 Nyitottság &, 7811 &, 7678 &, 7888 &, 7410 \\
Big 5 Neurotikusság &, 4566 &, 4385 &, 4639 &, 4453 \\
Big 5 Extrovertáltság &, 5250 &, 5218 &, 5583 &, 5550 \\
Egyedülálló & 0 & 1 & 0 & 0 \\
Házas & 0 & 0 & 0 & 1 \\
Kapcsolatban & 0 & 0 & 1 & 0 \\
\hline
\end{tabular}

24. táblázat: myPersonality Project adatainak K-középpontú klaszterei

Final Cluster Centers

\begin{tabular}{|l|r|r|r|}
\hline \multirow{2}{*}{} & \multicolumn{3}{|c|}{ Cluster } \\
\cline { 2 - 4 } & 1 & \multicolumn{1}{|c|}{2} & \multicolumn{1}{c|}{3} \\
\hline Big 5 Barátságosság &, 2284 &, 4107 &, 2457 \\
Big 5 Lelkiismeretesség &, 7207 &, 4379 &, 3293 \\
Big 5 Nyitottság &, 4235 &, 4217 &, 5659 \\
Big 5 Neurotikusság &, 2667 &, 3317 &, 3605 \\
Big 5 Extrovertáltság &, 4400 &, 3597 &, 3632 \\
Egyedülálló &, 5749 &, 5376 &, 5522 \\
Házas &, 1442 &, 1532 &, 1207 \\
Kapcsolatban &, 2809 &, 3091 &, 3271 \\
\hline
\end{tabular}

25. táblázat: a saját adatok K-középpontú klaszterei 
A myPersonality Project adatokból képzett klaszterek értelmezése:

- Valódi életet élók: Ámbár nyitottnak tûnnek, nem sokat fednek fel magukból a Facebook-on, valószínúleg kevés időt töltenek a közösségi hálózaton.

- Magányosak: Nincsenek kapcsolatban és nem élnek társasági életet a Facebook-on.

- Beszédesek: Ez a kapcsolatban lévő emberek rendelkeznek a legmagasabb nyitottság, neurotikusság és extrovertáltság értékével. Leginkább ők érzik szükségét a közösségi hálózaton történő megosztásnak.

- Komolyak: Házas, kompromisszumképes és lelkiismeretes csoport.

A Corvinus Egyetem polgárainak adatait elemezve az alábbi 3 csoportot állapítottam meg:

A táblázatból leolvasható az alábbi 3 klaszter és a feltételezhető magyarázatuk:

- Elmélkedők: Nagy valószínúséggel nincsenek kapcsolatban, de meglehetősen extrovertáltak és lelkiismeretesek.

- Komolyak: A legkellemesebb személyiséggel rendelkezők, szintén lelkiismeretesek, valószínúleg házasok vagy komoly kapcsolatban vannak.

- Beszédesek: Nagyon nyitott és extrovertált személyek, akik valószínúleg kapcsolatban vannak.

\section{5. Összegzés}

A myPersonality Project keretében összegyújtött nemzetközi adatokban és a saját adatgyújtés eredményeképpen létrejött adatokban klasztereket képeztem nem felügyelt tanulási algoritmusokkal, majd a kapott eredményeket összevetettem. A kutatás eredményeképpen megállapítható, hogy a különböző forrású adatokban hasonló egyének csoportjai vettek részt, annak ellenére, hogy a myPersonality Project keretében gyújtött adatok fóként az angolszász országok polgárai, a saját kutatásomban pedig a Budapesti Corvinus Egyetem polgárai vettek részt.

A kutatásom idejében a Facebook like-ok pszichológiai elemzése során kinyerhető az egyénre jellemző Big5 személyiségi jellemzők, az élettel való elégedettség, intelligencia, kor, nem, szexuális orientáció, érdeklődési kör, politikai beállítottság, hitvallás és családi állapot. A pszichológiai API a Facebook like-okból visszaadott változók bizonyosságát a Pearson-féle korrelációs együtthatóval jellemzi, 
amely szerint többségük (kor, nem, szexuális orientáció, érdeklődési kör, politikai beállítottság, hitvallás és családi állapot) igen erős ${ }^{27}$ lineáris kapcsolatot, míg néhány (Big5, élettel való elégedettség és intelligencia) paraméter közepesen erős kapcsolatot mutat. A különböző forrású mintákon K-közép és hierarchikus klaszterképző eljárásokat futtattam, amelynek eredményeképpen létrejött klaszterek mindkét módszer esetében ugyanazokat eredményezte, így azok stabilnak mondhatók.

A vizsgált mintákban (myPersonality Project és a Corvinus Egyetem polgárai) kettő nagyon hasonló klaszter lelhető fel: a magas nyitottság, neurotikusság és extrovertáltság értékkel rendelkező tartalommegosztók, akik nagy valószínúséggel nincsenek kapcsolatban és a komoly kapcsolatban lévő, kompromisszumra képes, lelkiismeretesek egyének. Emellett a myPersonality Project mintájából kimutatható még a közösségi hálózaton kevés időt töltő egyének csoportja, akik feltételezhetően a Corvinus Egyetem polgárainak mintájában is jelen vannak.

${ }^{27}$ A Pearson-féle korrelációs együttható értéke magasabb, mint 0,67 


\section{SZEMÉLYES INFORMÁCIÓ KINYERÉSE WEBES ADATOKBÓL}

A kutatók egyetértenek abban, hogy az egyén online tanúsított viselkedéséből és kinyilvánított preferenciáiból a személyes jellemzői kikövetkeztethetők. (Kosinski, Stillwell, \& Graepel, 2013)

Az Az Egyetemi polgárok pszichológiai jellemzói adatvédelmi szempontból címú kutatásom során a Facebook-os adatokból kinyert személyes jellemzőket a látogatók adataihoz társítva elmentettem egy adatbázisba. Ezt követően az online környezetben tanúsított viselkedés és a környezeti jellemzőkből következtettem a látogatók személyes tulajdonságaira. A kutatásban vizsgált mintában a személyhez nem köthető változók az attribútum halmaz elemei, a személyes tulajdonságok pedig a potenciális osztályváltozók.

A kutatásom során több klasszifikációs algoritmust, többek között a népszerú Apriori algoritmust is használtam, amely nagy adathalmazokban képes hatékonyan asszociációs szabályok keresésére. (Agrawal \& Srikant, 1994) Az Apriori algoritmust több adatbányászati alkalmazásba is implementálták, én a Java alapú Wekát használtam. (Witten, Frank, \& Hall, 2011)

$\mathrm{Az}$ Apriori algoritmus gyakori elemhalmazok elemzésével nyeri ki az asszociációs szabályokat. Az algoritmus kihasználja a gyakori elemhalmazok részhalmaza is gyakori axiómát, ezáltal az algoritmus hatékonyan tudja csökkenteni a kinyert szabályok számát, melyek közül csak azok lesznek érdekesek, amelyek egy minimális support (támogatottság) értéknél nem kevesebb. (Agrawal \& Srikant, 1994) Már egészen kis minták esetében is rengeteg különböző asszociációs szabály nyerhető ki, az algoritmus csak azokat tartja meg, amely viszonylag nagy számú példányra érvényes. Ezen szabályokat érdekesnek hívjuk. Az algoritmus kimenetének minőségét az alábbi mutatókkal jellemzem:

- Support (támogatás): az asszociációs szabály helyesen képes előre jelezni a mintában található egyedei ennyi százalékára.

- Confidence (bizalom): az egyedek hány százalékára érvényes egy szabály

- Significance (szignifikancia): $\chi 2$ függetlenségi teszt eredménye, annak vizsgálatára, hogy statisztikailag kimutatható kapcsolat van egy szabály jobb 
és bal oldala között. A null hipotézis esetén a bal és a jobb oldal függetlenek. Egy szabály elvethető - egy meghatározott szignifikancia szint mellett amennyiben a khi-négyzet valószínúség kisebb, mint a szignifikancia szint.

- Precision (pontosság): százalékban kifejezett érték, egy szabály esetében azon egyedek aránya, amelyek helyesen lettek kiválasztva.

$$
\text { Pontosság = valós pozitív / (valós pozitív + ál-pozitív) }
$$

- Recall (visszahívás): azon helyes értékek százaléka, amelyeket a szabály kiválasztott

$$
\text { Visszahívás }=\text { valós pozitív / (valós pozitív }+ \text { ál-negatív })
$$

- F-score (F-érték): kombinált érték, amely a precision - recall közti viszonyt jellemzi (súlyozott harmónikus átlag) (Jurafsky \& Manning, 2012)

$$
\text { F-score }=(2 \times \text { Precision } \times \text { Recall }) /(\text { Precision }+ \text { Recall })
$$

A kutatáshoz az adatokat $4.2 \mathrm{Az}$ adatgyüjtő alkalmazás címú fejezetben leírtak szerint gyújtöttem a Budapesti Corvinus Egyetem polgárairól. A kigyújtött Facebook Like-okat az $5.4 \mathrm{Az}$ adatelemzés címú fejezetben leírt pszichológiai API-val dolgoztattam fel és a kapott eredményeket elmentettem az adatbázisba a látogatók adataihoz. Az API csak megfelelő számú Facebook Like esetén képes személyes tulajdonságok jóslására. A 139 látogatóból összesen 95 látogatónak elegendő like-ja, az érvényes kimenethez. A jelen kutatáshoz az alábbi személyes jellemzőket mentettem el: Big5 (barátságosság, lelkiismeretesség, extrovertáltság, nyitottság, neurotikusság), IQ, élettel való megelégedettség, hit és politikai beállítottság.

\subsection{Az adatok elókészítése}

Az Apriori algoritmus kizárólag névleges (nominális) típusú változókat képes elfogadni inputként, ennek megfelelôen a numerikus értékeket nominálissá kell konvertálni az algoritmus használata előtt. A névleges (nominális) mérési skála kizárólag az egységekhez rendelt számértékek egyező vagy különböző voltának jellemzésére alkalmas. Az adatbázisból kiexportált azon mezők esetében, ahol az értékek pusztán kódszámoknak tekinthetőek, ez az átalakítás pusztán formalitás. (Hunyadi \& Vita, 2006)

Az alábbi lista tartalmazza, hogy milyen átalakításokat végeztem az adatokon: 


\section{- Binárissá alakítás}

○ Ha az input változó értéke 0 , akkor az output értéke 0 , minden más esetben az output értéke 1

○ Átalakított nominális változók: is_DNT_on ${ }^{28}$, has_flash, is_flash_blocked, has_silverlight, has_quicktime, has_java, has_PDFReader,has_AdobeReader, activity_dawn, activity_forenoon, activity_noon, activity_afternoon, activity_evening, activity_night

\section{- Binárissá alakítás vágással}

○ Ha az input változó értéke 0,5-nél kevesebb, akkor az output értéke 0 , más esetben az output értéke 1

○ Átalakított nominális változók: s_yes, r_christian, b_agreeableness, b_conscientiousness, b_openness, b_neuroticism, b_extraversion, p_uninvolved, p_conservative, female

\section{- Kategóriaváltozóvá alakítás}

- A Weka Discretize szúrőjét alkalmazva az input változó értékeit különböző kategóriákba soroltam, az inputváltozó mögötti zárójelben látható a létrehozott kategória száma

○ Átalakított ordinális skálán értelmezett változók: connection_type (2), font_counter (2), number_of_pageloads (3), cardinality_of_sessions (6), cardinality_of_locations (2), satisfaction_life (3), intelligence (3)

- Nem változtatott

○ Nem szükséges átalakítás, mivel az SQL lekérdezés végeredménye az Apriori algoritmus számára feldolgozható

○ Változók: browserFamily, osFamily, device, mobile_os_family, screen_size, geo_category, course, department

\subsection{Elemzés}

\subsubsection{Klasszifikációs algoritmusok}

Az osztályváltozó előrejelzésének pontosságát megjósolandó az alábbi klasszifikációs algoritmusokat alkalmaztam a mintára:

\footnotetext{
${ }^{28}$ A változók értelmezése a 8.7.5 fejezetben olvasható
} 
- ZeroR: Nincs előrejelzési képessége, mert nem használ fel egyetlen attribútumot sem, pusztán viszonyítási alapként használatos. Egy feltétel nélküli szabály, amely ítéletrészében a leggyakoribb osztály áll. Az algoritmus összeállít egy gyakorisági táblázatot, majd kiválasztja a leggyakoribb értéket. (Bodon, 2010)

- OneR: A legegyszerúbb osztályozó algoritmus. Kiválaszt egy attribútumot és az osztályozásban kizárólag ezt használja. Annyi szabályt állít elő, ahány értéket felvesz a kiválasztott attribútum a tanítóhalmazban. (Bodon, 2010)

- NaiveBayes: A Bayes-tételen alapszik, mely az egyes attribútumok közötti függetlenséget feltételez. Egyszerúsége ellenére, széles körben elterjedt és meglepően jól teljesítő algoritmus. (Bodon, 2010)

- J48: Döntési fa algoritmus, az ID3 (Iterative Dichotomiser 3) algortimus implementációja. (Bodon, 2010)

- RandomForest: A véletlen erdők hatékony osztályozó algoritmusok, amelyek döntési fákat használva nagy adathalmazokkal is megbirkóznak. (Szabó, 2010)

Minden klasszifikációs algoritmus futtatása előtt kiválasztottam egy osztályváltozót, a többit pedig eltávolítottam a mintából, ezzel biztosítva, hogy azok a létrehozott szabályokban ne szerepeljenek. 


\begin{tabular}{|c|c|c|c|c|c|c|c|}
\hline \multirow[b]{2}{*}{ 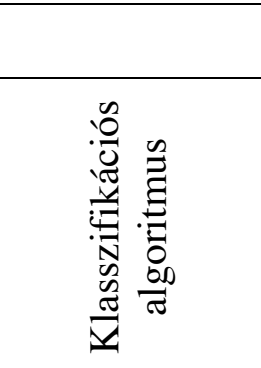 } & \multicolumn{7}{|c|}{ Kiválasztott osztályváltozó } \\
\hline & 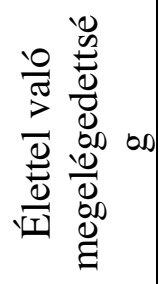 & $\begin{array}{l}\cdot \frac{\pi}{U} \\
\frac{0}{0} \\
.000 \\
\bar{\Xi} \\
\stackrel{\Xi}{\Xi}\end{array}$ & 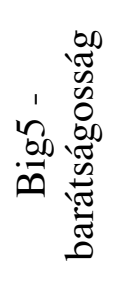 & 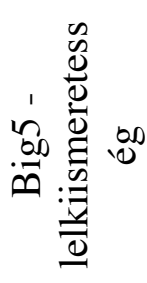 & 它 & 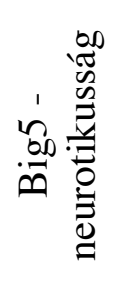 & 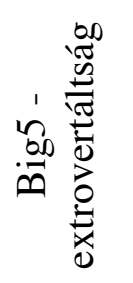 \\
\hline ZeroR & 85,3 & 85,3 & 67,4 & 73,7 & 69,5 & 65,3 & 67,4 \\
\hline OneR & 82,4 & 82,4 & 65,3 & 70,5 & 68,4 & 60,0 & 64,2 \\
\hline Naïve-Bayes & 79,4 & 76,5 & 55,8 & 69,5 & 60,0 & 50,5 & 54,7 \\
\hline $\mathrm{J} 48$ & 85,3 & 85,3 & 66,3 & 65,3 & 69,5 & 63,2 & 63,2 \\
\hline RandomForest & 85,3 & 85,3 & 58,9 & 68,4 & 61,0 & 53,7 & 57,9 \\
\hline
\end{tabular}

26. táblázat: az alkalmazott osztályozó algoritmusok által helyesen osztályozott

változók százalékos aránya

A 26. táblázat eredményeiből kitúnik, hogy a ZeroR osztályozó algoritmus több esetben is felülmúlja a kifinomultabb algoritmusokat. Az élettel való elégedettség és az intelligencia jelezhető előre a legpontosabban a vizsgált osztályváltozók közül, emiatt a kutatás további részeiben csak ezekkel a változókkal fogok foglalkozni.

Az élettel való megelégedettség és az intelligencia esetében is a precision (pontosság) értéke 0,728, a recall (visszahívás) értéke 0,853 és az F-érték pedig 0,785 a legjobban teljesítő algoritmusok esetében (ZeroR, J48, RandomForest). 


\begin{tabular}{|c|c|c|c|c|c|c|}
\hline 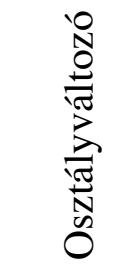 & 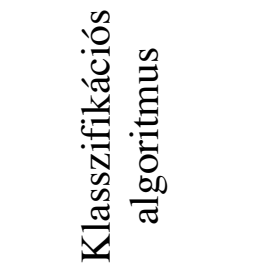 & 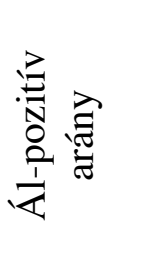 & 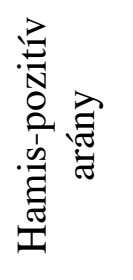 & 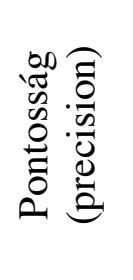 & 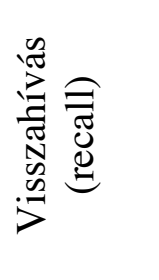 & 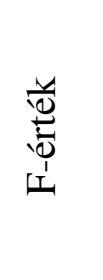 \\
\hline \multirow{6}{*}{ 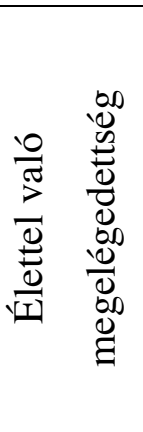 } & ZeroR & 0,853 & 0,853 & 0,728 & 0,853 & 0,785 \\
\hline & OneR & 0,824 & 0,855 & 0,724 & 0,824 & 0,770 \\
\hline & Naïve Bayes & 0,794 & 0,859 & 0,720 & 0,794 & 0,785 \\
\hline & $\mathrm{J} 48$ & 0,853 & 0,853 & 0,728 & 0,853 & 0,785 \\
\hline & RandomForest & 0,853 & 0,853 & 0,728 & 0,853 & 0,785 \\
\hline & RandomTree & 0,794 & 0,859 & 0,720 & 0,794 & 0,755 \\
\hline \multirow{6}{*}{ 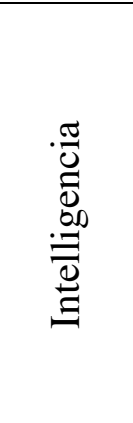 } & ZeroR & 0,853 & 0,853 & 0,728 & 0,853 & 0,785 \\
\hline & OneR & 0,824 & 0,858 & 0,724 & 0,824 & 0,770 \\
\hline & Naïve Bayes & 0,765 & 0,868 & 0,715 & 0,765 & 0,739 \\
\hline & $\mathrm{J} 48$ & 0,853 & 0,853 & 0,728 & 0,853 & 0,785 \\
\hline & RandomForest & 0,853 & 0,853 & 0,728 & 0,853 & 0,785 \\
\hline & RandomTree & 0,735 & 0,873 & 0,711 & 0,735 & 0,723 \\
\hline
\end{tabular}

27. táblázat: az intelligencia és az élettel való megelégedettség változókra alkalmazott klasszifikációs algoritmusok kimenete

A 27. táblázatból kitúnik, hogy a ZeroR, a J48 és a RandomForest algoritmus képes a legpontosabban előre jelezni az élettel való elégedettséget és az intelligenciát. Ezen algoritmusok a mintában szereplő példányok 85,3\%-ára helyes értéket adtak eredményül.

\subsubsection{Asszociáció}

A begyújtött 95 elemú mintára lefuttattam az Apriori algoritmust, annak érdekében, hogy szabályokat találjak a látogatókra jellemző személyes adatok és a személyre nem jellemző paraméterek között.

\section{Intelligencia}

Az algoritmus 18 ciklus után találta meg az elemzés további részéhez szükséges nagy adathalmazokat. A futtatások alkalmával a támogatottság (support) és a bizonyosság (confidence) értékei rögzítettek voltak. 


\begin{tabular}{|c|c|c|c|c|c|}
\hline & & \multicolumn{4}{|c|}{ Támogatottság/support } \\
\hline & & $\mathbf{0 , 1}$ & 0,2 & $\mathbf{0 , 3}$ & $\mathbf{0 , 4}$ \\
\hline \multirow{7}{*}{ 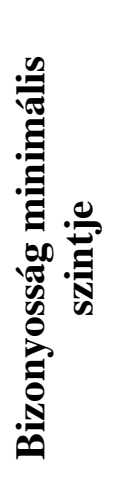 } & $\mathbf{0 , 1}$ & 0,34 & 0,34 & 0,31 & - \\
\hline & 0,2 & 0,34 & 0,34 & 0,31 & - \\
\hline & 0,3 & 0,34 & 0,34 & $\mathbf{0 , 3 1}$ & - \\
\hline & 0,4 & 0,45 & $\mathbf{0 , 4 5}$ & - & - \\
\hline & $\mathbf{0 , 5}$ & 0,54 & - & - & - \\
\hline & 0,6 & $\mathbf{0 , 6 7}$ & - & - & - \\
\hline & $\mathbf{0 , 7}$ & - & - & - & - \\
\hline
\end{tabular}

28. táblázat: a talált szabályok bizonyossági (confidence) szintje rögzített

bizonyosság és támogatottsági szint mellett

A 28. táblázatból kiolvasható, hogy a támogatottsági szint növekedésével a bizonyossági szint egyre csökken, tehát a megtalált szabályok a mintában szereplő egyének 10\%-ának intelligenciáját képesek 67\%-ban helyesen előre jelezni. Az algoritmus 768 szabályt talált 0,67-es bizonyossági szinten, amelyből mind szignifikáns. Ebből a két legrövidebb szabály az alábbiakban olvasható:

- Szabály 1

○ Windows 7 operációs rendszert használt

○ A képernyő szélessége nagyobb, mint 1024, de kevesebb, mint 1280

○ Egynél több földrajzi helyról érte el a weblapot

○ Legalább egyszer érte el a weblapot 18:00-23:00 óra között

○ Quicktime kiegészítő telepítve volt a látogató gépére

○ A használt böngészőnek volt PDF olvasási képessége

- Szabály 2

○ A képernyő szélessége nagyobb, mint 1024, de kevesebb, mint 1280

○ Egynél több földrajzi helyről érte el a weblapot

○ Legalább egyszer érte el a weblapot 18:00-23:00 óra között

○ Quicktime kiegészítő telepítve volt a látogató gépére

- Silverlight kiegészítő telepítve volt a látogató gépére

○ A használt böngészőnek volt PDF olvasási képessége

Mindkét esetében az intelligencia értéke 0,51 , ha a látogatóra igazak a felsorolt szabályok. A függelék 8.7.5 fejezetében olvasható képlet segítségével az IQ értéke 100,68 . 


\section{Élettel való elégedettség}

$\mathrm{Az}$ algoritmus ebben az esetben is 18 ciklus után találta meg nagy adathalmazokat, a támogatottság (support) és a bizonyosság (confidence) értékei szintén rögzítettek voltak.

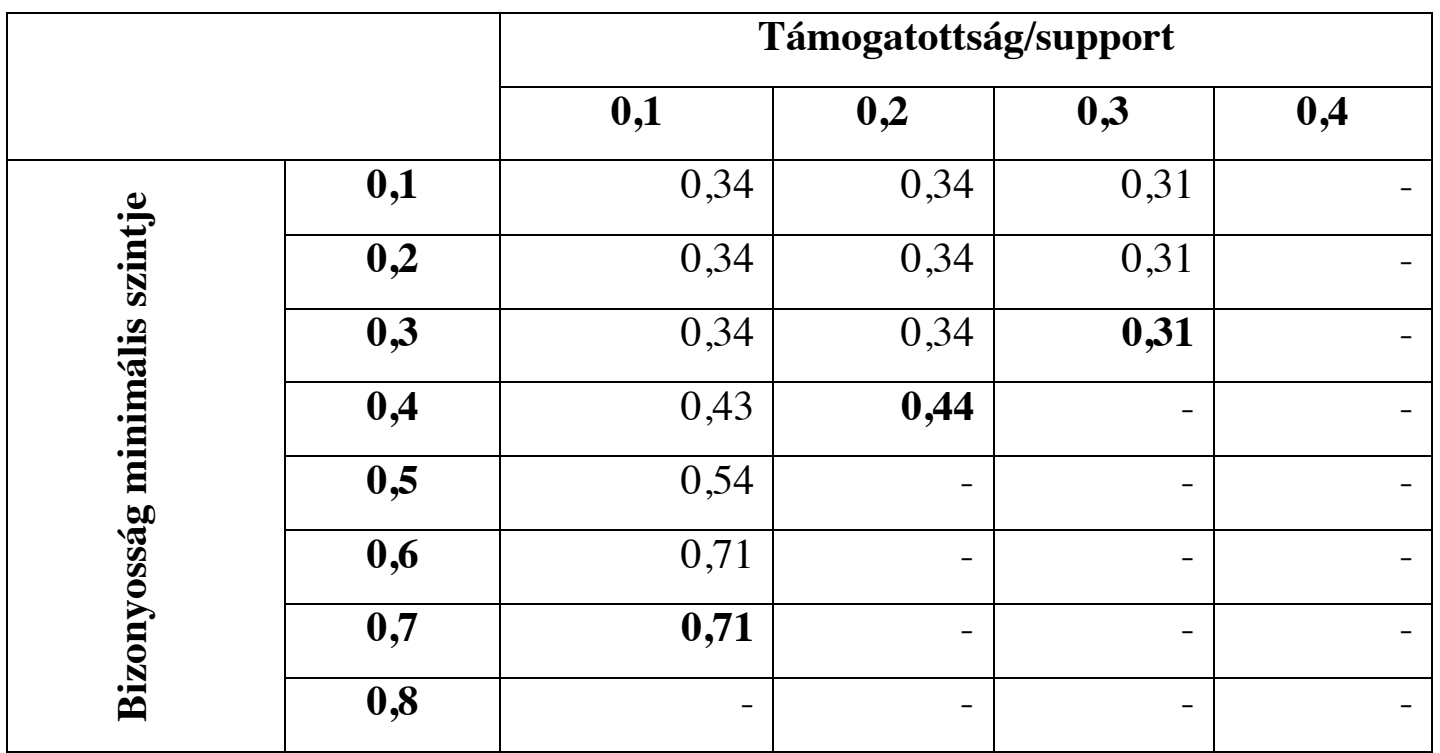

29. táblázat: a talált szabályok bizonyossági (confidence) szintje rögzített

bizonyosság és támogatottsági szint mellett

Az algoritmus 1024 szabályt talált a 0,71-es bizonyossági szint mellett, amelyek mindegyike szignifikáns volt. A legrövidebb szabály esetében az osztályváltozó értéke 0,32 vagy annál nagyobb:

- A képernyő szélessége nagyobb, mint 1024, de kevesebb, mint 1280

- Legalább egyszer érte el a weblapot 7:00-10:00 és 18:00-23:00 óra között

- Quicktime kiegészítő telepítve volt a látogató gépére

- A használt böngészőnek volt PDF olvasási képessége

\section{3. Összegzés}

A már korábban ismertetett a Budapesti Corvinus Egyetem polgárairól gyújtött mintában azt vizsgáltam, hogy lehetséges-e személyes tulajdonságokra vagy jellemzőkre következtetni a böngészés során elérhető nem személyes adatokból. A mintában kimutatható összefüggés található a böngésző személyisége és az általa használt szoftver és hardver környezet tulajdonságai, valamint a látogató online viselkedése között. 
Gyakori elemhalmazok részhalmazait kerestettem az adatbányász körökben népszerű Apriori algoritmussal, amelyek közül a magas konfidenciaszinttel és támogatottsággal rendelkezőket vizsgáltam. (Agrawal \& Srikant, 1994) Az algoritmus talált olyan szabályokat, amely a látogatók 10\%-a esetében 67\%-os konfidenciaszinten képes az intelligenciájukat, 71\%-os konfidenciaszinten pedig az élettel való elégedettségüket előre jelezni.

A talált szabályok nagy valószínúséggel csak a vizsgált mintára érvényesek, de megfelelően képesek a webes adatok adatbányászati algoritmusokkal történő potenciál érzékeltetésére. 


\section{UTÓHANG}

„... az internet, épp ahogy feltárta a világot mindenki számára, ugyanúgy tár fel mindnyájunkat a világ számára. És egyre inkább, a magánéletünk az ár, amit az összekapcsoltság miatt kell fizetnünk.”

Gary Kovacs, TED (Gary, 2012)

A dolgozatom alapvetően két részre osztható: az első, leíró részben az anonimitás fogalmát és a látogatók azonosításának és követésének módszereit járom körül bemutatva a témával kapcsolatos szakirodalmat. A webes böngészés alapjaitól kezdve rendszerezve írom le a látogatók azonosításának és követésének lehetséges módszereit. A második részben a témával kapcsolatos kutatásaimat írom le:

- Az eszközböngészókról begyújthetó adatok jellemzói címú kutatásban az egy domain alól elérhető weboldalak számára elérhető paraméterek csoportjait vizsgáltam, amelyek közül az egy átlagos munkamenet ideje alatt állandó paraméterek járultak hozzá legnagyobb mértékben a látogató beazonosításához. Tapasztalataim szerint minél több változót használok a felhasználó azonosításához, annál nagyobb vizsgálatba bevont változók együttes bizonytalanság eloszlató képessége. Ez azt jelenti, hogy egy ismert sokaság elemei közül nagy bizonyossággal be tudjuk azonosítani az egyén által használt eszközböngészőt, feltéve, hogy a munkamenet ideje alatt állandó paraméterei ismertek. Amennyiben meg szeretnénk nehezíteni a követőink dolgát, célszerú proxy-n keresztül minél kevesebb paramétert megosztani a követő weboldalak és harmadik felek számára.

- Az egyetemi polgárok pszichológiai jellemzói adatvédelmi szempontból címú kutatás során a - jelenleg legnépszerúbb közösségi oldal - a Facebook Likejait elemeztettem a University of Cambridge - The Psychometrics Centre munkatársai által kifejlesztett pszichológiai API segítségével. Az API az input adatokból képes érdeklődési kört, politikai beállítottságot, hitvallást, családi állapotot, szexuális orientációt és különféle személyiségi jellemzőket kinyerni. A saját és a myPersonality Project keretében gyűjtött mintán különféle klaszterképző eljárásokat futtattam, amelyek stabil klasztereket eredményeztek. A különböző forrású klaszterek közül 2 nagyon hasonló 
található: az egyedülálló, de nyitott, neurotikus és extrovertált tartalommegosztók és a komoly kapcsolatban lévő, kompromisszumképes, lelkiismeretes egyének.

- A Személyes információ kinyerése webes adatokból kutatásban szintén a Budapesti Corvinus Egyetem polgárairól gyűjtött mintában vizsgáltam a személyes tulajdonságok és a személyhez nem köthető, elérhető paraméterek közötti kapcsolatot. Kimutatható összefüggés található a böngésző egyén személyisége és az általa használt szoftver és hardver környezet tulajdonságai között. Ehhez a magas konfidenciaszinttel és támogatottsággal rendelkező gyakori elemhalmazok részhalmazait kerestettem az adatbányász körökben népszerú Apriori algoritmussal. (Agrawal \& Srikant, 1994) Az algoritmus talált olyan szabályokat, amely a látogatók 10\%-a esetében 67\%-os konfidenciaszinten képes az intelligenciájukat és 71\%-os konfidenciaszinten pedig az élettel való elégedettségüket előre jelezni.

Kutatásaim során egyaránt vizsgáltam a nem professzionális, egy domain alól elérhető weboldalak és professzionális a közösségi oldalak vagy hirdetési ügynökségek által hozzáférhetô adatokat. A kutatásaimból és a feldolgozott irodalomból levont konzekvenciákat a böngészés kiemelt aktorai számára az alábbiakban összegzem:

- Weboldalakat látogató egyének: az egy domain alól elérhető weboldalak számára viszonylag kevés információ érhető el, ebből korlátozottan, de lehetséges személyes jellemzők kinyerésére, a kinyilvánított preferenciák miatt a közösségi oldalak és a hirdetési ügynökségek által hozzáfért adatokból lehetséges a személyes jellemzőkre következtetni. Minél pontosabban ismert a látogató személyes jellemzői, annál jobban a látogatóhoz illeszkedő tartalmakat és reklámokat lehetséges küldeni számára, ami a „filter bubbles” jelenségéhez vezet. Ezt elkerülendő célszerū tudatosan használni a közösségi oldalakat, keresőmotorokat és minden olyan weboldalt, amelybe a hirdetési ügynökségek reklámhordozókat ágyaztak be.

- Adatvédelmi hatóság: az Európai Unió kiberbiztonsággal foglalkozó felelős szervezete a „European Union Agency for Network and Information Security” (ENISA), amelyet 2004-ben hoztak létre annak érdekében, hogy ajánlásokat 
tegyen, valamint a politikai szempontok kialakításánál és bevezetése során kulcsszerepet vállaljon az Európai Unió számára. (ENISA, 2017)

- Szoftverfejleszto//CIO: A felhasználói/látogatói viselkedés és preferenciákból történő azonosítás megelőzése miatt érdemes az alkalmazások felkészítése a tárolt információk fokozott védelmére. Fontos az ENISA által kiadott „,privacy by design" elv és a rá épülő keretrendszerek (ISO/IEC 29100) alkalmazása, amelynek célja az alkalmazások azok tervezési fázisában az információ védelmére való felkészítése. (Danezis, és mtsai., 2015)

A közösségi hálózatok megreformálták az információ terjesztését, hiszen használatukkal személyre szabott oldalon jelenik meg az ismerőseink által közzétett, az általunk kedvelt márkát és személyek által közzétett tartalmak. A Facebook népszerúségét jelzi, hogy a teljes emberi populáció közel 30\%-a csatlakozott már hozzá és az online megjelenő cégek és szervezetek mára már nem a saját weboldaluk internetes címével hirdetik magukat, hanem a közösségi oldalon használatos elérhetőségeikkel.

„Minden klikkeléssel és minden érintéssel a képernyön, olyanok vagyunk, mint Jancsi és Juliska és morzsákat hagyunk, személyes információ formájában, amint átkelünk a digitális erdőn keresztül.”

Gary Kovacs, TED (Gary, 2012)

Az online életünket körülvevő közösségi hálózatok rengeteg adatot gyűjtenek a webet használókról. Egyelőre szimbiózis tapasztalható a webet használó látogatók és a szolgáltatásaikat ingyen áruba bocsátó webhely tulajdonosok közt, és csak néhány esetben lehetett visszaéléseket tapasztalni. Mivel a korlátozó jogszabályok egyelőre még gyerekcipőben járnak, valamint az online alkalmazások jelentős része nincs megfelelően biztosítva adatszivárgás ellen, javasolt körültekintôen eljárni az adataink megosztása során. 


\section{FÜGGELÉK}

\subsection{HTML}

A weboldalak megjelenítését leíró nyelv a HTML azaz Hypertext Markup Language első verzióját Tim Berners-Lee alkotta meg a '90-es évek elején, de olyan gyorsan fejlődött, hogy 1997-ben már a HTML 4.0-ás verziójával találkozhatunk, majd 2008-ban publikálták a mérföldkőnek számító tervezetét, a HTML5-öt. 2012. decemberében W3C általi ajánlássá vált, majd 2014. októberében lett szabvány. Több új szintaktikai és szemantikai elemet tartalmaz és célja, hogy a desktop és a webes alkalmazások közti rést csökkentse.

A HTML kód legelső sora a DTD, (document type definition - dokumentum típus definíció) amely abban segít a böngésző számára, hogy az adott dokumentumot hogyan kell megjeleníteni. A DTD egy gép által olvasható nyelvtan, mely megadja a dokumentumban használható tag-ek listáját, valamint ezen tag-ekre érvényes szabályokat. Többek között a HTML alábbi verziói terjedtek el:

- HTML 4.01 (strict, transitional és frameset)

- XHTML 1.0 (strict, transitional és frameset)

- XHTML 1.1

- HTML5

A megfelelő DTD és az általa definiált szabályok használatával biztosíthatjuk, hogy a böngészők a tervezettnek megfelelően jelenítik meg a weboldalt.

\subsection{HTTP lekérdezés}

A szerveren található erőforrásokat URL-ek segítségével címezhetjük meg. Az URL a Uniform Resource Locator rövidítése és az erőforrások címzésére szolgáló protokoll, mely a 22. ábra, URL szerkezete látható módon épül fel. Az URL az URI (Uniform Resource Identifier - egységes erőforrás azonosító) családjába tartozik.

scheme://username:passwordedomain:port/path?query_string\#fragment_id

22. ábra, URL szerkezete (saját szerkesztés)

Az URL a lekérdezni kívánt erőforrás elérésének meghatározására használt cím. Tartalmazza a lekérdezéshez használt protokollt, a szerver IP címét vagy domain-jét, a kommunikációhoz használt port számát, a lekérdezni kívánt erőforrás szerveren belüli helyét és a query stringet. A query string az URL-ben a ? után következő rész 
adatok átküldésére szolgál, kulcs-érték párok formájában, egymástól \& jellel elválasztva. Végül a \# jel az oldalon belüli pozícionálás miatt szükséges.

A DNS feloldást követően a böngésző HTTP lekérdezéseken keresztül kommunikál a webszerverrel. A HTTP protokoll kapcsolat nélküli, ez azt jelenti, hogy a lekérdezés elküldését követôen lecsatlakozik a szerverről és vár a válaszra.

\section{The HTTP Request}

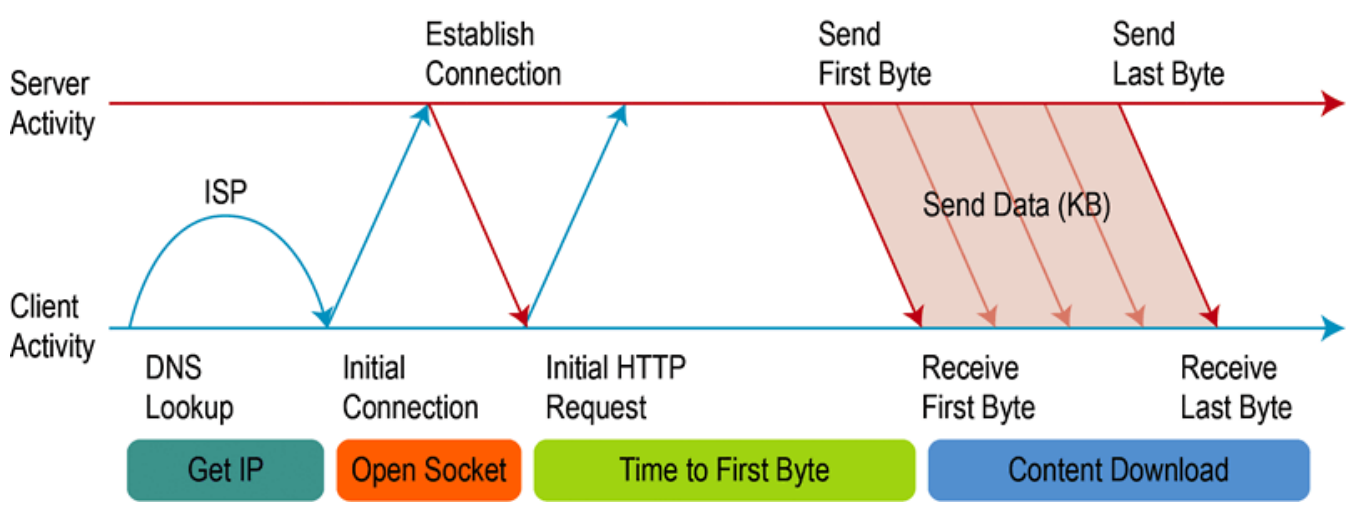

23. ábra, A HTTP lekérdezés menete (Websiteoptimization.com, 2009)

A szerverről letölteni kívánt eróforrások lehetnek statikusak vagy dinamikusak. A statikus erőforrások tipikusan file-ok a szerveren, melyek tartalma nem vagy csak ritkán módosul. A dinamikusan előállított tartalmak előállításához a webszerver általában egy külső programozási nyelvhez fordul, ami minden alkalommal előállítja azt (kivétel persze, ha egy dinamikusan előállított tartalmat cache-elünk), majd visszaadja azt.

Amennyiben a HTTP lekérdezés egy erőforrásra hivatkozik, a szerver az alábbiak szerint járhat el:

- amennyiben a lekérdezni kívánt erőforrás egy a szerveren tárolt statikus file-ra vonatkozik, akkor a HTTP válaszban a szerver visszaküldi azt a kliens számára

- ha a kérés egy dinamikusan létrehozott HTML állományra hivatkozik, akkor a webszerver egy szerveroldali nyelvhez fordul, amelynek a outputja lesz az a HTML tartalom, amelyet a kliens számára visszaküldve annak böngészóje megjelenít.

A letölteni kívánt állomány/erőforrás állapotáról a webszerver hibakódok segítségével kommunikál a klienssel, amely a HTTP protokoll része. Néhány gyakran előforduló HTTP hibakód: 
- 200 ,Success”: sikeresen teljesítve, a válasz üzenet törzsében található a szerver által generált output

- 301 ,Moved permanently”: a kívánt erőforrást áthelyezték, a válaszból megtudható, hogy hova

- 404 „Not found”: a kívánt erőforrás nem található

- $\quad 500$ „Internal server error”: általános hibaüzenet, többnyire a szerveren futó meghívott alkalmazás hibát dobott

A HTTP protokoll többféle metódussal teszi lehetővé egy állomány lekérdezését. A weblapok és online ûrlapok túlnyomó többsége a lentebb kifejtett GET és POST metódust használja az összes múvelet elvégzésére, azonban a HTTP 1.1 protokoll több lekérdezési metódust (Dan, 2004) támogat:

- GET: adat lekérdezésére szolgáló metódus. A lekérdezés paraméterei a query stringben lesznek elküldve. Az URL legnagyobb megengedett hossza 1024 byte, így a query string emiatt nem lehet túl hosszú, valamint érzékeny adatok átküldésére nem célszerú használni.

- HEAD: ugyanaz, mint a GET, csak ebben az esetben a szerver csak a fejlécet küldi vissza (response header)

- POST: adat küldésére szolgáló metódus. A lekérdezés testében (body) van a szerverre küldött adat. (szöveg, adatállomány stb.)

- PUT: adat megváltoztatására vagy létrehozására szolgáló metódus

- DELETE: adat törlésére szolgáló metódus

- OPTIONS: kommunikációval kapcsolatos információk lekérdezésére szolgál

- TRACE: visszaküldi a kliens számára az elküldött üzenetet. Annak tesztelésére találták ki, hogy a kliens és a szerver között lévő csomópontok mit változtatnak meg az elküldött adatcsomagban.

- CONNECT: TCP/IP tunnel-lé változtatja a kommunikációs kapcsolatot, így lehetőség nyílik HTTPS kapcsolatra HTTP-t támogató proxy-n keresztül is.

- PATCH: az elküldött adatok csak egy része a rekordnak, módosításra használható

A GET és a POST metódus idempotens, a HEAD, OPTIONS, GET és a TRACE metódus biztonságos, mivel az nem végez módosítást a szerveren. 


\begin{tabular}{|l|l|}
\hline \multicolumn{1}{|c|}{ GET } & \multicolumn{1}{c|}{ POST } \\
\hline GET /blog/?name1=value1\&name2=value2 & POST /blog/HTTP/1.1 \\
HTTP/1.1 & Host: carsonified.com \\
Host: carsonified.com & name1=value1\&name2=value2 \\
\hline
\end{tabular}

30. táblázat: A GET és POST lekérdezés HTTP fejléce (saját)

Az adatok tárolásánál 4 alapmúveletet szoktak megkülönböztetni: létrehozás, olvasás, módosítás és törlés. Az adatbázis múveletek is eszerint csoportosíthatóak és a fent említett metódusok szintén megfeleltethetőek a 4 alapmúveletnek az alábbiak szerint:

\begin{tabular}{|l|l|l|}
\hline \multicolumn{1}{|c|}{ Múvelet } & \multicolumn{1}{c|}{ SQL } & \multicolumn{1}{c|}{ HTTP } \\
\hline Create & INSERT & PUT/PATCH \\
\hline Read (retrieve) & SELECT & GET \\
\hline Update (Modify) & UPDATE & POST \\
\hline Delete (Destroy) & DELETE & DELETE \\
\hline
\end{tabular}

31. táblázat: az SQL és a HTTP CRUD múveletei (Medic, 2014)

Miután a böngésző megkapta a választ a szervertól, elkezdi annak feldolgozását. Ha a HTTP válasz fejlécében érkezik süti, akkor azt a böngésző létrehozza. A 24. ábra a WizzAir.hu webhely lekérdezésére irányuló HTTP válasz látható. A Set-Cookie rész első két sorában látható két munkamenet azonosító, majd látható a Culture nevú változóba elmentették a lokalizációt. A süti lejárati ideje 1 év és az egész webhelyre érvényes.

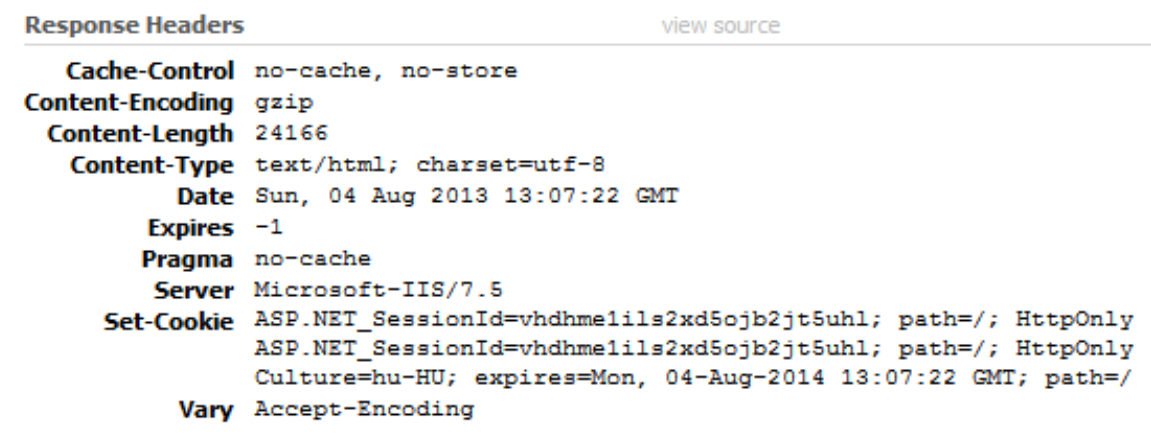

24. ábra, a WizzAir.hu föoldalának HTTP válasza (saját) 
Ha a feldolgozandó adat egy HTML állomány, akkor értelmezi azt, letölti a külső hivatkozásokat, majd elkezdi kirajzolni a dokumentumot és ahol Javascriptet talál, azonnal elkezdi futtatni, ez akkor is megtörténik, ha a dokumentum bizonyos részei még nem töltődtek le. Erre a problémára a megoldás, ha figyelünk valamilyen betöltődés/feldolgozás vége eseményre.

A dokumentum rajzolásának végén két fontos esemény hívódik meg:

- onDomReady: akkor hívódik meg, ha a memóriában már rendelkezésre áll a DOM, tehát bármelyik része hivatkozható, módosítható és törölhetô, viszont a külső erőforrások (CSS, képek, iframe-ek tartalma stb.) még nem feltétlenül állnak rendelkezésre

- onLoad: akkor hívódik meg, ha az egész dokumentum letöltődött a DOM rendelkezésre áll a memóriában, valamint letöltődött az összes külső erőforrás is

Az alap Javascriptben csak az onLoad esemény létezik az onDomReady nem, így azt csak különböző library-k vagy framework-ök segítségével lehet csak elérni. A Javascript futtatásához nem szükséges megvárni, hogy az összes kép vagy stíluslap letöltődjön, ha a memóriában rendelkezésre áll a DOM, el lehet kezdeni a Javascript futtatását.

Az AJAX az Asynchronous Javascript and XML rövidítése, amely webes technológiák csoportját foglalja magába. Tulajdonképpen adatok küldése és fogadása a szervertől az oldal újratöltése nélkül. A kérést Javascript indítja el a háttérben és aszinkron ${ }^{29}$ módon vár a válaszra.

\subsection{Javascript}

Jelenleg a Javascript/ECMAScript ${ }^{30}$ az egyetlen, amelyet az összes böngésző támogat. A nyelvet eredetileg a webböngészőkbe tervezték, hogy elősegítse a RIA-k létrejöttét, (rich internet application) interaktívvá tegye a weblapokat vagy képessé tegye a böngészőt aszinkron kommunikációra.

A DOM (Document Object Model) egy platform és nyelvfüggetlen konvenció, HTML, XHTML és XML dokumentumokkal való interakcióra és adatok

\footnotetext{
${ }^{29}$ a kérés elküldése és a válasz visszaérkezése között eltelt idő alatt is fut tovább az alkalmazás, azaz nem akadályozza annak futását

${ }^{30}$ A Netscape kezdeményezésére 1997-ben fogadta el az ECMA (European Computer Manufacturers Association) ECMAScript néven
} 
megjelenítésére alkalmas. A DOM fa struktúrában tárolt és az egyes elemek a saját függvényeikkel címezhetőek és manipulálhatóak. Ez tulajdonképpen a böngésző APIja.

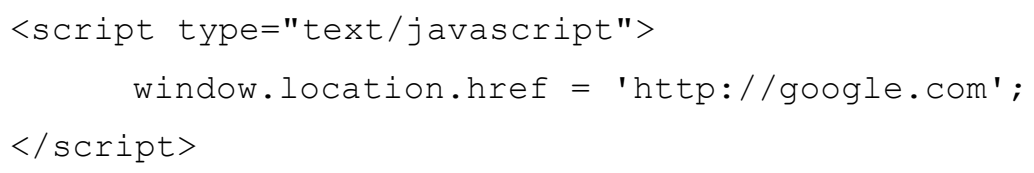

25. ábra, HTML DOM objektum kezelése Javascript-tel (saját szerkesztés)

\subsection{Süti (cookie)}

A süti (cookie) egy kliensoldali adattárolási módszer neve. A böngésző a kliens oldalon egy kódolatlan szöveges állományban kulcs-érték párok formájában tárolja el a kívánt adatokat. Az eltárolható sütik maximális mérete $4 \mathrm{kB}$, de ez az érték böngészőnként eltérhet, valamint domain-enként maximálisan 50 sütit lehet eltárolni. A kliens hardverére telepített különböző böngészők nem képesek olvasni és írni egymás sütijeit. Ez azért fontos tényező, mert egy felhasználó által használt hardveren a különböző böngészők nem férnek hozzá egymás sütijeihez, így ha a sütiket a felhasználó követésére használjuk, ha a felhasználó böngészőt vált, beazonosítása nehézkessé válik.

A sütik létrehozásánál megadható a lejárati idejük, amely lejárta után a süti a böngésző által már nem hozzáférhető. A süti törléséhez így csak egy múltbeli időpontra kell állítani a lejárati idejét. Amennyiben nem adunk meg lejárati időt, a süti a munkamenet lejártakor törlődik.

A süti létrehozásakor megadhatjuk annak láthatósági/hozzáférhetőségi körét. Alapesetben a süti mindig csak az adott domain és az URL-ben lévő elérési út számára elérhetô. Szükség esetén feloldható ez a korlátozás oly módon, hogy az adott domainen lévő más weboldal is hozzáférhessen. Természetesen egy adott domain alól más domain számára nem hozható létre süti.

A sütiket az alábbi módokon lehet létrehozni:

- a szerveroldali nyelv a HTTP válaszban küldi azt, a böngészó pedig létrehozza a kulcs-érték párokat tartalmazó file-t a kliens eszközén. A 26. ábra látható, hogy a HTTP válasz fejlécében a Set-Cookie paraméter tartalmazza a sütiben eltárolandó kulcs-érték párokat 


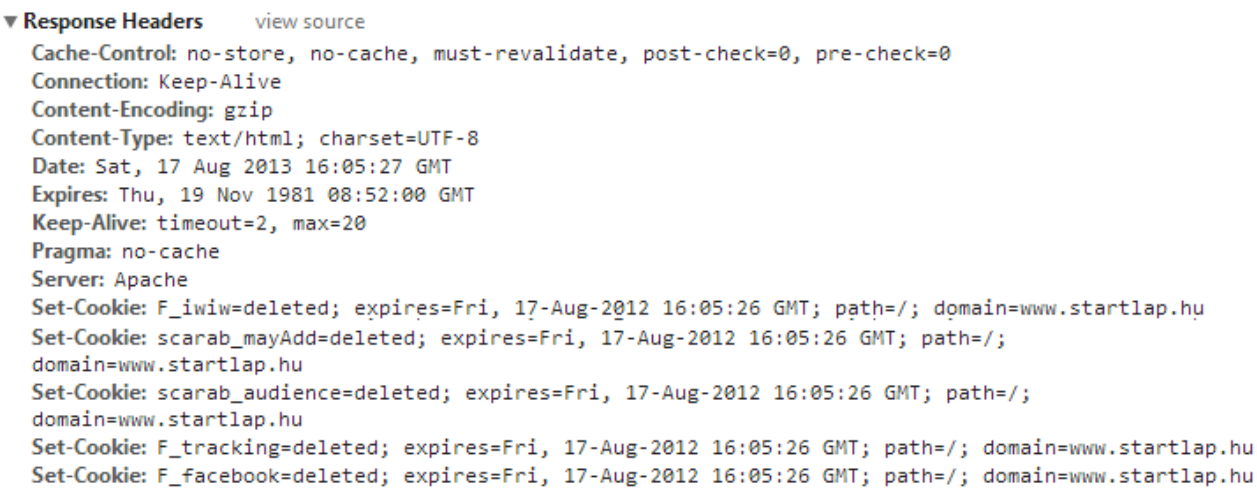

26. ábra, szerver által küldött sütik (saját felvétel)

- a kliensoldali programozási nyelv utasítja közvetlenül a böngészőt a süti létrehozására. A 27. ábra látható, hogy az alap Javascripttel magunknak kell összeállítani a kulcs-érték pár, valamint a hozzá tartozó lejárati időt, míg jQuery esetében paraméterként adjuk át a kulcsot és az értéket, az extra paramétereket pedig objektumként

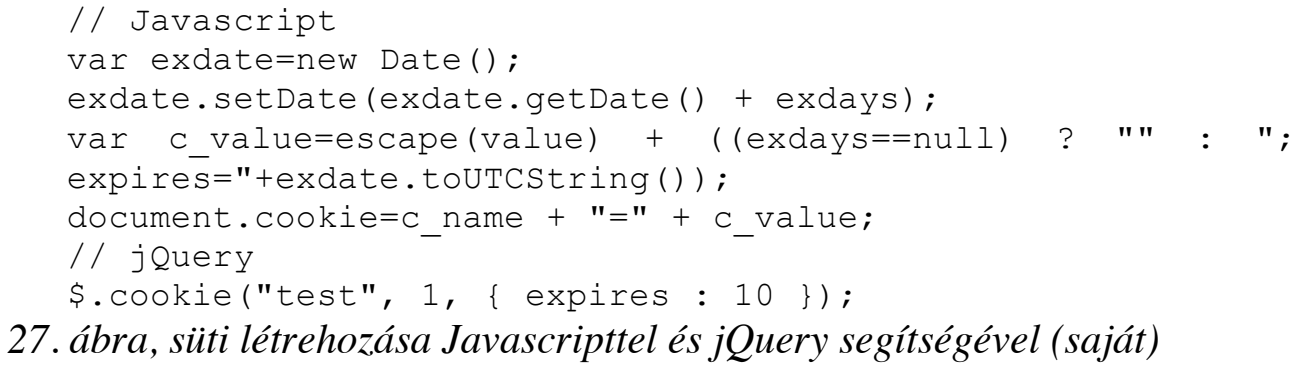

$\mathrm{Az}$ adott domain által létrehozott süti tartalmát a böngésző minden egyes lekérdezés során a HTTP fejlécben elküldi a szerver számára, így ha a sütiben sok adatot tárolunk, akkor azok minden egyes lekéréssel együtt el lesznek küldve a szerverre pazarolva a sávszélességet. Az esetek többségében (képek, CSS, Javascript állományok, statikus tartalmak stb.) ezek az adatok teljesen feleslegesen lesznek elküldve a szerverre. Ilyen esetekben szokták azokat az erőforrásokat, amelyekhez nincs szükség sütire, kitenni egy cookie mentes domainre, aldomainre vagy CDN-re ${ }^{31}$. A céljuk és a felhasználási módjuk alapján az alábbi sütiket különböztetjük meg:

\footnotetext{
${ }^{31}$ A Content Delivery Network (CDN) a webes tartalomelosztás egyik módszere. A lényege, hogy a tartalmat a Föld különböző pontjain helyezik el redundásan és az igény felmerüléséhez legközelebbi csomópont szolgál ki.
} 
- Munkamenet süti: nincs beállítva a lejárati idejük, így csak addig léteznek, amíg a felhasználó be nem zárja a böngészőjét

- Perzisztens/nyomkövető süti: a munkamenet lejártát vagy a böngésző bezárását követôen nem törlődnek a felhasználó gépérôl, a lejárati idejük egy konkrét időpontra van beállítva. A beállított időpontig minden egyes lekéréssel a HTTP fejlécben el lesznek küldve a szerverre.

- 3rd party cookie/3. fél által készített süti: általában hirdetők által alkalmazott technológia, az adott weboldal meglátogatása során a lekérdezett weboldaltól különböző domain alá elhelyezett süti. A sütik forrás domain-je nem egyezik meg a megtekintett oldal domain-jével, emiatt könnyú azokat kiszúrni. DNS aliasing technológiával a harmadik fél által használt domain egy DNS CNAME alias-szal átirányítható a meglátogatott oldal domain-jére, így azok kiszúrése nem lehetséges. (Chris, Ashkan, Nathaniel, \& Dietrich, 2012)

A sütik kis méretük (maximálisan $4 \mathrm{kB}$ ) ellenére igen sokoldalúan felhasználhatóak, többek között munkamenet kezelésére, a weboldal személyre szabásra és felhasználói élmény növelésére, valamint nyomkövetésre.

A törvény, amely a sütiket és más kliensoldali adattárolási technológiákat szabályoz 2011. május 26-án lépett hatályba Európában, (All About Cookies, 2011) kötelezi a weboldalak készítőit, hogy mielőtt sütiket mentenének a kliens böngészőjébe, előzőleg engedélyt kell kérni a felhasználótól. (opt-in)

A sütikben a weboldal tetszőleges adatot tárolhat. Érzékeny adatokat nem célszerú benne tárolni, mivel az kódolatlan állományként tárolódik a kliens gépén. A süti megtartja az értékét mindaddig, amíg az alábbi események valamelyike be nem következik:

- A süti érvényessége lejár: a lejárati dátuma korábbi, mint az internetezéshez használt eszközről kiolvasható időpont, ebben az esetben a böngésző a következő futása alkalmával az internetezéshez használt eszközről is törli a sütit tartalmazó állományt, így az a továbbiakban nem lesz olvasható.

- A süti tartalma nem olvasható: a böngésző számára nem hozzáférhetô a süti tartalma, mert az file szinten nem hozzáférhető. Ennek az is lehet az oka, hogy a sütik tartalmát szándékosan törölték vagy olvashatatlanná tették az internetezéshez használt eszközről. 


\subsection{CSS3 és HTML5 képességek}

- CSS3 képességek - Javascript segítségével detektálhatóak

○ @font-face, background-size, border-image, border-radius, boxshadow, flexible box model - különböző CSS3 képességek

○ hsla - hue-saturation-light-alpha színpaletta használata

○ több háttérkép használatának lehetősége

○ rgba - piros-zöld-kék-alpha színskála használatának lehetôsége. A CSS korábbi verziói csak az RGB színskálát támogatták, az RGBA esetében lehetőség nyílik az áttetszőség megadására is. Ez akkor lehet hasznos, ha az aktuális elem mögött még van valamilyen többszínú vizuális elem.

○ text-shadow - szöveg árnyékolásának lehetősége

○ CSS animáció lehetősége - a kijelölt elemek animálásának lehetősége

○ hasábok létrehozásának lehetôsége - lehetséges-e CSS-ből hasábokra bontani egy szöveget

○ generated content (:before/:after) - CSS segítségével a kijelölt elem elé illetve mögé lehet beszúrni tartalmat

○ CSS gradients - CSS szinátmenet képzésének lehetősége

○ CSS tükröződés - egy elem tükröződésének beállításának lehetősége

- CSS 2D transzformáció támogatása

- CSS 3D transzformáció támogatása

- CSS transitions/átmenetek (transitions) - az animáció és az átmenet között az a különbség, hogy amíg az animáció folyamatos, az átmenetet valamilyen eseményhez kötött, pl: kattintás stb.

- HTML5 képességek - szintén Javascript segítségével detektálhatóak

○ applicationCache - alkalmazás cache támogatása

○ canvas - grafikák rajzolásának lehetősége tag-ekkel vagy Javascriptből

○ canvastext - szöveg írása a festővászonra

○ Drag and Drop támogatása - drag and drop események támogatása, lehetőség van az asztalról file-ok beemelésére, valamint a böngészőből file-ok és tartalmak kiemelésére

○ hashchange esemény támogatása - akkor következik be, ha a meglátogatott URL hashtag mögötti része megváltozik 
○ history - history management támogatása

○ audio - ogg, mp3, wav és m4a audiofile-ok lejátszásának támogatása

○ video - ogg, webm és h264 formátumú videofile-ok lejátszásának támogatása

○ indexedDB - indexedDB kliensoldali adattárolás támogatása

○ beviteli mező attribútumok (autocomplete, autofocus, list, placeholder, max, min, multiple, pattern, required, step) támogatása

○ beviteli mezó típusok (search, tel, url, email, datetime, date, month, week, time, datetime-local, number, range, color) támogatása

- localStorage és sessionStorage támogatása

○ postmessage - ablakok közti kommunikáció támogatása

○ webSockets - socket kommunikáció támogatása

○ webSQLDatabase - kliensoldali SQL adatbázis támogatása

○ webWorkers - többszálúság támogatása

○ geoLocation - geolocation támogatása

- SVG és inline SVG - Scalable Vector Graphics támogatása

- SVG clip paths - SVG rajzolás során alkalmazható clipPath, ami azt jelenti, hogy a rajzolási terület

○ SMIL - Synchronized Multimedia Integration Language támogatása, multimédiás előadások készíthető vele

○ touch - érintőképernyő támogatása

○ webGL - rajzolásoz használt API támogatása

- A kliens oldal terhelését követően pedig a szerver oldal terhelését elemzem ugyanolyan szempontok szerint.

\subsection{Látogatók azonosításához használható kiemelt paraméterek elemzése}

\begin{tabular}{|c|c|c|}
\hline Megnevezés & Előny & Hátrány \\
\hline IP cím & $\begin{array}{l}\text { - } \text { dinamikus IP cím } \\
\text { esetében a } \\
\text { munkamenet } \\
\text { idejére azonosítja } \\
\text { az } \\
\text { eszközböngészőt } \\
\text { - fix IP cím } \\
\text { esetében akár }\end{array}$ & 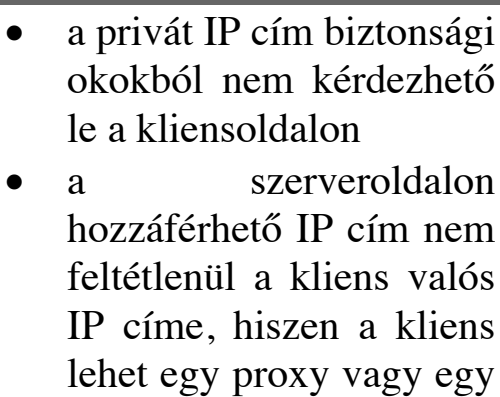 \\
\hline
\end{tabular}




\begin{tabular}{|c|c|c|}
\hline & $\begin{array}{l}\text { hosszabb idön } \\
\text { keresztül, több } \\
\text { munkamenet } \\
\text { idejére azonosítja } \\
\text { az } \\
\text { eszközböngészőt }\end{array}$ & $\begin{array}{l}\text { router mögött is, amely } \\
\text { elfedi az IP címét } \\
\text { - geoLocation hiányában } \\
\text { az IP címből lehet } \\
\text { feloldani földrajzi } \\
\text { pozíciót }\end{array}$ \\
\hline $\begin{array}{l}\text { Képernyő } \\
\text { magassága / } \\
\text { szélessége és } \\
\text { bitmélység }\end{array}$ & 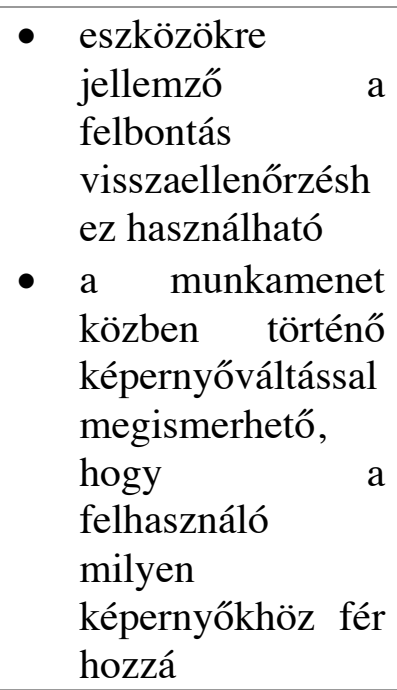 & $\begin{array}{l}\text { - a felhasználó } \\
\text { munkamenet közben is } \\
\text { válthat képernyőt, így } \\
\text { ezek az adatok menet } \\
\text { közben is változhatnak }\end{array}$ \\
\hline $\begin{array}{l}\text { Aktuális } \\
\text { böngészőablak } \\
\text { mérete }\end{array}$ & & $\begin{array}{l}\text { - felhasználó akármikor } \\
\text { megváltoztathatja, } \\
\text { felesleges lementeni }\end{array}$ \\
\hline Useragent string & $\begin{array}{l}\text { - minimum a } \\
\text { munkamenet } \\
\text { idejére azonosítja } \\
\text { az } \\
\text { eszközböngészőt } \\
\text { - értékes } \\
\text { információval } \\
\text { szolgál a kliens } \\
\text { böngészőjéről, } \\
\text { operációs } \\
\text { rendszeréről és } \\
\text { hardveréről }\end{array}$ & $\begin{array}{l}\text { - a Useragent string sűrún } \\
\text { változhat, akár havonta is } \\
\text { frissítheti a böngészójét a } \\
\text { felhasználó }\end{array}$ \\
\hline $\begin{array}{l}\text { HTML5 \& CSS3 } \\
\text { képességek }\end{array}$ & $\begin{array}{l}\text { - UX szempontból } \\
\text { lehet érdekes }\end{array}$ & $\begin{array}{l}\text { - böngésző típus és } \\
\text { verzióra jellemző }\end{array}$ \\
\hline $\begin{array}{l}\text { Beépüló modulok } \\
\text { jelenléte és } \\
\text { verziószáma }\end{array}$ & 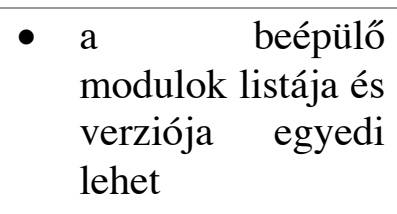 & \\
\hline $\begin{array}{l}\text { Telepített } \\
\text { betútípusok }\end{array}$ & $\begin{array}{ll}\text { - } & \text { a telepített } \\
\text { betúkészletek } \\
\text { listája egyedi } \\
\text { lehet }\end{array}$ & $\begin{array}{l}\text { - Flash beépülő modul } \\
\text { nélkül nem lehet } \\
\text { lekérdezni }\end{array}$ \\
\hline
\end{tabular}




\begin{tabular}{|c|c|c|}
\hline & $\begin{array}{l}\text { - inputként } \\
\text { szolgálhat } \\
\text { telepített } \\
\text { szoftverek } \\
\text { listájához }\end{array}$ & $\begin{array}{l}\text { - Flash } \quad \text { blokkoló } \\
\text { alkalmazás jelenlétével } \\
\text { nem állítható eló }\end{array}$ \\
\hline Hálózat típusa & $\begin{array}{l}\text { - értékes } \\
\text { információval } \\
\text { szolgál a } \\
\text { felhasználó } \\
\text { internetkapcsolatá } \\
\text { ról }\end{array}$ & 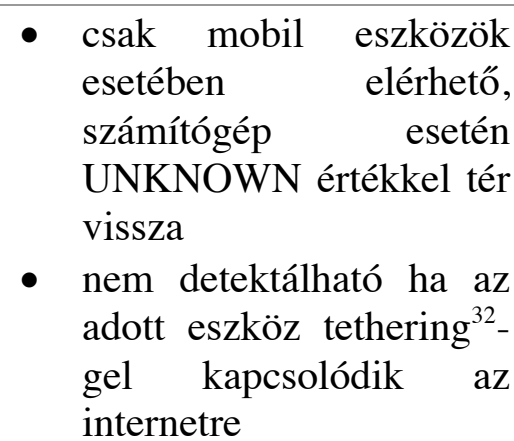 \\
\hline $\begin{array}{l}\text { Felhasználó } \\
\text { böngészési } \\
\text { előzménye }\end{array}$ & $\begin{array}{l}\text { - a böngészőből } \\
\text { biztonsági okok } \\
\text { miatt nem érhetô } \\
\text { el } \\
\text { - } \\
\text { szerveroldalon a } \\
\text { felhasználó } \\
\text { elmentett } \\
\text { felhasználó } \\
\text { böngészési } \\
\text { elózményeiből } \\
\text { lekérdezhető }\end{array}$ & $\begin{array}{l}\text { - megtudható belóle, hogy } \\
\text { a felhasználók a webhely } \\
\text { mely részeit nézik } \\
\text { gyakrabban }\end{array}$ \\
\hline Oldalletöltés ideje & 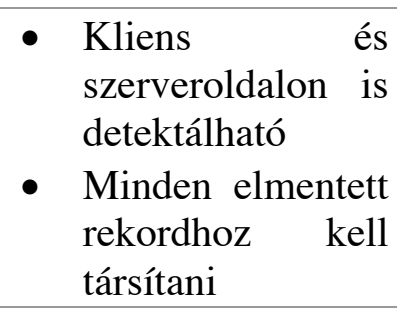 & \\
\hline $\begin{array}{l}\text { Generált } \\
\text { eszközböngésző } \\
\text { azonosító }\end{array}$ & $\begin{array}{l}\text { - } \text { egyértelmüen } \\
\text { azonosítja az } \\
\text { eszközböngészőtt }\end{array}$ & $\begin{array}{l}\text { - a felhasználó } \\
\text { módosíthatja } \\
\text { törölheti }\end{array}$ \\
\hline $\begin{array}{l}\text { Billentyúzet és } \\
\text { egérhasználat }\end{array}$ & $\begin{array}{l}\text { - Felhasználóra } \\
\text { jellemző }\end{array}$ & 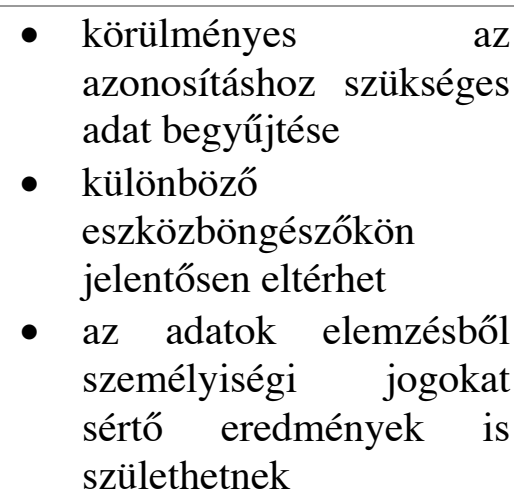 \\
\hline
\end{tabular}

32. táblázat: kiemelt paraméterek elemzése

32 internet megosztása mobil eszközön keresztül 
8.6.1. HARDVER JELLEMZÖI

- Hálózat típusa (ethernet, 3G, Wifi stb.): mobil kommunikációs eszközök esetében Javascript segítségével elérhető

- Eszköz típusa, verziója: szintén a HTTP lekérdezés fejlécében található Useragent string-ből kinyerhető

- Képernyő szélessége és magassága, megjelenítéshez használt bitmélység: csak a kliensoldalon áll rendelkezésre, Javascript segítségével lekérdezhető

8.6.2. OPERÁCIÓS RENDSZER, SZOFTVERKÖRNYEZET JELLEMZŐI ÉS HÁLÓZATI JELLEMZÖK

- Csatlakozáshoz használt ISP adatai: online adatbázisok adatbázisokból kinyerhető információ, sok esetben kikövetkeztethető belőle a kapcsolat típusa is, ha tudjuk, hogy az adott ISP milyen kapcsolatot szolgáltat. Van olyan szolgáltató, amely csak vezetékes internetet és van olyan is, amelyik csak mobilinternetet szolgáltat.

- Operációs rendszer típusa és verziószáma: a HTTP lekérés fejlécében lévő User-agent string-ből kinyerhető

- IP cím: a szerveroldalon környezeti változóként rendelkezésre áll

- Host: az IP címből reverse DNS-sel visszafordítható

- geoLocation szélességi és hosszúsági fok, pontosság - Javascript segítségével kérdezhető le a böngészőből, felhasználói beleegyezés szükséges

- Telepített betútípusok: a kliensoldalon érhető el Flash kiegészítő használatával

- Telepített alkalmazások: a telepített betútípusok jellemzőek lehetnek egy-egy alkalmazásra, a telepített betútípusok elemzéséből következtetni lehet a látogató gépére telepített alkalmazásokra. Problémát jelenthet az alkalmazások telepítésekor feltelepített betútípusok listájának összegyújtése, valamint a lista frissen tartása.

\subsubsection{ESZKÖZBÖNGÉSZŐ JELLEMZŐI}

- Böngésző típusa és verziószáma: szintén a HTTP lekérdezés fejlécében lévő User-agent string-ből kinyerhető 
○ httpUserAgent - a böngészó és operációs rendszer adatait tartalmazó szöveg

○ httpAccept - a böngésző által támogatott állományok MIME típusa

○ httpAcceptEncoding - a böngésző által támogatott tömörítési típusok és prioritásuk

○ httpAcceptLanguage - a böngésző által támogatott nyelvek és prioritásuk

○ httpAcceptCharset - a böngésző által támogatott karakterkódolások és prioritásuk

○ Do-not-Track: a HTTP lekérdezés fejlécéből kinyerhető paraméter

- CSS3 és HTML5 képességek (lásd a Függelékben)

- Beépülō modulok jelenléte és jellemzői

- Flash verziója, Flash blokkoló múködik-e, Silverlight verziója, Quicktime verziója, DevalVR verziója, Shockwave verziója, Windows Media Player verziója, Java verziója, PDF olvasó van-e a böngészőben, Adobe PDF Reader verziója, VLC Player verziója, Firefox PDF reader verziója, RealPlayer verziója

- Felhasználó böngészési előzménye - a felhasználó böngészési előzménye, a böngészési előzmény nem hozzáférhető, azonban a szerveren környezeti változóként elérhető a hívó URL ${ }^{33}$ (referrer) (Jia-Ching, Chu-Yu, \& Vincent, 2012)

- Inkognitó mód használata: kliensoldalon keresztül volt érhető el Javascript segítségével, az új böngészőkben nem lehet detektálni

- generált eszközböngésző azonosító - a szerveroldalon a böngésző jellemzőiből generált adat, amely az eszközböngésző nyomkövetésére alkalmas, a kliensoldalon sütiben és amennyiben lehetséges, akkor localStorage-ben tárolódik, a szerveroldalon pedig célszerú adatbázisban eltárolni

- Közösségi hálózatok által hozzáférhető adatok - harmadik féltől hozzáférhető adat, amely a szerver és a kliens oldalon is lekérdezhető. A lekérdezést célszerú a szerveroldalra helyezni, mivel a túl sok adat egyidejű

\footnotetext{
${ }^{33}$ Amennyiben a nyomkövető kódot az oldalon belül egy iframe-ben helyezzük el, a referrer értéke a maga a meglátogatott weblap lesz
} 
lekérdezése csökkentheti a böngészési élményt. Egyszeri elhasználói beleegyezés szükséges, és pl: a Facebook esetében időközönként meg kell újítani az engedélyt.

○ OpenID

○ Facebook azonosító és az összes Facebook-on tárolt adat

○ Google+ azonosító és az összes Google+-on tárolt adat

○ LinkedIn azonosító és az összes LinkedIn-en tárolt adat

○ egyéb közösségi hálózatokon tárolt és lekérdezhető adat

\subsubsection{LÁTOGATÓ JELLEMZŐI}

- egy meglátogatott webhely bejárásának módja - a lementett adatokból kinyerhető

- egérmozgás (x és y koordináta és időpont) - a kliensoldalon detektálható Javascript segítségével

- billentyúzet leütés (billentyú lenyomása és felengedése, időpont) - Javascript segítségével detektálható a kliensoldalon

A lista nem teljes, egy jelenkori állapotot tükröz, és jól szemlélteti, hogy a böngészőkből milyen mennyiségű adat hozzáférhető és ennek nagy része akár már 1 oldal meglátogatásával is hozzáférhető. A 2012 tavaszán elvégzett adatgyújtési kísérletem során a felhasználók átlagosan 300 kB adatot osztottak meg magukról és egy oldal letöltésével több, mint 4 kB-ot.

\subsection{Adatgyújjtő alkalmazás}

A fejezet az általam fejlesztett adatgyújtő alkalmazás dokumentációját tartalmazza. A 4.2 Az adatgyújtés fejezetben kifejtettem az alkalmazással szemben felállított követelményeimet, valamint a saját alkalmazás fejlesztésének indoklását. Miután az Budapesti Corvinus Egyetem Informatika Intézetének vezetésétól megkaptam az engedélyt, hogy az Egyetem e-learning rendszerébe beépítsem az adatgyưjtő alkalmazást felmértem az adatgyűjtő alkalmazás beépítésének lehetôségeit. Ennek eredményeképpen a bejelentkezést követően az alkalmazás egy iframe-en belül jelenik meg az oldal tetején. 


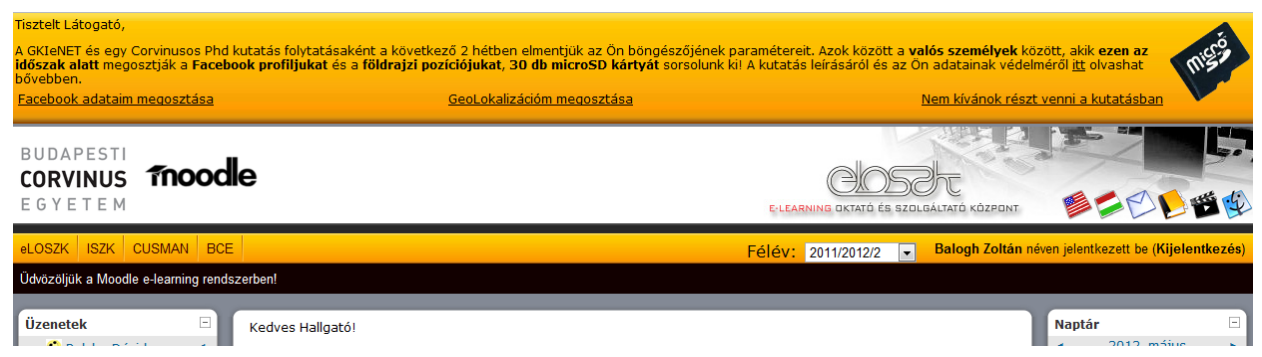

28. ábra: Adatgyújtô alkalmazás megjelenése a Corvinus e-learning rendszerében (saját felvétel)

Az alkalmazás szerveroldali részét egy az Egyetemtől igényelt tárhelyre töltöttem fel, amely az alábbi jellemzókkel rendelkezett:

- 100 MB web tárhely, PHP 5 futtatási lehetőséggel

- 5 GB MySQL tárhely

Mivel az Egyetemtől kapott tárhely PHP szerveroldali alkalmazások futtatására alkalmas, ezért az adatgyújtő alkalmazás szerveroldali részét ezen a programnyelven kellett megírnom. A kliensoldali részét HTML és Javascript nyelven írtam meg. Célom az volt, hogy az alkalmazás a böngészők legszélesebb körén futtatható legyen ${ }^{34}$, amihez nagy segítséget nyújtott a Modeznizr Javascript library. A Modernizr detektálja a böngésző képességeit és egységes formában teszi elérhetővé a programozó számára.

\subsubsection{Az alkalmazás múködése}

Az e-learning rendszerbe történő belépést követően minden egyes oldal tetején megjelent az adatgyújtő alkalmazás, melynek a múködése a 28. ábra: Adatgyújtő alkalmazás megjelenése a Corvinus e-learning rendszerében címú tekinthető meg és az alábbiak szerint múködik:

- Az oldal betöltődését követően az alkalmazás detektálta a böngésző képességeit, a beépített kiegészítők jelenlétét és verziószámát és a telepített betûkészletek listáját, majd elküldte a szerveroldal számára, ahol ez egy rekordként az adatbázisban került eltárolásra.

○ Amennyiben a látogató még nem járt korábban a meglátogatott weboldalon, akkor az alkalmazás szerveroldali része legenerált

\footnotetext{
${ }^{34}$ És a legnépszerúbb 3 böngészőben hibátlanul fusson (Google Chrome, Internet Explorer 6+, Mozilla Firefox 10+)
} 
számára egy egyedi azonosító kódot, amelyet visszaküldött a kliens számára. Ez az egyedi azonosító a kliens oldalon sütibe és localStorageban került eltárolásra későbbi azonosítás céljából.

- Ha azonban a látogató korábban már járt a weboldalon, akkor a sütiből vagy a localStorage-ből visszatöltött az azonosításra alkalmas kódot a detektált adatokkal együtt visszaküldte a szerver számára, így azokat eszközböngészőhöz lehet kapcsolni.

- A földrajzi pozíció megosztása gombra történő kattintás esetén a kliens böngészője a 9. ábra, a Chrome engedélyt kér a látogató földrajzi pozíciójához látható módon rákérdez, hogy valóban szeretné-e megosztani a földrajzi koordinátáit a weboldallal. Amennyiben a felhasználó az igen gombra kattint, a kliens azt a háttérben elküldi a szerver számára a földrajzi koordinátáit egy lekérdezésben.

- A Facebook-on található adataim megosztása gombra történő kattintást követően egy felugró ablakban a Facebook oldalán engedélyezni kell a Facebook számára, hogy az alkalmazás hozzáférhessen a látogató adataihoz. Amennyiben a látogató megerősíti ezt, az alkalmazás egy párhuzamos szálon lementi a látogató Facebook-on található személyes adatait a látogató egyedi azonosítójával együtt

- Abban az esetben, ha a látogató már egyszer engedélyezte az alkalmazás számára, hogy az aktuálisan használt eszközböngészőből a Facebook-on tárolt személyes adatait lementse, akkor többet nem jelenik meg az oldal tetején a 28. ábra: Adatgyújtó alkalmazás megjelenése a Corvinus e-learning rendszerében látható kérdés 


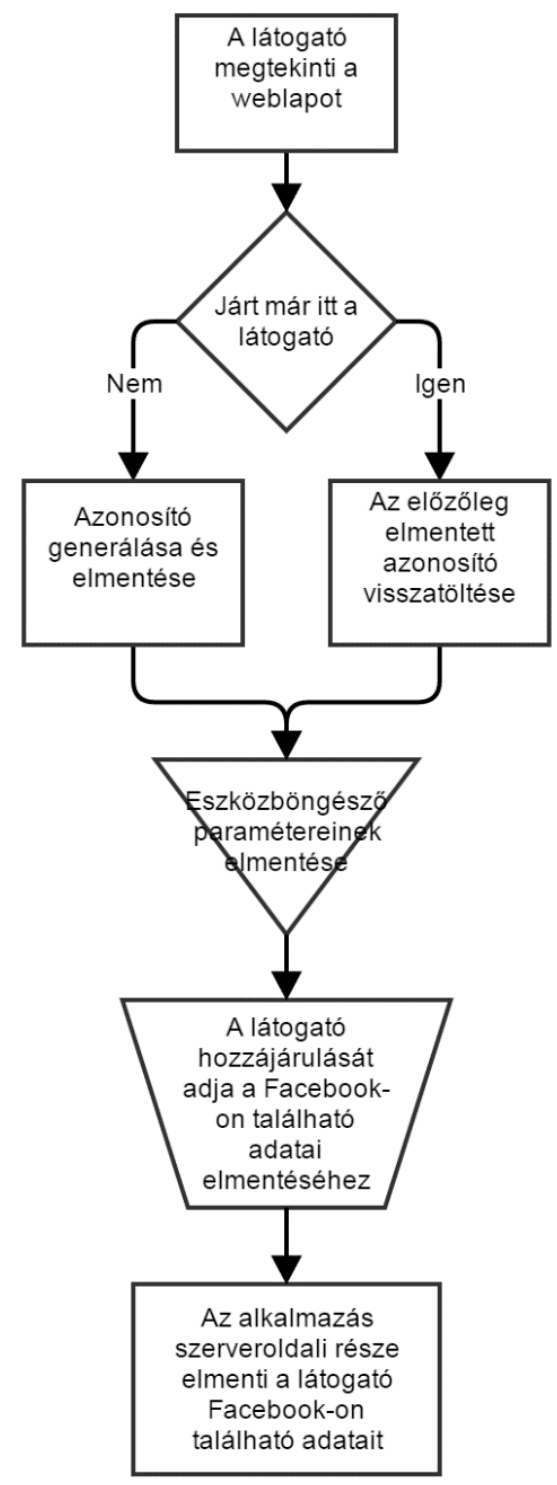

29. ábra: Adatgyújtő alkalmazás vázlatos múködése (saját szerkesztés)

Amíg a kliensnél a sütiben vagy a localStorage-ban eltárolt egyedi azonosító hozzáférhető, a későbbi oldalletöltés adatait is hozzá lehet kötni a korábbi munkamenetekhez. Szándékosan tároltam el két különböző helyen a látogató azonosítóját, mert, ha az egyik azonosítót a felhasználó szándékosan kitörli, az a másikból visszaállítható.

\subsubsection{Hozzáférhetö adatok relevanciája és terhelése}

Az adatgyújtő alkalmazás tervezésénél kiemelt szempont volt, hogy a felhasználói élményt az alkalmazás nem rontsa. (pl: ne kelljen a látogatónak várnia, amíg az alkalmazás a háttérben a Facebook-on tárolt adatait elmenti) Az alábbi táblázatokban összefoglaltam a kliens és a szerver oldalon hozzáférhetô adatok relevanciáját és kinyeréséhez szükséges hardver erőforrás igényét. 


\section{Kliens oldal}

A táblázatban a kliensoldalon hozzáférhető paramétereket gyűjtöttem össze, amelyek Javascript segítségével érhetőek el.

\begin{tabular}{|c|c|c|c|}
\hline Tényező neve & Hozzáférés módja & $\begin{array}{l}\text { Hardver } \\
\text { terhelése }\end{array}$ & Relevancia \\
\hline IP cím & $\begin{array}{l}\text { Nem hozzáférhetô a } \\
\text { kliensoldalon }\end{array}$ & - & - \\
\hline $\begin{array}{l}\text { képernyő } \\
\text { szélessége, } \\
\text { magassága és a } \\
\text { megjelenítés } \\
\text { bitmélysége }\end{array}$ & $\begin{array}{l}\text { Javascript segítségével } \\
\text { lekérdezhető }\end{array}$ & alacsony & magas \\
\hline $\begin{array}{l}\text { eszköz típusa és } \\
\text { verziószáma }\end{array}$ & $\begin{array}{l}\text { A szerveroldalon a lekérdezés } \\
\text { fejlécében a User-Agent String- } \\
\text { ből is kinyerhető }\end{array}$ & közepes & magas \\
\hline $\begin{array}{l}\text { csatlakozáshoz } \\
\text { használt hálózat } \\
\text { típusa }\end{array}$ & $\begin{array}{l}\text { általában mobil eszközök } \\
\text { esetében a kliensoldalon } \\
\text { rendelkezésre álló érték }\end{array}$ & alacsony & közepes \\
\hline HTTP fejléc & $\begin{array}{l}\text { szerveroldalon környezeti } \\
\text { változóként rendelkezésre áll }\end{array}$ & alacsony & magas \\
\hline $\begin{array}{l}\text { CSS3 képességek } \\
\text { HTML5 } \\
\text { képességek }\end{array}$ & $\begin{array}{l}\text { Modernizr library segítségével } \\
\text { detektálható a kliensoldalon }\end{array}$ & közepes & közepes \\
\hline $\begin{array}{l}\text { beépüló modulok } \\
\text { jelenléte és } \\
\text { verziószámának } \\
\text { detektálása }\end{array}$ & $\begin{array}{l}\text { PluginDetect }{ }^{35} \text { library } \\
\text { segítségével a kliensoldalon } \\
\text { hozzáférhető }\end{array}$ & közepes & magas \\
\hline geoLocation & $\begin{array}{l}\text { felhasználói hozzájárulással a } \\
\text { kliensoldalon hozzáférhető }\end{array}$ & alacsony & magas \\
\hline $\begin{array}{l}\text { felhasználó } \\
\text { böngészési } \\
\text { előzménye }\end{array}$ & $\begin{array}{l}\text { előzóleg meglátogatott és a } \\
\text { nyomkövető script által } \\
\text { adatbázisba lementett }\end{array}$ & közepes & közepes \\
\hline
\end{tabular}

\footnotetext{
${ }^{35} \mathrm{http}: / /$ www.pinlady.net/PluginDetect/All/
} 


\begin{tabular}{|c|c|c|c|}
\hline & $\begin{array}{l}\text { előzmények a szerveroldalon } \\
\text { lekérdezhetőek }\end{array}$ & & \\
\hline $\begin{array}{l}\text { egérmozgás } \\
\text { követése }\end{array}$ & \multirow{2}{*}{ a kliensoldalon detektálható } & magas & közepes \\
\hline $\begin{array}{l}\text { billentyú leütések } \\
\text { követése }\end{array}$ & & magas & közepes \\
\hline oldalletöltés ideje & $\begin{array}{l}\text { kliens és szerveroldalon egyaránt } \\
\text { detektálható }\end{array}$ & alacsony & magas \\
\hline meglátogatott URL & $\begin{array}{l}\text { a kliens és szerveroldalon } \\
\text { egyaránt környezeti változóként } \\
\text { elérhető }\end{array}$ & alacsony & magas \\
\hline $\begin{array}{l}\text { generált } \\
\text { eszközböngésző } \\
\text { azonosító }\end{array}$ & $\begin{array}{l}\text { a szerver által generált azonosító, } \\
\text { amelyet vissza kell juttatni a } \\
\text { kliens számára, majd ott } \\
\text { elmenteni sütibe és localStorage- } \\
\text { ba }\end{array}$ & közepes & magas \\
\hline $\begin{array}{l}\text { közösségi } \\
\text { hálózatok által } \\
\text { hozzáférhető } \\
\text { adatok }\end{array}$ & $\begin{array}{l}\text { felhasználó hozzájárulása } \\
\text { szükséges, harmadik féltől } \\
\text { hozzáférhető adat }\end{array}$ & magas & magas \\
\hline $\begin{array}{l}\text { telepített } \\
\text { betútípusok listája }\end{array}$ & $\begin{array}{l}\text { Flash plugin szükséges a lista } \\
\text { letöltéséhez, majd Javascript } \\
\text { segítségével kinyerni a Flash } \\
\text { plugin-ből }\end{array}$ & közepes & magas \\
\hline inkognitó mód & $\begin{array}{l}\text { régebben volt lehetséges az } \\
\text { inkognitó mód detektálására, a } \\
\text { korszerű böngészőkben ez már } \\
\text { nem lehetséges }\end{array}$ & közepes & alacsony \\
\hline
\end{tabular}

A táblázatban a detektálható paraméterek és a magyarázatuk mellett feltüntettem azok hardver terhelését és relevanciáját. A hardver terhelés oszlopban feltüntetett értékek az adott paraméter kinyeréséhez szükséges kliens oldali erőforrás szintjét jelzik. Az alacsony hardverigény egy környezeti változó kiolvasását jelenti, a közepes hardverigény a kliensoldalba betöltött middleware-től kapott értéket jelenthet, 
a magas hardverigény pedig harmadik féltől származó adatok áttöltését vagy a billentyűleütések/egérmozgás folyamatos detektálását és elküldését jelenti.

Az alkalmazás tervezésénél az alacsony és közepes hardverigényú paraméterek mindegyikét elmentettem, a magas hardverigényúek közül a közösségi hálózatokról elérhető személyes adatokat a szerveroldalon töltöm át, így az nem befolyásolja negatívan a látogató élményét. $\mathrm{Az}$ egérmozgás és billentyưzet használat detektálásának lehetőségét teljesítményi okokból a végső alkalmazásból kivettem.

\section{Szerver oldal}

Mivel a szerveroldal kevésbé befolyásolja a kliensoldali felhasználói élményt az elmentendő adatok terhelését és relevanciáját a szerveroldali hardverigény és programozási technológia helyes megválasztása miatt tettem.

\begin{tabular}{|c|c|c|c|}
\hline Tényezó neve & Hozzáférés módja & $\begin{array}{l}\text { Hardver } \\
\text { terhelése }\end{array}$ & Relevancia \\
\hline IP cím & $\begin{array}{l}\text { környezeti változóként áll } \\
\text { rendelkezésre, amennyiben a } \\
\text { látogató proxy mögött van, } \\
\text { nem a valós IP címét adja } \\
\text { vissza }\end{array}$ & alacsony & magas \\
\hline HTTP fejléc & $\begin{array}{l}\text { szerveroldalon környezeti } \\
\text { változóként rendelkezésre áll }\end{array}$ & alacsony & magas \\
\hline $\begin{array}{l}\text { operációs rendszer } \\
\text { típusa és } \\
\text { verziószáma }\end{array}$ & $\begin{array}{l}\text { a HTTP fejléc User-Agent } \\
\text { string-jéből API-n keresztül } \\
\text { vagy egy ingyenesen }\end{array}$ & közepes & magas \\
\hline $\begin{array}{l}\text { böngésző típusa és } \\
\text { verziószáma }\end{array}$ & $\begin{array}{l}\text { hozzáférhetô adatbázis }{ }^{36} \\
\text { segítségével határozható meg }\end{array}$ & közepes & magas \\
\hline host & $\begin{array}{l}\text { általában beépített parancs } \\
\text { segítségével oldalható fel }\end{array}$ & közepes & magas \\
\hline ISP & $\begin{array}{l}\text { harmadik fél adatbázisából } \\
\text { lekérdezhető (nem szükséges a } \\
\text { lekérdezés időpontjában } \\
\text { elvégezni) }\end{array}$ & magas & magas \\
\hline
\end{tabular}

\footnotetext{
${ }^{36}$ PHP UserAgent Master
} 


\begin{tabular}{|c|c|c|c|}
\hline $\begin{array}{l}\text { csatlakozáshoz } \\
\text { használt hálózat } \\
\text { típusa }\end{array}$ & $\begin{array}{l}\text { A szerveroldalon nem áll } \\
\text { rendelkezésre }\end{array}$ & - & - \\
\hline $\begin{array}{l}\text { felhasználó } \\
\text { böngészési } \\
\text { előzménye }\end{array}$ & $\begin{array}{l}\text { a kliensoldalon nem } \\
\text { hozzáférhető, az előzőleg } \\
\text { meglátogatott és a nyomkövető } \\
\text { script által adatbázisba } \\
\text { lementett előzmények a } \\
\text { szerveroldalon lekérdezhetőek } \\
\text { (nem szükséges a lekérdezés } \\
\text { időpontjában elvégezni) }\end{array}$ & közepes & közepes \\
\hline $\begin{array}{l}\text { meglátogatott } \\
\text { webhely } \\
\text { bejárásának } \\
\text { módja }\end{array}$ & $\begin{array}{l}\text { a látogató böngészési } \\
\text { előzményeiből kinyerhető adat } \\
\text { (nem szükséges a lekérdezés } \\
\text { időpontjában elvégezni) }\end{array}$ & magas & közepes \\
\hline oldalletöltés ideje & $\begin{array}{l}\text { kliens és szerveroldalon } \\
\text { egyaránt detektálható }\end{array}$ & alacsony & magas \\
\hline $\begin{array}{l}\text { meglátogatott } \\
\text { URL }\end{array}$ & $\begin{array}{l}\text { a kliens és szerveroldalon } \\
\text { egyaránt környezeti } \\
\text { változóként elérhető }\end{array}$ & alacsony & magas \\
\hline $\begin{array}{l}\text { generált } \\
\text { eszközböngésző } \\
\text { azonosító }\end{array}$ & $\begin{array}{l}\text { a szerver által generált } \\
\text { azonosító, amelyet vissza kell } \\
\text { juttatni a kliens számára, majd } \\
\text { ott elmenteni sütibe és } \\
\text { localStorage-ba }\end{array}$ & közepes & magas \\
\hline $\begin{array}{l}\text { közösségi } \\
\text { hálózatok által } \\
\text { hozzáférhető } \\
\text { adatok }\end{array}$ & $\begin{array}{l}\text { felhasználó hozzájárulása } \\
\text { szükséges, harmadik féltől, } \\
\text { célszerü a szerveroldalon } \\
\text { letölteni, mivel a sok adat } \\
\text { letöltése a kliens által ronthatja } \\
\text { a böngészési élményt, } \\
\text { valamint, a felhasználó } \\
\text { megszakíthatja a múveletet, }\end{array}$ & magas & magas \\
\hline
\end{tabular}




\begin{tabular}{|l|l|c|c|}
\hline & $\begin{array}{l}\text { így értékes információkat } \\
\text { veszíthet el a nyomkövető } \\
\text { alkalmazás }\end{array}$ & \\
\hline $\begin{array}{l}\text { harmadik féltőll } \\
\text { hozzáférhetó adat }\end{array}$ & $\begin{array}{l}\text { szerveroldalon letölthető } \\
\text { harmadik féltől }\end{array}$ & $\begin{array}{r}\text { közepes - } \\
\text { magas }\end{array}$ & $\begin{array}{c}\text { közepes - } \\
\text { magas }\end{array}$ \\
\hline
\end{tabular}

A közösségi hálózatok által hozzáférhető adatok hardverterhelése igen magas, hiszen a lekérdezés több 10 másodpercig is eltarthat az áttöltendő adatok mennyiségének függvényében, emiatt ezt a részfeladatot egy külön szálon futtattam a lekérdezés blokkolása nélkül.

\subsubsection{A lementett adatok listája}

Az adatgyújtő alkalmazás által lementett adatok teljes listája és az egyes értékek magyarázata az alábbi táblázatban olvasható.

\begin{tabular}{ll}
\hline MySQL adatbázis mezó neve & A mezóben tárolt érték \\
\hline userId & az eszközböngészó számára kiosztott azonosító \\
facebookId & a látogató Facebook azonosítója \\
facebookFirstName & Facebook-on használt név \\
\hline facebookLastName & Facebook-on használt keresztnév \\
\hline facebookGender & Facebook-on használt vezetéknév \\
\hline facebookUsername & Facebook-on megadott nem \\
\hline facebookBirthday & Facebook-on megadott felhasználónév \\
facebookHometown & Facebook-on megadott születésnap \\
\hline facebookLocation & Facebook-on megadott születési hely \\
facebookFriends & Facebook-on megadott jelenlegi helyzet \\
facebookComments & Facebook-on lévó barátok listája \\
facebookLikes & a látogató Facebook kommentjei \\
facebookFeed & a látogató Facebook like-jai \\
\hline datetime & a látogató Facebook fala \\
\hline IP & a record elmentésének dátuma \\
\hline screenWidth & az internetezéshez használt eszközböngésző IP \\
\hline & címe \\
\hline
\end{tabular}




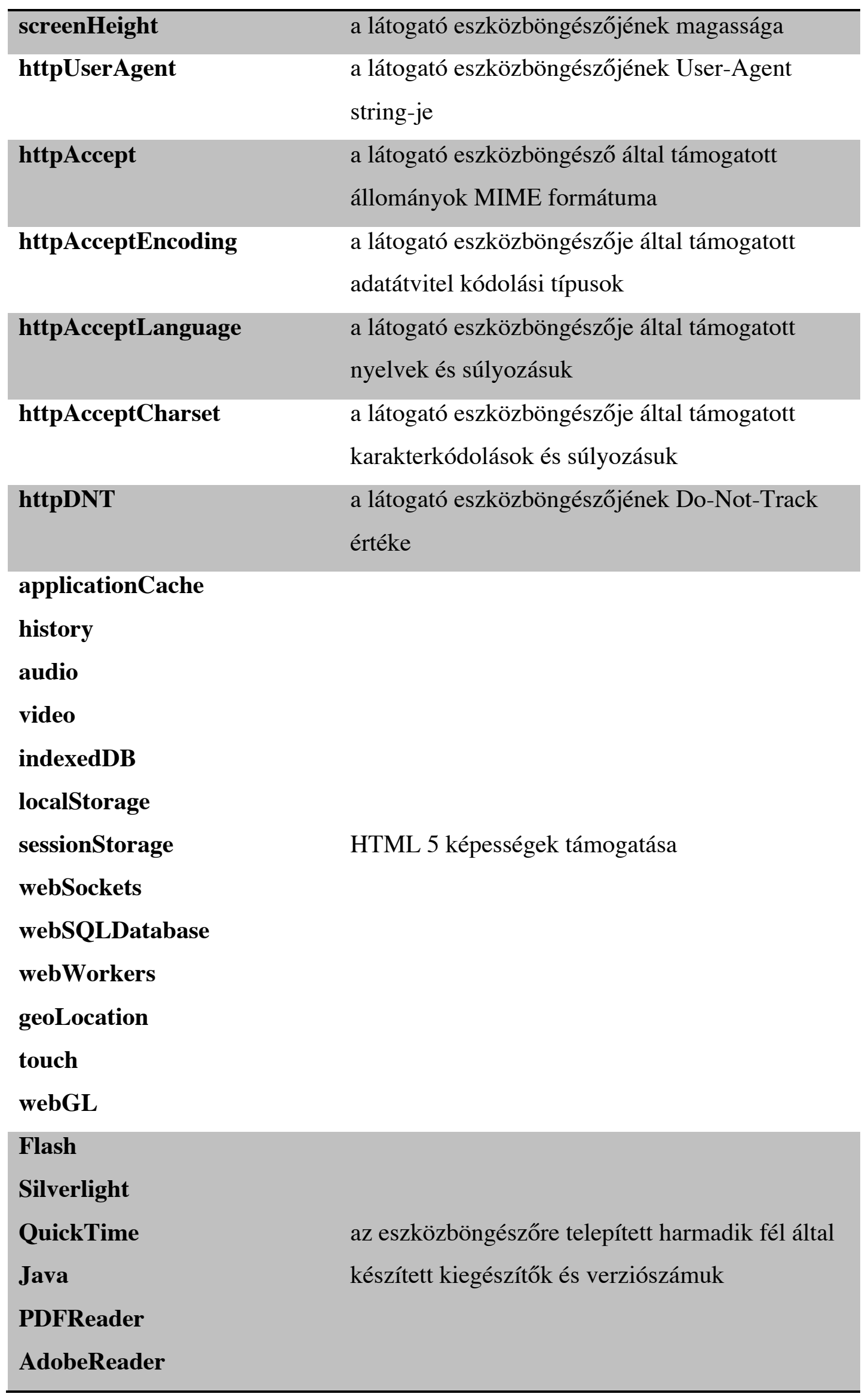




\begin{tabular}{|c|c|}
\hline referrer & $\begin{array}{l}\text { a látogató által megtekintett e-learning oldal } \\
\text { URL-je }\end{array}$ \\
\hline connection Type & $\begin{array}{l}\text { a csatlakozáshoz használt kapcsolat típusa, csak } \\
\text { mobil eszközök esetében használt }\end{array}$ \\
\hline isFlashBlocked & $\begin{array}{l}\text { a látogató eszközböngészőjére Flash blokkoló } \\
\text { telepítve van }\end{array}$ \\
\hline isGeo & $\begin{array}{l}\text { ha az értéke } 1 \text {, akkor a postitionLatitude és a } \\
\text { positionLongitude mezók értéke a GeoLocation } \\
\text { API-ból érkezett } \\
\text { ha az értéke } 0 \text {, akkor a postitionLatitude és a } \\
\text { positionLongitude mezők értéke IP címből } \\
\text { visszafejtett hozzávetôleges pozíció }\end{array}$ \\
\hline positionLatitude & $\begin{array}{l}\text { a látogató eszközböngészőjének földrajzi } \\
\text { pozíciójának szélességi foka }\end{array}$ \\
\hline positionLongitude & $\begin{array}{l}\text { a látogató eszközböngészőjének földrajzi } \\
\text { pozíciójának hosszúsági foka }\end{array}$ \\
\hline fonts & $\begin{array}{l}\text { a böngészéshez használt eszközre telepített } \\
\text { betútípusok listája }\end{array}$ \\
\hline fontsCounter & $\begin{array}{l}\text { a böngészéshez használt eszközre telepített } \\
\text { betûtípusok száma }\end{array}$ \\
\hline browserFamily & a böngészéshez használt böngésző típusa \\
\hline osFamily & $\begin{array}{l}\text { a böngészéshez használt eszközböngésző } \\
\text { operációs rendszere }\end{array}$ \\
\hline osVersion & $\begin{array}{l}\text { a böngészéshez használt eszközböngésző } \\
\text { operációs rendszerének verziója }\end{array}$ \\
\hline device & a böngészéshez használt eszköz \\
\hline
\end{tabular}




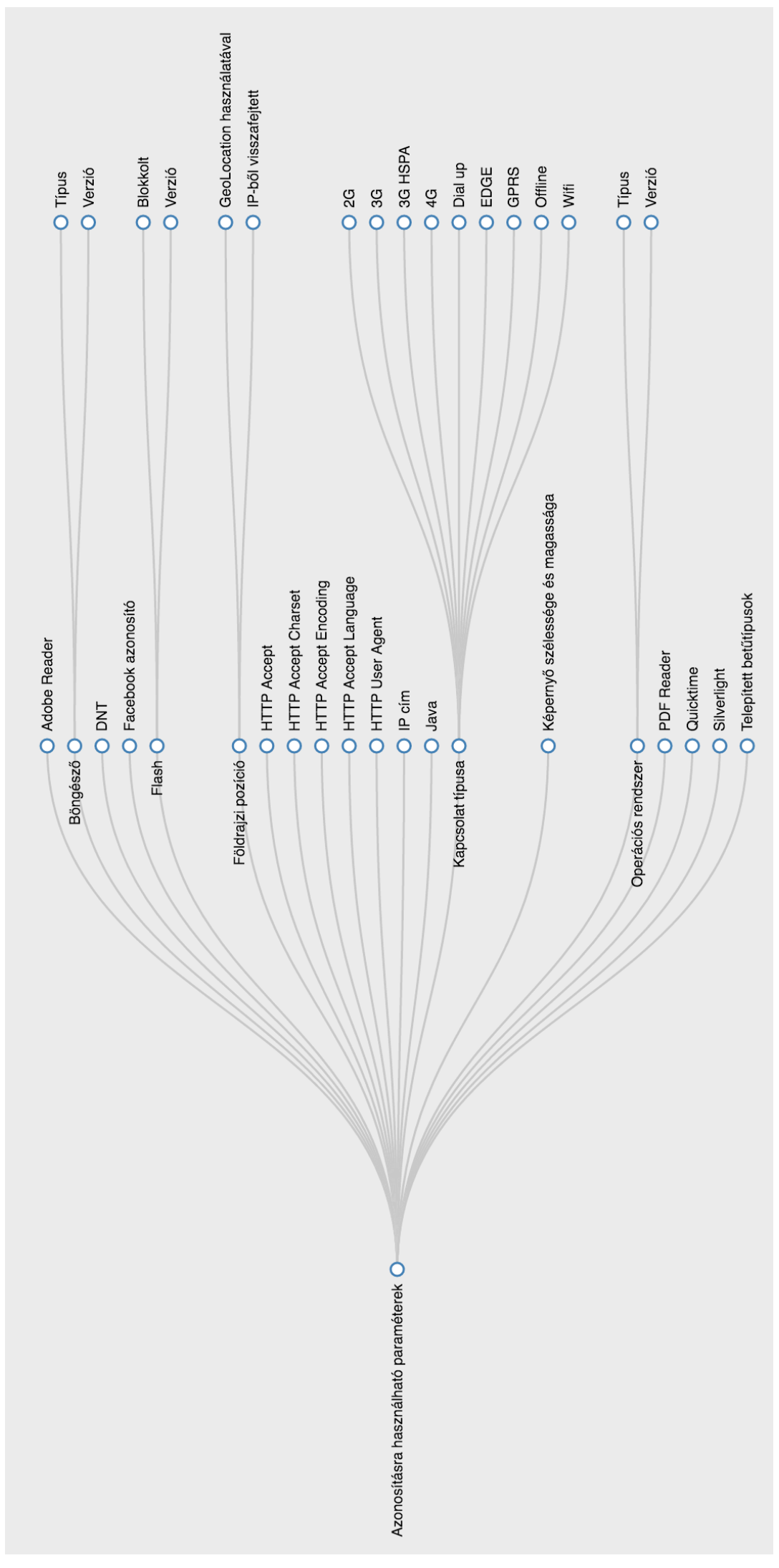

30. ábra: Azonositásra használható eszközböngészóból kinyerhető paraméter és felvehetó értékei (saját szerkesztés) 


\subsubsection{A lementett adatok statisztikai jellemzöi}

Az adatgyűjtési időszak leteltét követôen kerülhetett sor az adatbázisba elmentett paraméterek statisztikai vizsgálatára. Az alábbi táblázatban összefoglaltam a lementett paraméterek néhány alapvető statisztikáját: a mintában található kitöltött értékek száma és aránya, a különböző értékek számossága és aránya, valamint a különböző értékek eszközböngészőkhöz viszonyított aránya.

\begin{tabular}{|c|c|c|c|}
\hline Paraméter neve & Kitöltött érték & $\begin{array}{c}\text { Különböző } \\
\text { értékek }\end{array}$ & $\begin{array}{c}\text { Különböző } \\
\text { értékek a } \\
\text { kiosztott } \\
\text { eszközböngészők } \\
\text { arányában }\end{array}$ \\
\hline $\begin{array}{l}\text { Kiosztott egyedi } \\
\text { azonosító (userID) }\end{array}$ & 647242 (100\%) & $32529(5,02 \%)$ & - \\
\hline $\begin{array}{l}\text { Facebook azonosító } \\
\text { (userID) }\end{array}$ & $176(0,02 \%)$ & $139(0,02 \%)$ & $0,42 \%$ \\
\hline IP cím & $647242(100 \%)$ & $31781(4,91 \%)$ & $97,70 \%$ \\
\hline $\begin{array}{l}\text { Képernyő magassága és } \\
\text { szélessége }\end{array}$ & $647242(100 \%)$ & $1490(0,23 \%)$ & $4,58 \%$ \\
\hline HTTP user agent & $647242(100 \%)$ & $2173(0,3 \%)$ & $6,68 \%$ \\
\hline HTTP accept & $647242(100 \%)$ & $9(0,00 \%)$ & $0,02 \%$ \\
\hline HTTP accept encoding & $647242(100 \%)$ & $13(0,00 \%)$ & $0,03 \%$ \\
\hline HTTP accept language & $647242(100 \%)$ & $9(0,00 \%)$ & $0,02 \%$ \\
\hline HTTP accept charset & $647242(100 \%)$ & $22(0,00 \%)$ & $0,07 \%$ \\
\hline DNT & $647242(100 \%)$ & $2(0,00 \%)$ & $0,01 \%$ \\
\hline Böngésző típusa & $647242(100 \%)$ & $7(0,00 \%)$ & $0,02 \%$ \\
\hline $\begin{array}{l}\text { Böngésző típusa és } \\
\text { verziószáma }\end{array}$ & 647242 (100\%) & $206(0,03 \%)$ & $0,63 \%$ \\
\hline $\begin{array}{l}\text { Operációs rendszer } \\
\text { típusa }\end{array}$ & $647242(100 \%)$ & $8(0,00 \%)$ & $0,02 \%$ \\
\hline $\begin{array}{l}\text { HTML } 5 \text { képességek } \\
\text { (application cache, }\end{array}$ & $647242(100 \%)$ & $2(0,00 \%)$ & $0,01 \%$ \\
\hline
\end{tabular}




\begin{tabular}{|c|c|c|c|}
\hline $\begin{array}{l}\text { history, audio, video, } \\
\text { indexedDB, localStorage, } \\
\text { sessionStorage, } \\
\text { webSocket, webSQL, } \\
\text { web workers, } \\
\text { geoLocation, } \\
\text { érintőképernyő, webGL) }\end{array}$ & & & \\
\hline Flash verziója & $\begin{array}{r}624459 \\
(96,47 \%)\end{array}$ & $104(0,02 \%)$ & $0,32 \%$ \\
\hline Silverlight verziója & $\begin{array}{r}502649 \\
(77,66 \%)\end{array}$ & $25(0,00 \%)$ & $0,08 \%$ \\
\hline Quicktime verziója & $\begin{array}{r}250959 \\
(38,77 \%)\end{array}$ & $38(0,01 \%)$ & $0,12 \%$ \\
\hline Java verziója & $\begin{array}{r}348693 \\
(53,87 \%)\end{array}$ & $50(0,01 \%)$ & $0,15 \%$ \\
\hline PDF Reader verziója & $\begin{array}{r}534152 \\
(82,52 \%)\end{array}$ & $1(0,00 \%)$ & $0,01 \%$ \\
\hline Adobe Reader verziója & $\begin{array}{r}334969 \\
(51,75 \%)\end{array}$ & $89(0,01 \%)$ & $0,27 \%$ \\
\hline URL (referrer) & $647242(100 \%)$ & $17353(2,68 \%)$ & $53,35 \%$ \\
\hline Kapcsolat típusa & $647242(100 \%)$ & $4(0,00 \%)$ & $0,01 \%$ \\
\hline $\begin{array}{l}\text { Flash blokkoló } \\
\text { használata }\end{array}$ & $647242(100 \%)$ & $2(0,00 \%)$ & $0,01 \%$ \\
\hline $\begin{array}{l}\text { Szélességi és hosszúsági } \\
\text { fok }\end{array}$ & $647242(100 \%)$ & $2(0,00 \%)$ & $0,01 \%$ \\
\hline Telepített betútípusok & $\begin{array}{r}619301 \\
(95,68 \%)\end{array}$ & $14895(2,30 \%)$ & $45,78 \%$ \\
\hline
\end{tabular}

33. táblázat: a lementett paraméterek statisztikai jellemzói

A táblázat utolsó oszlopában vastagon szedett betúkkel jelöltem azon paramétereket, amelyek esetében magas a különböző értékek aránya a mintában. (IP cím, HTTP user agent, URL (referrer) és telepített betútípusok) A kiemelt értékek 
közül az IP cím biztosan nem használható az eszközböngészők azonosítására, hiszen dinamikus IP-t használó eszközök esetében ez az érték gyakran változhat. A URL szintén a megtekintett tartalom függvényében változik, így marad a HTTP UserAgent, ami a böngésző és az operációs rendszer nevét és verziószámát tömöríti, valamint az eszközböngészőre telepített betûtípusok listája, amely böngészőfüggetlen, így akkor is alkalmas az eszköz azonosítására, ha a látogató böngészőt vált.

\subsubsection{A feldolgozott adatok listája}

Az adatok lementését követóen következett az adatok előfeldolgozása és nominálissá való alakítása, mivel az Apriori algoritmus csak ilyen típusú inputváltozókat fogad el. Az alábbi listában foglaltam össze az adatbázisból az Apriori algoritmus input adatait és azok értelmezését:

- is_DNT_on: a látogató böngészőjének Do-Not-Track beállításának állapota

- has_flash: van-e Flash plugin telepítve a látogató böngészőjére

- is_flash_blocked: amennyiben van Flash plugin telepítve, az blokkolva van-e

- has_silverlight: van-e Silverlight plugin telepítve

- has_quicktime: van-e Quicktime plugin telepítve

- has_java: van-e Java plugin telepítve

- has_PDFReader: a látogató böngészőjének van-e PDF olvasási képessége

- has_AdobeReader: van-e Adobe Reader plugin telepítve a látogató böngészőjére

- connection_type: a mező értékei a HTML 5 Network Information API-jának értékei
○ 0 - Ismeretlen
○ 1 - Ethernet kapcsolat
○ $2-\mathrm{WiFi}$
○ 3 - Mobiltelefonos 2G kapcsolat
○ 4 - Mobiltelefonos 3G kapcsolat
○ 5 - Mobiltelefonos 4G kapcsolat
○ 6 - Mobiltelefonos kapcsolat
○ 7 - Nincs kapcsolat

- browserFamily: a látogató böngészőjének típusa

- osFamily: a böngészéshez használt operációs rendszer típusa 
- device: a böngészéshez használt eszköz típusa

- mobile_os_family: mobil operációs rendszer esetében annak neve

- font_counter: a látogató operációs rendszerére telepített betútípusok száma

- screen_size: a képernyő felbontása (a képernyő szélessége alapján)

○ ha a képernyő szélessége $<=600$, akkor svga

○ ha a képernyő szélessége $>600$, de $<=1024$, akkor xga

○ ha a képernyő szélessége $>1024$, de $<=1280$, akkor sxga

○ ha a képernyő szélessége $>1280$, de $<=1400$, akkor sxga_plus

○ ha a képernyő szélessége $>1400$, de $<=1920$, akkor hd

○ ha a képernyő szélessége > 1920, akkor 4k

- number_of_pageloads: a látogatóhoz tartozó oldalletöltések száma

- cardinality_of_sessions: a látogató által megkezdett munkamenetek száma

- geo_category: a böngészés helyszíne

○ 1: Európán kívül

○ 2: Európán belül

○ 4: Magyarország, Budapest

○ 5: Magyarország, megyeszékhely

○ 6: Magyarország, egyéb település

- cardinality_of_locations: különböző helyszínek számossága

- activity_dawn: 4:00-7:00 közötti oldalletöltések száma

- activity_forenoon: 7:00-10:00 közötti oldalletöltések száma

- activity_noon: 10:00-14:00 közötti oldalletöltések száma

- activity_afternoon: 14:00-18:00 közötti oldalletöltések száma

- activity_evening: 18:00-23:00 közötti oldalletöltések száma

- activity_night: 23:00-4:00 közötti oldalletöltések száma

\section{Osztályváltozóként használt változók}

Az alábbiakban az osztályváltozóként használt személyhez köthető változókat sorolom fel:

- course: a látogató által látogatott kurzus

- department: a látogató által látogatott kurzus tanszéke

- cardinality_of_likes: Facebook Like-ok számossága

- nem: 0 - férfi, 1 - nő 
A myPersonality API által visszaadott 0 és 1 közötti értékek a vizsgált mintára vonatkozó percentilis értékek. [10]

- satisfaction_life: élettel való megelégedettség

- intelligence: intelligencia, amely az alábbi képlettel határozható meg:

$$
\mathrm{IQ}=77,941+44,118 \times \text { intelligencia }
$$

- s_yes: kapcsolatban

- r_christian: keresztény vallású

- b_agreeableness: Big5 barátságosság értéke

- b_conscientiousness: Big5 lelkiismeretesség értéke

- b_openness: Big5 nyitottság értéke

- b_neuroticism: Big5 neurotikusság értéke

- b_extraversion: Big5 extrovertáltság értéke

- p_uninvolved: nem érdekli a politika

- p_conservative: politikailag konzervatív 


\subsection{Idézett források}

\subsubsection{Tudományos szakirodalmi müvek}

Abramson, M., \& Aha, D. W. (2013). User authentication from Web browsing behavior. Florida Artificial Intelligence Research Society Conference (old.: 6). St. Pete Beach: AAAI Press.

Agrawal, R., \& Srikant, R. (1994). Fast Algorithms for Mining Association Rules. $V L D B$ '94 Proceedings of the 20th International Conference on Very Large Data Bases (old.: 487-499). San Francisco: Morgan Kaufmann Publishers Inc. András, N., \& Péter, S. (2015). Empirical Analysis of Information Security Awareness in the Business and Public Sectors of Hungary. Central and Eastern European elDem and elGov (old.: 405-418). Wien: Leibniz Information Centre for Economics.

Andreas, P., \& Marit, H. (2010. augusztus 10). Privacy and Data Security, TU Dresden, Faculty of Computer Science. Forrás: A terminology for talking about privacy by data minimization: Anonymity, Unlinkability, Undetectability, Unobservability, Pseudonymity, and Identity Management: http://dud.inf.tu-dresden.de/Anon_Terminology.shtml

Andrews, G., Gilbert, J., Repper, M., Roth, G., \& Wear, J. (2011). Internet Anonymity. Forrás: Anonymity on the Internet - CS 181 Final Project, Spring 2011: https://sites.google.com/site/cs181anonymity/definition

Barabási, A. (2010). Villanások - a jövó kiszámítható. Budapest: Helikon Kiadó Kft.

Bodon, F. (2010. február 28). Adatbányászati algoritmusok. Budapest, Magyarország. Brett, B. (2011). The Psychology of Sharing: Why do people share online? The New York Times.

Carlos, G.-U. A., \& Neil, H. (2015. december). The Netflix Recommender System: Algorithms, Business Value, and Innovation. ACM Transactions on Management Information Systems, 6, 19.

Chris, H. J., Ashkan, S., Nathaniel, G., \& Dietrich, W. J. (2012. january 1). Behavioral Advertising: The Offer You Can't Refuse. Harvard Law \& Policy Review vol. 6, old.: 273-296.

Clarke, R. (1999). Internet Privacy Concerns Confirm the Case for Intervention. Communications of ACM, 60-67. 
Cser, L., \& Fajszi, B. (2004). Üzleti tudás az adatok mélyén - Adatbányászat alkalmazói szemmel. Budapest: Budapesti Múszaki és Gazdálkodástudományi Egyetem.

Cser, L., Nagyné Polyák, I., \& Németh, Z. (2007). Informatikai Alapok. Debrecen: Debreceni Egyetem Agrár- és Műszaki Tudományok Centruma.

Danezis, G., Domingo-Ferrer, J., Hansen, M., Hoepman, J.-H., Le Métayer, D., Tirtea, R., \& Schiffner, S. (2015. január 12). European Union Agency for Network and Information Security. Letöltés dátuma: 2017. május 14, forrás: Privacy and Data Protection by Design: https://www.enisa.europa.eu/publications/privacyand-data-protection-by-design

Davenport, D. (2002. április). Anonymity on the Internet: Why the Price May Be Too High. Communications of the ACM vol. 45, no. 4, old.: 33-35.

Domokos, M. N. (2013). Az EU új adatvédelmi szabályozása - avagy „keep bangin' on the wall of Fortress Europe". Jogi Fórum, 1-46.

Eckersley, P. (2013, january 26). Electronic Frontier Foundation - Defending your rights in the digital world. Retrieved april 19, 2013, from A Primer on Information Theory and Privacy: https://www.eff.org/deeplinks/2010/01/primer-information-theory-andprivacy

ENISA. (2017). European Union Agency for Network and Information Security. Letöltés dátuma: 2017. május 14, forrás: About ENISA: https://www.enisa.europa.eu/about-enisa

Escobido, M., \& Gillian, S. (2013). Can Personality Type be Predicted by Social Media Network Structures? The Asian Conference on Psychology \& the Behavioral Sciences. Osaka: The International Academic Forum.

Európai Bizottság. (2015. július 11). A személyes adatok védelme. Forrás: Európai Bizottság honlapja: http://ec.europa.eu/justice/data-protection/index hu.htm

France, B., \& Robert, C. E. (2011). Privacy in the digital age: A review of information privacy research in information systems. MISQ, volume 35, issue 4, 1017-1041.

Golbeck, J., Robles, C., \& Turner, K. (2011). Predicting personality with social media. CHI'11 Extended Abstracts on Human Factors in Computing Systems (old.: 253-262). New York: ACM New York.

Haig, Z., Kovács, L., Ványa, L., \& Vass, S. (2014). Elektronikai hadviselés. Budapest: Nemzeti Közszolgálati Egyetem. 
Hunyadi, L., \& Vita, L. (2006). Statisztika közgazdászoknak. Budapest: Központi Statisztikai Hivatal.

Iváncsy, R., \& Juhász, S. (2007). Analysis of Web User Identification. International Journal of Computer Science;2007, Vol. 2 Issue 3, 212.

Jeffrey, R. S. (2012). Facebook: A Case Study of Strategic Leadership. Zurich: Swiss Management Center - Transknowlogy Campus.

Jia-Ching, Y., Chu-Yu, C., \& Vincent, T. S. (2012). Mining web navigation patterns with dynamic thresholds for navigation prediction. IEEE Computer Society 2012 (old.: 614-619). Hangzhou: IEEE.

John, L., Manuel, B., \& Luis, A. v. (2004. február). Telling Humans and Computers Apart Automatically. Communications of the ACM, 57-60. Letöltés dátuma: 2013. július 14, forrás: http://www.cs.cmu.edu/ biglou/captcha_cacm.pdf

Jurafsky, D., \& Manning, C. (2012. april 4). Precision, Recall, and the F measure. Stanford NLP.

Kang, R., Brown, S., \& Kiesler, S. (2013). Why do people seek anonymity on the internet?: informing policy and design. Proceedings of the SIGCHI Conference on Human Factors in Computing Systems, 2657-26666.

Kennedy, H. (2006). Beyond anonymity, or future directions for internet identity research. New Media \& Society, Vol 8, Issue 6, 859-876.

Kiss, A. (2015. február 23). Az adatokhoz, adatbázisokhoz kapcsolódó jogi szabályozás 1. (A. Kiss, Előadó) Budapest.

Kosinksi, M., Stillwell, D., \& Graepel, T. (2013). Private traits and attributes are predictable from digital records of human behavior. PNAS, 5802-5805.

Kosinksi, M., Stillwell, D., \& Graepel, T. (2013). Private traits and attributes are predictable from digital records of human behavior. In U. o. Kenneth Wachter (Szerk.), Proceedings of the National Academy of Sciences of the United States of America. 110, old.: 5802-5805. Berkeley: PNAS.

Kosinski, M., Bachrach, Y., Kohli, P., Stillwell, D., \& Graepel, T. (2013. october 19). Manifestations of user personality in website choice and behaviour on online social networks. Machine Learning, June 2014, Volume 95, old.: 357-380.

Kosinski, M., Las Casas, D., Paulo Pesce, J., Quercia, D., Stillwell, D., Almeida, V., \& Crowcroft, J. (2012). Facebook and Privacy: The Balancing Act of Personality, Gender, and Relationship Currency. Sixth International AAAI Conference on Weblogs and Social Media. Dublin: ICWSM. 
Kovács, E. (2014). Többváltozós adatelemzés. Budapest: Typotex.

Kovács, L. (2013). Cyberterrorizmus: valós vagy túldimenzionált veszély? Magyar rendészet XIII. (különszám), old.: 85-93.

Mano, K. (2011. november). Mathematical Duality between Anonymity and Privacy and Its Application to Law. NTT Technical Review Vol.9, No. 11, old.: 1-7.

Marx, G. T. (1999). What's in a Name? Some Reflections on the Sociology of Anonymity. The Information Society, 99-112.

Mirnics, Z. (2006). A személyiség építókövei. Budapest: Bölcsész Konzorcium.

Nan, Z., Aaron, P., \& Haining, W. (dátum nélk.). An Efficient User Verification System via Mouse.

Nemeslaki, A., \& Pocsarovszky, K. (2011. szeptember 18). Web crawler research methodology. Web Crawler Research Methodology, (old.: 1-17). Budapest.

Nemeslaki, A., \& Sasvári, P. (2015). Empirical Analysis of Information Security Awareness in the Business and Public Sectors of Hungary. Central and Eastern European elDem and elGov Days 2015 (old.: 405-418). Bécs: Druckerei Riegelnik.

Nemeslaki, A., Kis, G., Duma, L., \& Szántai, T. (2004). e-Business: Üzleti modellek. Budapest: ADECOM Kommunikációs Szolgáltató Rt.

Peter, O., David, G., David, L., Warren, F., \& Jonathan, N. B. (2005). Continuous Identity Verification. Jur, 20-24.

Poria, S., Gelbukh, A., Agarwal, B., Cambria, E., \& Howard, N. (2013). Common Sense Knowledge Based Personality Recognition from Text. Advances in Soft Computing and Its Applications (old.: 484-496). Mexico City: Springer Berlin Heidelberg.

Racskó, P. (2012). A számítási felhő az Európai Unió Egén. Vezetéstudomány, old.: 116.

Regina, D. E. (2012. november 13). Y és Z generáció mint a jövó munkavállalói. Forrás:

Kormányhivatal: http://www.kormanyhivatal.hu/download/2/18/60000/Y\%20\%C3\%A9s\%20Z \%20gener\%C3\%A1ci\%C3\%B3\%20mint\%20a\%20j\%C3\%B6v\%C5\%91\%20 munkav\%C3\%A11lal\%C3\%B3i.pdf

Rétallér, O., \& Balogh, Z. (2015. december). Specialities of Psychological Traits of Citizens of Corvinus University of Budapest. Hadmérnök, 15. 
Rigby, K. (1995). Anonymity on the Internet Must be Protected. Paper for MIT.

Robyn, R. L., Krishen, A. S., \& Kachroo, P. (2014). Understanding the Components of Information Privacy Threats for Location-Based Services. Journal of Information Systems, 227-242.

Rössler, B. (2004). The Value of Privacy. Amsterdam: John Wiley \& Sons.

Sander, T., Majláth, M., Sloka, B., \& Lee Teh, P. (2015). User preference and channels use in the employment seeking process. Management, Enterprise and Benchmarking in the 21st century II. (old.: 239-248). Budapest: Óbuda University.

Shababi, C., Zarkesh, M. A., Adibi, J., \& Shah, V. (1997). Knowledge discovery from users web page navigation. 26th IEEE International Conference on research in Data Engineering, (old.: 20-29).

Shannon, C. E. (1948). A Mathematical Theory of Communication. The Bell System Technical Journal, 379-423.

Shivani, H. (2004). Authentication by Mouse Movements.

Stillwell, D. J., \& Kosinki, M. (2012). myPersonality project: Example of successful utilization of online social networks for large-scale social research. Cambridge, University of Cambridge, UK: The Psychometrics Centre.

Stillwell, D., Kosinki, M., Rust, J., \& Wang, N. (2012. february 3). Can Well-Being be Measured Using Facebook Status Updates? Validation of Facebook's Gross National Happiness Index. Social Indicators Research vol 115, issue 1, old.: 483-491.

Szabó, A. (2010). Random Forests - Véletlen erdók. Letöltés dátuma: 2017. január 8, forrás: Adatbányászat és Keresés Csoport: https://dms.sztaki.hu/sites/dms.sztaki.hu/files/file/2011/randomforests.pdf

Személyes adatok feldolgozása vonatkozásában az egyének védelméről és az ilyen adatok szabad áramlásáról, 95/46/EK (Az Európai Parlament és a Tanács 1995. október 24).

Szommer, K., Balogh, Z., \& Racskó, P. (2014). Az online világban hagyott virtuális lábnyomokban rejlő információ és azok veszélyei. Vezetéstudomány.

Voulodimos , A. S., \& Patrikakis , C. Z. (2009. december). Quantifying privacy in terms of entropy for context aware services. Identity in the Information Society, 2(2), 155-169. 
Witten, I. H., Frank, E., \& Hall, M. A. (2011). Data Mining - 3rd edition. Burlington: Morgan Kaufmann.

Wolf, R., Nemeslaki, A., \& Sasvári, P. (2015). Old Monarchy in the New Cyberspace: Empirical Examination of Information Security Awareness among Austrian and Hungarian Enterprises. Academic and Applied Research in Military and Public Management Science, 63-78.

Xu, H., Dinev, T., \& Smith, J. H. (2011). Information privacy research: An interdisciplinary review. MISQ, Volume 35, Issue 4, 989-1015.

Youyou, W., Kosinki, M., \& Stillwell, D. (2015. január 27). Computer-based personality judgments are more accurate than those made by humans. PNAS, old.: 1036-1040.

\subsubsection{Hírek és cikkek}

Adobe. (2011. július). Adobe. Letöltés dátuma: 2013. augusztus 25, forrás: Macromedia Flash and Shockwave Players: Macromedia Flash and Shockwave Players

Adobe. (2011. július). Adobe. Letöltés dátuma: 2013. augusztus 10, forrás: Adobe Flash Platform runtimes / Statistics : PC penetration: http://www.adobe.com/mena_en/products/flashplatformruntimes/statistics.ht $\underline{\mathrm{ml}}$

Alessandro, A. (2013. június). TED. Forrás: What will a future without secrets look like?: http://www.ted.com/talks/alessandro acquisti why privacy matters

Alexander, D. (2012. augusztus 24). Scatmania - The adventures and thoughts of "Scatman" Dan Q. Letöltés dátuma: 2013. július 27, forrás: Visitor Tracking Without Cookies (or How To Abuse HTTP 301s): http://www.scatmania.org/2012/04/24/visitor-tracking-without-cookies/

Ali, R. (2010. július 13). Hasseg.org. Forrás: Getting a List of Installed Fonts with Flash and Javascript: http://hasseg.org/blog/post/526/getting-a-list-ofinstalled-fonts-with-flash-and-javascript/

All About Cookies. (2011. május 26). Cookies - Free Cookie Resources. Letöltés dátuma: 2013. augusztus 11, forrás: Welcome To All About Cookies.org: http://www.allaboutcookies.org/ 
Andersen, A. (2008. szeptember 3). History of the browser user-agent string. Forrás: WebAIM - Web Accessibility in Mind: http://webaim.org/blog/user-agentstring-history

Berners-Lee, T. (2014. március). TED. Forrás: A Magna Carta for the web: http://www.ted.com/talks/tim_berners_lee_a_magna_carta_for_the_web?lang uage $=$ en\#t-47545

Bhavin, R. (2014. május 6). PHP And MySQL Training In Vadodara With Live Project. Forrás: Joomla Training In Vadodara: http://dotnettrainingvadodara.blogspot.hu/

Brafton Editorial. (2013. május 28). Brafton - Fuel your brand. Letöltés dátuma: 2013. augusztus 25, forrás: Teens' data sharing attitudes make audience targeting easier: http://www.brafton.com/news/teens-data-sharing-attitudes-makeaudience-targeting-easier

Built With. (2013. augusztus). Built With. Letöltés dátuma: 2013. augusztus 31, forrás: OpenID Usage Statistics: http://trends.builtwith.com/docinfo/OpenID

Camilla, T. (2015. március 27). Facebook completes first drone flight above UK, Mark Zuckerberg confirms. Forrás: The Telegraph: http://www.telegraph.co.uk/news/media/11499142/Facebook-completes-firstdrone-flight-above-UK-Mark-Zuckerberg-confirms.html

Chaffey, D. (2015. április 21). Display advertising clickthrough rates. Forrás: Smart Insights: $\quad$ http://www.smartinsights.com/internet-advertising/internetadvertising-analytics/display-advertising-clickthrough-rates/

Chen, A. (2011. július 27). Gawker. Letöltés dátuma: 2011. november 20, forrás: Mark Zuckerberg's Sister: 'I Think Anonymity on the Internet Has to Go Away': http://gawker.com/5825343/mark-zuckerbergs-sister-i-think-anonymity-onthe-internet-has-to-go-away

Christina, F. (2013. december 27). 'Facebook is simply not cool anymore' to teens, study finds. Letöltés dátuma: 2014. március 30, forrás: VentureBeat: http://venturebeat.com/2013/12/27/facebook-is-simply-not-cool-anymore-toteens-study-finds/

Cisco. (2014. június 10). Cisco. Forrás: The Zettabyte Era-Trends and Analysis: http://www.cisco.com/c/en/us/solutions/collateral/service-provider/visualnetworking-index-vni/VNI_Hyperconnectivity_WP.html 
D. Blondel, V., A. Hidalgo, C., Verleysen, M., \& de Montjoye, Y.-A. (2013, march 25). Scientific Reports. Retrieved may 4, 2013, from Unique in the Crowd: The privacy bounds of human mobility: http://www.nature.com/srep/2013/130325/srep01376/full/srep01376.html

Dan, C. (2004. szeptember 1). Hypertext Transfer Protocol -- HTTP/1.1 - Method definitions. Letöltés dátuma: 2013. július 14, forrás: World Wide Web Consortium (W3C): http://www.w3.org/Protocols/rfc2616/rfc2616-sec9.html eNet. (2013). Jelentés az internetgazdaságról. Budapest.

Facebook Developers. (2013. július 12). Facebook Developers. Letöltés dátuma: 2013. július 15, forrás: Permissions: https://developers.facebook.com/docs/facebook-login/permissions/

Falkvinge, R. (2013. october 2). Privacy Online News - Protect Your Privacy. Forrás: How Does Privacy Differ From Anonymity, And Why Are Both Important?: https://www.privateinternetaccess.com/blog/2013/10/how-does-privacydiffer-from-anonymity-and-why-are-both-important/

Gary, K. (2012. február). TED. Forrás: Nyomon követni a nyomkövetôket: http://www.ted.com/talks/gary_kovacs_tracking_the_trackers?language=hu\#t $\underline{-368530}$

Halász, B. (2014. november 24). Az EU új adatvédelmi rendelete - Jön! Jön. Jön? Forrás: Twobirds ideas Hungary - A Bird \& Bird blog: http://twobirdsideas.hu/2014/11/24/az-eu-uj-adatvedelmi-rendelete-jon-jonjon/

Halász, B. (2016. május 4). 2018. május 25-étól kell alkalmazni az EU új adatvédelmi rendeletét! Letöltés dátuma: 2017. március 26, forrás: Twobirds ideas Hungary - A Bird \& Bird blog: https://twobirdsideas.hu/2016/05/04/2018-majus-25etol-kell-alkalmazni-az-eu-uj-adatvedelmi-rendeletet/

Hallen, E. (2012. február 4). Quora. Forrás: How many friends does a Facebook user have on average, and what is the distribution of friends numbers?: https://www.quora.com/How-many-friends-does-a-Facebook-user-have-onaverage-and-what-is-the-distribution-of-friends-numbers

Healy, B. (2015. június 15). People voted on a Magna Carta for the Internet and here's what they want. Forrás: Mashable: http://mashable.com/2015/06/15/magnacarta-digital-age-internet/\#3EImqMRDfkqw 
Heggestuen, J. (2013. december 15). Business Insider. Forrás: One In Every 5 People In The World Own A Smartphone, One In Every 17 Own A Tablet: http://www.businessinsider.com/smartphone-and-tablet-penetration-2013-10

Hobson, A. (2013. február 15). Facebook tracks data from users who have logged out. Letöltés dátuma: 2013. július 7, forrás: The Daily Caller: http://dailycaller.com/2013/02/15/facebook-tracks-data-from-users-whohave-logged-out/

JanRain. (2013). JanRain - Registration is hard. We make it easy. Letöltés dátuma: 2013. augusztus 31, forrás: JanRain Engage - Social Login \& Share: http://janrain.com/

Kozma, Z. (2015. augusztus 5). Még idén elfogadhatják az EU új adatvédelmi rendeletét. Forrás: Advocatus - A DLA Piper jogi blogja: http://blogs.dlapiper.com/advocatus/?p=1692

Lohr, S. (2009. szeptember 21). A \$1 Million Research Bargain for Netflix, and Maybe a Model for Others. Letöltés dátuma: 2017. február 19, forrás: The New York Times:

http://www.nytimes.com/2009/09/22/technology/internet/22netflix.html?_r=0

Mathews, L. (2013. március 5). Geek.com. Letöltés dátuma: 2013. augusztus 17, forrás: The state of Do Not Track in web browsers: http://www.geek.com/news/the-state-of-do-not-track-in-web-browsers$\underline{1541614 /}$

Medic, M. (2014. április 7). Creating and using CRUD stored procedures. Forrás: SQLShack: http://www.sqlshack.com/creating-using-crud-stored-procedures/ Mozilla.org. (dátum nélk.). Mozilla.org. Letöltés dátuma: 2013. augusztus 17, forrás: Do Not Track: http://www.mozilla.org/en-US/dnt/

NetMarketShare. (2016. december). NetMarketShare. Letöltés dátuma: 2017. január 1, forrás: Desktop Operating System Market Share: http://www.netmarketshare.com/operating-system-marketshare. aspx?qprid=10\&qpcustomd $=0$

OpenID. (2015). OpenID. Forrás: OpenID: http://openid.net/

Owen, J. (2014. march 12). The Independent. Forrás: 25 years of the World Wide Web: Tim Berners-Lee explains how it all began: http://www.independent.co.uk/life-style/gadgets-and-tech/news/25-years-of- 
the-world-wide-web-the-inventor-of-the-web-tim-bernerslee-explains-how-itall-began-9185040.html

Pariser, E. (2011. március). Beware online "filter bubbles". Forrás: TED.com: http://www.ted.com/talks/eli pariser beware online filter bubbles

Parker, N. (2012. április 30). NBNCo - Bringing broadband to lif. Letöltés dátuma: 2013. augusztus 10, forrás: How many net-connected devices are in your home?: http://www.nbnco.com.au/blog/how-many-net-connected-gadgets-inyour-home.html

Rosenbush, S. (2013. október 30). Facebook Tests Software to Track Your Cursor on Screen. Forrás: Wall Street Journal: http://blogs.wsj.com/digits/2013/10/30/facebook-considers-vast-increase-indata-collection/

Salesforce. (2013. június). The Facebook Ads Benchmark Report. Forrás: Salesforcesocial.com: $\quad$ http://www.salesforcemarketingcloud.com/wpcontent/uploads/2013/06/The-Facebook-Ads-Benchmark-Report.pdf

Sam, O. (2015. február 13). Stanford researchers develop method for tracking mobile devices using battery charge data. Forrás: Apple Insider: http://appleinsider.com/articles/15/02/23/stanford-researchers-develop$\underline{\text { method-for-tracking-mobile-devices-using-battery-charge-data }}$

Shadmand, S. (2013. október 9). Socialize. Forrás: Everything you need to know about iOS's IDFA, IDV \& Cookies Overview: http://blog.getsocialize.com/2013/everything-you-need-to-know-about-iossidfa-idv-cookies-overview

Shall, B. (2017). Useragent String Lookup. Forrás: UseragentAPI: https://useragentapi.com/

Smart, J. (2013. december 17). James Smart személyes Twitter oldala. Letöltés dátuma: 2017. április 29, forrás: Twitter: https://twitter.com/jamessmat/status/412920722407686145

Smith, C. (2015. november 13). By the Numbers: 200+ Amazing Facebook Statistics (November 2015). Forrás: DMR - Digital Marketing Stats/Strategy/Gadgets: http://expandedramblings.com/index.php/by-the-numbers-17-amazingfacebook-stats/

Stack Exchange. (2011. november 9). Stack Exchange. Forrás: Can web sites detect whether you are using private browsing mode? 
http://security.stackexchange.com/questions/9037/can-web-sites-detectwhether-you-are-using-private-browsing-mode

Stanclift, M. (2008. szeptember 10). A quick look at browser engines. Forrás: Jinson Joseph Elayidom - My Musings: https://getjins.wordpress.com/2008/09/10/aquick-look-at-browser-engines-trident-gecko-webkit-presto/

Statista - The Statistics Portal. (2015). Statista - The Statistics Portal. Forrás: Average number of Facebook friends of users in the United States as of February 2014, by age group: http://www.statista.com/statistics/232499/americans-who-usesocial-networking-sites-several-times-per-day/

Statistic Brain. (2014. január 1). Statistic Brain. Letöltés dátuma: 2014. március 18, forrás: Facebook statistics: http://www.statisticbrain.com/facebook-statistics/ Tapad. (2013). Unify Life Across Devices. Forrás: Tapad: http://www.tapad.com The Onion Router. (2015. december 10). The Onion Router. Forrás: Tor: Overview: https://www.torproject.org/about/overview.html.en

The Psychometrics Centre. (2013). Apply Magic Sauce - Prediction API. Forrás: University of Cambridge - The Psychometrics Centre: http://applymagicsauce.com/you.html

The Stanford Review. (2014. május 2). The Stanford Review - Stanford's Independent Newspaper. Forrás: Starting today, Yahoo will not honor Do Not Track settings: $\quad$ http://stanfordreview .org/article/starting-today-yahoo-will-nothonor-do-not-track-settings/

Twitter Bootstrap. (2014. november 12). Twitter Bootstrap. Forrás: CSS: http://getbootstrap.com/css/\#grid-media-queries

Vincenzo, C. (2016. január). VincosBlog. Letöltés dátuma: 2016. április 10, forrás: World Map of Social Networks: http://vincos.it/world-map-of-socialnetworks/

W3Schools. (2016. november). Browser Display Statistics. Letöltés dátuma: 2017. január $\quad 1, \quad$ forrás: W3Schools: http://www.w3schools.com/browsers/browsers_display.asp

Websiteoptimization.com. (2009. február 19). Anatomy of an HTTP request and correlation to Pagetest legend. Forrás: Websiteoptimization.com: http://www.websiteoptimization.com/secrets/metrics/10-21-http-request.html

Yahoo Privacy Team. (2014. április 30). Yahoo's Default $=A$ Personalized Experience. Forrás: Yahoo! Global Public Policy: 
http://yahoopolicy.tumblr.com/post/84363620568/yahoos-default-apersonalized-experience

Zawadziński, M. (2013, april 26). Ad Technology and Analytics. Retrieved may 12, 2013, from Alternatives to cookie tracking: http://zawadzinski.com/2013/04/26/alternatives-to-cookie-tracking/

Zephora - Digital Marketing. (2017. március 7). The Top 20 Valuable Facebook Statistics - Updated March 2017. Forrás: Zephora - Digital Marketing: https://zephoria.com/top-15-valuable-facebook-statistics/

Zuckerberg, M. (2015. március 25). 2015 Opening keynote. Forrás: Facebook Developer Conference: https://fbf8.com/ 